NBER WORKING PAPER SERIES

\title{
EXECUTIVE COMPENSATION IN AMERICA: OPTIMAL CONTRACTING OR EXTRACTION OF RENTS?
}

\author{
Lucian Arye Bebchuk \\ Jesse M. Fried \\ David I. Walker \\ Working Paper 8661 \\ http://www.nber.org/papers/w8661 \\ NATIONAL BUREAU OF ECONOMIC RESEARCH \\ 1050 Massachusetts Avenue \\ Cambridge, MA 02138 \\ December 2001
}

\begin{abstract}
Although this paper has been long in the making, it remains a work in progress. We welcome any comments, including about work by others that would be worthwhile noting on treating differently. We have benefited from the valuable suggestions of various individuals including Victor Brudney, Brian Cheffins, Jeff Gordon, Louis Kaplow, Marcel Kahan, Reinier Kraakman, Assaf Hamdani, Sharon Hannes, Michael Levine, Steve Shavell, David Yermack and participants in two seminars at Harvard. Nicholas Hecker, Matthew Heyn, Ryan Kantor, Jason Knott, and Matthew McDermott provided excellent research assistance. For financial support, we wish to thank the John M. Olin Center for Law, Economics, and Business at Harvard Law School, the Berkeley Committee on Research, and the Boalt Hall Fund. Future revisions of this paper may be retrieved from www.law.harvard.edu/faculty/bebchuk. The views expressed herein are those of the authors and not necessarily those of the National Bureau of Economic Research.
\end{abstract}

(C) 2001 by Lucian Arye Bebchuk, Jesse M. Fried and David I. Walker. All rights reserved. Short sections of text, not to exceed two paragraphs, may be quoted without explicit permission provided that full credit, including $\odot$ notice, is given to the source. 
Executive Compensation in America: Optimal Contracting or Extraction of Rents?

Lucian Arye Bebchuk, Jesse M. Fried and David I. Walker

NBER Working Paper No. 8661

December 2001

JEL No. D23, G32, G34, G38, J33, J44, K22, M14

\begin{abstract}
$\underline{\text { ABSTRACT }}$
This paper develops an account of the role and significance of rent extraction in executive compensation. Under the optimal contracting view of executive compensation, which has dominated academic research on the subject, pay arrangements are set by a board of directors that aims to maximize shareholder value by designing an optimal principal-agent contract. Under the alternative rent extraction view that we examine, the board does not operate at arm's length; rather, executives have power to influence their own compensation, and they use their power to extract rents. As a result, executives are paid more than is optimal for shareholders and, to camouflage the extraction of rents, executive compensation might be structured sub-optimally. The presence of rent extraction, we argue, is consistent both with the processes that produce compensation schemes and with the market forces and constraints that companies face. Examining the large body of empirical work on executive compensation, we show that the picture emerging from it is largely compatible with the rent extraction view. Indeed, rent extraction, and the desire to camouflage it, can better explain many puzzling features of compensation patterns and practices. We conclude that extraction of rents might well play a significant role in U.S. executive compensation; and that the significant presence of rent extraction should be taken into account in any examination of the practice and regulation of corporate governance.
\end{abstract}

Lucian Arye Bebchuk

Harvard Law School

1557 Massachusetts Avenue

Cambridge, MA 02138

and NBER

bebchuk@law.harvard.edu
Jesse M. Fried

Boalt Hall School of Law

University of California

Berkeley, CA 94720
David I. Walker

Ropes \& Gray

Boston, MA

and Harvard Law School 


\section{TABLE OF CONTENTS}

I. INTRODUCTION..................................................... 1

II. Alternative VieWs of THE EXeCUtive Compensation Process........ 7

A. $\quad$ The Optimal Contracting View................................. 8

1. Inducing the Executive to Take and Retain Position ........... 9

2. Provision of Incentives................................... 10

3. Costs.................................................. 10

B. Critique of the Optimal Contacting View........................ 11

1. Limitations on Arm's Length Model of Boards................

(a) Management Control over Director

Appointment......................................... 14

(b) Board Dynamics.................................. 15

(c) Insufficient Incentives.............................. 18

(d) Information Disparities............................. 20

2. Limitations on the Power of Market Forces.................... 21

(a) Managerial Labor Markets.......................... 22

(b) Market for Corporate Control........................ 25

(c) Market for Additional Capital........................ 26

(d) Product Markets...................................... 27

(e) Overall Force......................................... 27

3. The Practical Absence of Judicial Review.................... 28

C. The Rent Extraction View................................... 31

1. Power and Rents......................................... 31

2. The "Outrage Constraint" ................................ 32

3. The Critical Role of "Camouflage" .......................... 34

4. More and Less Power................................... $\quad 35$

D. Conforming to Norms........................................ 36

III. THE COMPENSATION LANDSCAPE AS SEEN BY THE TWO VIEWS 38

A. The Use of Executive Stock Options............................. 39

1. Using Options as Part of Optimal Contracting............... 40

2. Using Options to Extract Rent............................ 41

3. Possible Objections to the Rent Extraction View of Options... 43

B. The Use of Compensation Consultants.......................... 46

1. Using Consultants to Search for Optimal Arrangements...... 46

2. Using Consultants to Legitimize Compensation Arrangements.............................................. 47 
C. The Limited Fraction of Value Paid to Executives..................

1. Claims that Executives Receive too Small a Fraction of Value.

2. Defense of Existing Levels by Supporters of Optimal Contracting.

3. The Rent Extraction Perspective............................

IV. EVIDENCE BETTER EXPLAINED BY RENT EXTRACTION..................... 51

A. Rewarding Executives for General Market Rises................. 51

1. The Benefits of (some form of) Indexing..................... 53

2. Optimal Contracting Explanations.......................... 57

3. Is there an Accounting Constraint on Indexing?............... 62

4. The Rent Extraction Explanation for Not Indexing............ 66

5. Implicit Relative Performance Evaluation.................... 67

B. Uniform Use of At-the-Money-Option......................... 69

1. The Puzzle for the Optimal Contracting View................ 69

2. The Rent Extraction Explanation...........................

C. Resetting of Option Exercise Prices............................ 73

1. The Resetting Puzzle....................................... 73

2. The Rent Extraction Explanation......................... 75

D. Executives' Broad Freedom to Unwind Incentives................ 76

E. Reload Options............................................. 80

F. Differences between Executives with More and Less Power........ 84

G. Differences between U.S and Non-U.S. Companies.............. 88

V. CONCLUSION............................................................ 91

REFERENCES........................................................... R-1 


\section{INTRODUCTION}

Executive compensation has for long attracted a great deal of attention from academics, the media, Congress, and the public at large. In the United States, total executive pay increased dramatically in the 1990s, as the stock option programs adopted by companies yielded unprecedented gains for senior executives during the extended bull market. ${ }^{1}$ These gains were accompanied by a parallel rise in academic work on the subject. ${ }^{2}$ Indeed, it appears that the rate of growth in such academic work has outpaced even the growth rate of executive compensation levels. ${ }^{3}$

This paper questions the dominant view in the academic work on executive compensation. It also seeks to put forward a systematic and comprehensive account of an alternative view of executive compensation, the "rent extraction" view. This view, we argue, is suggested by a realistic analysis of the processes that produce executive pay and is consistent with the substantial body of empirical evidence on executive compensation. Indeed, the rent extraction view can better explain significant features of the executive compensation landscape, including ones that have been long regarded as puzzling.

The dominant view of executive compensation among academics has for some time been what we call "the optimal contracting view." 4 Under this

1 The median compensation of S\&P 500 CEO's increased by approximately 150\% from 1992 to 1998, and option-based compensation provided the largest share of the gains. See Tod Perry and Marc Zenner, CEO Compensation in the 1990's: Shareholder Alignment or Shareholder Expropriation?, 35 WAKE FOREST L. REV. 123, at Table 1 (2000).

2 Recent surveys of this voluminous literature include Perry and Zenner, supra note 1; John M. Abowd and David S. Kaplan, Executive Compensation: Six Questions that Need Answering, 13 J. ECON. PERSPECTIVES 145 (1999); and Kevin J. Murphy, Executive Compensation, in Handbook of Labor Economics (Orley Ashenfelter and David Card eds., 1999). A noteworthy survey from an earlier era is Michael Jensen and J. Zimmerman, Management Compensation and the Managerial Labor Market, 7 J. ACCT. \& ECON. 3 (1985).

3 See Kevin J. Murphy, Executive Compensation, in Handbook of Labor Economics (Orley Ashenfelter and David Card eds., 1999). He demonstrates graphically that the increase in academic papers on the subject of CEO pay outpaced the increase in total CEO pay during the late 1980s and early 1990s.

4 This is the leading view among financial economists, who have done most of the scholarship in this area. Indeed, as we see later in the paper, there is a large body of work in financial economics that seeks to explain all of the features of the executive compensation landscape within an optimal contracting framework. The optimal contracting view also forms the basis for an important line of legal scholarship. See, e.g., Daniel R. Fischel, The Corporate Governance Movement, 35 VAND. L. REV. 1259 (1982); Frank H. Easterbrook, Managers' Discretion and Investors' 
view, executive compensation practices in large, publicly traded companies are designed to minimize the agency costs that exist between the senior executives, the agents, and the shareholders, the principals. The board is viewed as seeking to maximize shareholder value and the compensation scheme is designed to serve this objective. Financial economists, both theorists and empiricists, have largely worked within this model in attempting to explain the various features observed in executive compensation programs as well as the cross-sectional variation in compensation practices among firms.

We seek to contrast this optimal contracting view of executive compensation with an alternative perspective that we label "the rent extraction view." The rent extraction view focuses on the ability of executives to influence the pay process for their own gain at the expense of the shareholders. Under this view, boards do not adopt optimal compensation arrangements, because directors are captured by management, sympathetic to them, or simply ineffectual in overseeing compensation. As a result, executives receive pay in excess of the level that would be optimal for shareholders, and this excess pay constitutes rent. ${ }^{5}$ Although this rent extraction view lies at the heart of much of the public outcry over compensation levels and practices, it has received little attention and development in the academic literature. ${ }^{6}$

Welfare: Theories and Evidence, 9 DEL. J. CORP. L. 540, 540-571 (1984); Robert Thomas, Is Corporate Executive Compensation Excessive? in THE ATTACK ON CORPORATE AMERICA 276 (M. Bruce Johnson ed. 1978); Nicholas Wolfson, A Critique of Corporate Law, 34 U. MiAMI L. REV. 959 (1980).

5 Executives can extract rent in ways other than their executive compensation schemes. See, e.g., Lucian Arye Bebchuk and Christine Jolls, Managerial Value Diversion and Shareholder Wealth, 15 J. L. ECON. \& ORG. 487 (1999); Jesse M. Fried, Reducing the Profitability of Corporate Insider Trading through Pretrading Disclosure, 71 S. CAL. L. REV. 303 (1998); Jesse M. Fried, Insider Signaling and Insider Trading with Repurchase Tender Offers, 67 U. CHI. L. REV. 421 (2000). And it is possible to define compensation schemes as including benefits that managers obtain in any way as a result of their position, including benefits from insider trading, taking of opportunities, and so forth. In this paper, however, our focus is solely on the benefits that executives get, and the rent they extract, from arrangements that are formally defined and ordinarily viewed as compensation arrangements.

6 Although many practitioners (see, e.g., GRAEF S. CRYSTAL, IN SEARCH OF EXCESS (1991)) and media commentators express views which are close to the view we put forward more systematically in this work, academics commonly hold what we have called the "optimal contracting" view. See supra note 4 and sources cited therein.

There is some academic work that is close in spirit to ours. A number of legal scholars have expressed skepticism about the claim that executive compensation arrangements are designed to maximize shareholder value. See, e.g., Linda J. Barris, The Overcompensation Problem: A Collective Approach to Controlling 
The view that executives can extract rents does not imply that there are no constraints on their ability to do so. One important force in this respect is what we call the "outrage constraint." Directors would be reluctant to approve, and managers hesitant to propose, pay plans that would seem outrageous to observers. Such plans would therefore embarrass the directors and executives or reduce the willingness of shareholders to vote with management in future control contests. The nature of the constraints on the process implies that executives would have an interest in camouflaging the presence of rent extraction and concealing its magnitude. Executives thus would tend to prefer compensation structures and processes that enable them to do so. According to the rent extraction view, this desire to camouflage rent extraction has an important influence on the design of compensation practices and is a key concept for understanding existing practices.

Although the rent extraction view is conceptually quite different from the optimal contracting view, the two are not mutually exclusive, and common executive compensation practices might reflect a mix of rent extraction and incentive generation. The rent extraction view does not suggest that no part of the compensation scheme serves shareholders' interests. It only argues that rent extraction plays an important role in compensation arrangements and that, as a result, managers are paid more than is optimal and are paid in ways that are not necessarily optimal for shareholders.

Our analysis indicates that, indeed, rent extraction is likely to play a significant role in U.S. executive compensation and that rent extraction provides an important explanation for many executive compensation practices and patterns. As a theoretical matter, we argue that the process of setting compensation is consistent with the extraction of rents by executives. As an empirical matter, we argue that the extensive empirical evidence compiled by proponents of the optimal contracting view is consistent with

Executive Pay, 68 IndianA LAW JOURNAL 59 (1992); Mark J. Lowenstein, Reflections on Executive Compensation and a Modest Proposal for Reform, 50 S.M.U. L. REV. 201 (1996); Detlev Vagts, Challenges to Executive Compensation: For the Markets or the Courts?, 8 J. CORP. L. 231 (1983); Carl T. Bogus, Excessive Executive Compensation and the Failure of Corporate Democracy, 41 BUfF. L. REV. 1 (1993); Charles M. Yablon, Bonus Questions-Executive Compensation in the Era of Pay for Performance, 75 NOTRE DAME L. REV. 271 (1999). And several empirical papers by financial economists have recently suggested that certain of their findings are consistent with, or indicative of, "appropriation" or "skimming" by executives. Part IV.E infra discusses such studies by Bertrand and Mullainathan, Benz, Kucher, and Stutzer, and Yermack. No work, however, has thus far attempted to put forward a full account of an alternative to the optimal contracting view -- including both a theoretical framework for such an alternative view and an examination in light of this view of the empirical literature on executive compensation -- as we aim to do in this paper. 
the rent extraction view, and that, furthermore, important pieces of this evidence are better explained by the rent extraction view.

We start by presenting in Part II the theoretical structure of the two alternative views of executive compensation. We begin by providing an account of the optimal contracting view of executive compensation, and we discuss the elements and features that one would expect to find in an optimal compensation contract. We next offer a critique of the optimal contracting view. Optimal compensation contracts could result either from effective arm's length bargaining between the board and the executives or from market constraints that induce players to adopt such contracts even in the absence of arm's length bargaining. Our critique indicates that neither phenomenon can be expected to constrain executive compensation effectively. Rather, because bargaining is in fact not at arm's length, and because market forces are not sufficiently strong to require the adoption of optimal compensation contracts, executives can be expected to secure contracts that provide them with significant rent.

After analyzing the problems with the optimal contracting view, we turn to providing an account of the alternative rent extraction view of executive compensation. The very reasons for questioning the optimal contracting view also suggest that executives will have substantial influence over their own pay and thus significant power to extract rents. These reasons also suggest that the greater managers' power, the greater their ability to extract rents.

Two important building blocks in the rent extraction view are the "outrage constraint" and "camouflage." Although directors would acquiesce in management rent extraction to a certain point, they would draw the line at practices so outrageous as to cause them embarrassment or sully their reputation, and both directors and management might wish to refrain from choices that would increase the likelihood of ouster. Because outrage resulting from outsiders' recognition of the presence of rent extraction provides an important constraint on compensation under this model, choices intended to obfuscate and legitimize - or, more generally, to camouflage play a significant role in the design of compensation arrangements. This key concept of camouflage will turn out to be quite useful in explaining many of the patterns and puzzles provided by the executive compensation landscape. We conclude Part II by considering the role of conformity to norms, and how this phenomenon can play a role under either an optimal contracting view or a rent extraction view.

We then turn to a detailed examination, in light of the two alternative views, of the vast empirical literature on executive compensation. Part III starts this examination by focusing on those main features of the executive compensation landscape that are consistent with both views. These features include the increasing use of executive stock options over the past two 
decades, the use of compensation consultants and surveys, and the limited fraction of incremental corporate value transferred to executives. We show, for example, that the extensive use of compensation consultants can be seen as an attempt to optimize incentives under the optimal contracting view or as a means of justifying and legitimizing pay under the rent extraction view.

Part IV points out a significant number of compensation practices and patterns which can be better explained by the rent extraction view and thus suggest the presence of rent extraction. Most of the practices and features that we analyze in this Part are ones that have long been regarded as puzzles by researchers working within the optimal contracting view. These puzzles, we argue, can be better explained by the rent extraction view. We first turn to firms' failure to filter out industry or broader market stock price effects by using some form of indexing or benchmarking. The lack of such filtering means that executives are rewarded for share price increases even when those increases are purely a function of economy-wide and sector changes that are beyond their control. As a result, even poorly performing managers can make significant profits when option compensation is based on changes in the absolute share price. The substantial compensation dollars that are spent on rewarding managers for general market rises could be either used to enhance incentives (by, for example, giving managers a larger number of indexed options) or saved.

As we show, the almost complete absence of indexing in option programs is rather difficult to explain from an optimal contracting perspective. We explore the range of possible ways to filter out general market rises and show how unlikely it is that no form of filtering is ever optimal. We also argue that the accounting considerations that are used to justify non-indexing are likely to be of little importance in at least some cases, and in any event could probably be avoided by designing the filtering scheme in certain ways.

The absence of any filtering of general-market or industry effects is not puzzling, however, from the rent extraction perspective. On this view, compensation schemes are often designed with an eye to maximizing executive pay while staying within the range of legitimacy and acceptability. Given that the use of regular options is well-established and generally considered a legitimate form of compensation, and that indexing might serve shareholders' interests but reduce managers' benefits, the lack of any movement toward some form of indexing is consistent with the rent extraction view.

Part IV next considers the near-uniform use of at-the-money options. An optimally designed option scheme would seek to provide risk-averse managers with the strongest cost-effective incentives to exert effort and make value-maximizing decisions. The optimal exercise price under such a scheme should depend on various factors that might differ from executive to executive, from company to company, and from time to time, including the 
degree of managerial risk aversion (which in turn might be affected by the manager's age and wealth), the project choices available to the firm, the volatility of the company's stock, the expected rate of inflation, and the length of the contract. There is thus no reason to expect that the same exercise price formula would be optimal for all executives at all firms in all industries at all times. Thus, the fact that options are almost uniformly issued at-the-money is rather difficult to explain from an optimal contracting perspective.

However, the uniform use of at-the-money-options is not puzzling from the rent extraction perspective. From this perspective, given that executives benefit from lower exercise prices, there will be a desire to push exercise prices to the lowest level possible without crossing the outrage constraint. There is no reason for designers of plans to seek to raise the exercise prices above the market price at the time the options are issued, given that some justification is available for at-the-money-options. The only things to avoid is giving in-the-money-options which might be regarded as a windfall and whose grant might undermine the accounting justification for avoiding indexed compensation schemes.

Another puzzle for optimal contracting is managers' widespread freedom to unwind their incentives. An optimal principal-agent contract can be expected to place some constraints on managers' ability to sell stock or hedge the stock options given to them in order to better align their interests with those of shareholders. However, aside from vesting requirements such restrictions are almost never imposed. Thus, executives usually sell existing shares when granted options or restricted stock, exercise options well before expiration, immediately sell the shares they acquire upon exercise of options, and seek to hedge their exposure when disposal is not possible.

The lack of such restrictions, while difficult to explain from an optimal contracting perspective, is consistent with rent extraction. Under this view, compensation plans are designed with managers' welfare in mind. The rent extraction view thus predicts that designers of compensation plans would avoid adding restrictions on unwinding, which might well serve shareholders but which would reduce managers' benefits.

Part IV also examines the phenomena of option repricing and reloadable options. Repricing refers to the lowering of the options' strike price when the stock price falls below the original exercise price, a practice that has recently become increasingly common. The possibility that the exercise price will be lowered ex post if the stock price does not do well dilutes ex ante incentives. To be sure, such downward repricing can in theory be useful going forward in order to retain and to provide incentives to good managers when the stock price falls for reasons beyond managers' control. However, the empirical data suggest that these repricings are, at least in part, designed to provide executives with extra value beyond what is necessary for retaining them. 
Reloadable option plans are option programs under which an executive exercising options by giving the firm shares that he already owns receives a new option for each share tendered with the same expiration date as the old options. These plans allow executives to profit from share price volatility even if the long-term share performance is flat, and to do so in a way that is difficult for shareholders to understand. The only possible justification that can be given for reloadable options is that - given executives' freedom to unwind incentives - it might be desirable to have a mechanism that will replenish those incentives. But this problem could have been, of course, more easily and effectively addressed by placing some limits on executives' freedom to unwind incentives. The puzzling combination of complete freedom to unwind incentives and reloading options aimed to correct it, we argue, can best be explained by the rent extraction view.

Finally, we show in Part IV that the rent extraction perspective can help explain cross-company as well as cross-country differences in executive pay. The rent extraction view predicts that managers will be able to pay themselves relatively more in firms in which they have relatively more power. This is, we show, the case. Surveying the empirical literature, we find that in the U.S. CEO pay is higher in firms where the CEO is more powerful vis-à-vis the board, in firms with anti-takeover provisions, in firms where the institutional investor presence is smaller, and in firms where there is no large shareholder.

Furthermore, the shareholders of U.S. firms are typically more dispersed than the shareholders of firms in other developed countries. Thus, rent extraction can also explain why U.S. managers tend to be paid more than their counterparts in similar countries.

The conclusion that rent extraction plays a significant role in executive compensation has important implications for the study, regulation, and practice of corporate governance. We expect to explore fully these implications in subsequent work. Here, however, we focus on a prior and important step - to put forward a systematic framework for the study of rent extraction in executive compensation, and to show that the evidence is consistent with and supportive of the view that rent extraction plays an important role in executive compensation.

\section{Alternative Views OF the EXECUtive COMPENSATION PROCESS}

Our analysis focuses on public companies that lack a controlling shareholder. Managers of these companies have substantial power and discretion but generally own only a small fraction of the firm's equity of the 
firm. ${ }^{7}$ The interests of the shareholder-principals and manager-agents are not perfectly convergent, and thus there exists an agency problem. The two views of executive compensation that we discuss both start with the recognition that there is an agency problem, but they take that recognition in different directions.

Section A presents the more conventional view among academics that executive compensation is one of the instruments that the board uses in the shareholders' interest to check the agency problem. In Section B we put forward a critique of this view. An optimal principal-agent contract would be chosen if (i) the board were bargaining with the executives at arm's length; (ii) the directors or executives were constrained by market forces from deviating from optimal compensation contracts; or (iii) shareholders could use the courts to force managers to adopt compensation contracts that maximize shareholder value. We argue in Section B that none of these propositions holds, providing reasons to doubt whether the optimal contracting view fully describes the executive compensation landscape. Section C puts forward an alternative view - rent extraction - under which executive compensation is seen as part of the agency problem rather than a solution to it. Section D concludes by considering the implications of the norms literature for our examination of executive compensation.

\section{A. The Optimal Contracting View}

There is no contract that would perfectly align the interests of managers and shareholders. The optimal contract is therefore the one that minimizes agency costs, that is, the sum of contracting, monitoring, other expenditures made in achieving a certain level of compliance with the principal's interest and the costs of the residual divergence. ${ }^{8}$ Under the optimal contracting view, this is exactly what executive compensation packages are designed to do. The board, attempting to maximize

7 In 1996, for example, the average CEO of S\&P 500 manufacturing companies owned less than $1 \%$ of company shares, while median ownership was only $0.11 \%$. See Murphy, supra note 3 .

8 Thorough review of the optimal contracting literature is beyond the scope of this paper. Important works on the subject include J. A. Mirrlees, The Optimal Structure of Incentives and Authority within an Organization, 7 BELL. J. ECON. 105 (1976); Dilip Mookherjee, Optimal Incentive Schemes with Many Agents, 51 REV. ECON. STUD. 433 (1984); Stephen A. Ross, The Economic Theory of Agency: The Principal's Problem, 63 AMER. ECON. REV. 134 (1973); Bengt Holmstrom, Moral Hazard and Observability, 10 BELL. J. ECON. 74 (1979); Bengt Holmstrom, Moral Hazard in Teams, 13 BELL. J. ECON. 324 (1982); Sanford J. Grossman and Oliver D. Hart, An Analysis of the Principal-Agent Problem, 51 ECONOMETRICA 7 (1983); and Robert Gibbons, Incentives and Careers in Organizations, in ADVANCES IN ECONOMIC THEORY AND ECONOMETRICS 1 (D. Kreps and K. Wallis, eds., 1997). 
shareholder wealth, seeks to establish optimal incentives for the executives. This view is captured in various formal models that view the board of directors as selecting an optimal compensation program for shareholders. As we will discuss, a great deal of empirical work has been done from this perspective.

The designer attempting to optimize an executive compensation program would be concerned with (1) attracting and retaining high quality executives, (2) providing executives with incentives to behave in the shareholders' interest both by exerting effort and by making decisions that will serve those interests, and (3) minimizing overall costs. We will consider briefly these elements of an optimal contract.

\section{Inducing the Executive to Take and Retain Position}

A successful CEO of a large public company undoubtedly possesses a rare combination of skills and instincts. The CEO must manage an organization with thousands of employees, provide the strategic direction for the firm, and decide when or whether the company should absorb other firms or be absorbed. Individuals who possess the necessary attributes may be scarce, ${ }^{9}$ and competition among firms, particularly for rising stars, may be intense. Of course, compensation is not the only factor in attracting and retaining talent at the very top of the corporate pyramid, but it is an important one.

To induce an executive to take and retain a position, then, a firm must offer an overall package of benefits that meets or exceeds the executive's opportunity cost. An executive's appetite for risk is relevant in this regard. A firm that requires a risk-averse executive to accept risky elements of compensation will have to provide more total compensation on an expected value basis to offset the risk-bearing costs.

Under the optimal-contracting view, inducing the executive to take and retain a position only provides a lower bound on compensation. A firm should not attempt to pay less than the executive's reservation wage, but it may pay more in order to provide desirable incentives. If the firm does exceed the reservation wage in order to optimize incentives, providing those incentives through risky compensation devices should not present a problem to the executive.

9 See Charles P. Himmelberg and R.G. Hubbard, Incentive Pay and the Market for CEO's: An Analysis of Pay-for-performance Sensitivity (working paper, 1999) (arguing that the sensitivity of CEO compensation to market returns (as opposed to company stock returns) may be explained by the inelasticity in the supply of CEO's who are able to run large companies). 


\section{Provision of Incentives}

There are two dimensions to the executive incentive problem. A firm must provide incentives that induce the executive to expend effort as well as incentives that motivate the executive to take shareholder-regarding decisions.

As in any agency relationship, there is the risk that the agent may expend too little effort on the principal's behalf. That is, executives may have an incentive to work less than is optimal for shareholders as a group. This distortion arises because executives enjoy all of the benefits of their leisure time (or other non-work activities) but capture only a fraction of the value their work generates for the firm.

The second agency problem in most public companies rests in the possibility that executives will make decisions that maximize their own utility but that fail to maximize shareholder value. ${ }^{10}$ Such decisions might include the erection of lavish skyscraping office buildings to house corporate headquarters staff or other excessive perquisite consumption; the selection of low risk business strategies; attempts to block value-adding takeover attempts; or the failure to reorganize and reduce the scope of operations when that is called for. The variety of critical decisions that may be faced by a CEO is extremely large, ${ }^{11}$ and the compensation device that properly aligns incentives in one case may be less effective in another. Moreover, the nature of the truly key decisions in the coming years often will be unforeseeable, thus complicating further the design of the optimal compensation plan.

\section{Costs}

The reservation wage places a lower bound on executive compensation, but a firm may wish to pay executives much more than the reservation wage to incentivize behavior that adds shareholder value. Under the optimal contracting view, shareholders should continue to give value to executives until the incremental cost of doing so outweighs the value of the incremental productivity achieved. Optimizing incentives probably will not require transferring a substantial fraction of firm value to the executives, however. As we will discuss below, creating desirable incentives is less a matter of the fraction of value transferred to the executives than the manner in which value is transferred. ${ }^{12} \mathrm{~A}$ compensation plan designer attempting to

10 See Murphy, supra note 3.

11 See id.

12 In addition to the direct cost of various compensation devices, a firm must consider a number of intangible factors in optimizing executive compensation, such as effects on employee morale and productivity and any social or political constraints. 
maximize shareholder value would take all of the incentive effects into account and would then optimize the mix based upon a forecast of the business environment over the plan period..$^{13}$

Although the specifics of the optimal executive compensation program will vary according to the circumstances, ${ }^{14}$ we can make certain general predictions about these contracts. First, variable pay schemes, such as bonus and stock options programs, will be adopted for performance sensitivity and will thereby shape the individual executive's incentives. ${ }^{15}$ Second, compensation devices will be selected and combined in a manner that attempts to balance incentive generation with the individual executive's appetite for risk. ${ }^{16}$ Third, optimal executive pay might well exceed the reservation wage in order to provide the incentives discussed above.

\section{B. Critique of the Optimal Contracting View}

There are three mechanisms through which executive compensation programs that optimize incentives and maximize shareholder value might be produced: (i) the board, acting at arm's length, selects the compensation structure that maximizes shareholder value; (ii) although the board acts under the influence of management, executives are constrained by market forces to select the structure that best serves shareholder interests; or (iii) shareholders can use the judicial system to challenge pay arrangements that are not in shareholders' interests. This Section shows that not one of these mechanisms holds.

${ }^{13}$ It is important to bear in mind, however, that an optimal principal-agent contract will not perfectly align managers' interests with those of shareholders. Some deviations cannot be eliminated cost-effectively.

${ }^{14}$ In actuality we observe little variety in executive compensation practice. Most companies utilize very similar salary, annual bonus, and stock option plans. This uniformity leads one to question whether compensation practice is consistent with shareholder value maximization. See infra Part IV.B. (explaining why the uniform use of at-the-money options is likely to be inconsistent with optimal contracting).

15 Given information asymmetry, it has been suggested that the optimal compensation plan must include current and future stock price performance. See John Bizjak et al, Stock-Based Incentive Compensation and Investment Behavior, $16 \mathrm{~J}$. ACCT. ECON. 349 (1993).

16 See Jonathan Eaton and Harvey S. Rosen, Agency Delayed Compensation and the Structure of Executive Remuneration, 39 J. FIN. 1489 (1984). See also Eugene F. Fama, Agency Problems and the Theory of the Firm, 88 J. POL. ECON. 288 (1980). 


\section{Limitations on Arm's Length Model of Boards}

The optimal-contracting literature assumes explicitly or implicitly that the directors take an adversarial or at least independent position in setting executive compensation. It is acknowledged that management plays a role in supplying data and proposals, but the board is viewed as representing shareholder interests specifically in this process and bargaining with management in an arm's length fashion. While the limitations on this model have been recognized by some students of corporate governance, ${ }^{17}$ their full force has not been generally appreciated in the academic literature on executive compensation. To explore these limitations it will be helpful to begin by examining the compensation process in greater detail.

In a large public corporation the board of directors is responsible for determining the compensation of the CEO and senior executives. Typically the board will adopt a multi-year compensation program that provides bounds on stock-based awards to the senior executives and lower level employees, and this plan will be ratified by the shareholders. ${ }^{18}$ Operating within the plan, however, the board has the authority to fix the compensation of senior executives on a periodic basis. ${ }^{19}$ Today the directors of essentially all the large, public companies in the U.S. have established compensation committees to which this function is delegated. ${ }^{20} \mathrm{~A}$ compensation committee typically is comprised of three or four directors, ${ }^{21}$ and in most firms the independent directors make up a majority of the committee. ${ }^{22}$

17 See, e.g., Victor Brudney, The Independent Director-Heavenly City or Potemkin Village, 95 HARV. L. REV. 597 (1982).

18 Ratification is virtually certain. Incumbent managers face a meaningful chance of losing a vote only if there is an active proxy contest. See Lucian A. Bebchuk and Marcel Kahan, A Framework for Analyzing Legal Policy Towards Proxy Contests, 78 CAL. L. REV. 1071 (1990). The question of ratifying stock-based awards is not sufficiently weighty to induce a challenger to wage a campaign.

19 One researcher finds that shareholder-approved plans in companies that are larger, more diversified, and more research-intensive tend to provide directors greater flexibility. See Stacey R. Kole, The Complexity of Compensation Contracts, 43 J. FIN. ECON. 79 (1997).

20 See Kenneth A. Bertsch et AL., BoArd Practices (1998), The Structure AND COMPENSATION OF BOARDS OF DIRECTORS AT S\&P SUPER 1500 COMPANIES (1998).

21 See id. (average committee size ranged from 3.3 directors among S\&P Small Cap 600 firms to 4.2 directors among S\&P 500 firms).

22 Bertsch, Leahey, and Haun report that in 1998 the average percentage of independent directors on compensation committees ranged from $83.5 \%$ among S\&P Small Cap 600 firms to $91.9 \%$ among S\&P 500 firms. See id. Directors are defined in their study as independent if they are not employed by the firm or "affiliated." A 
Three primary factors have led to the increasing use of compensation committees and the nominal independence of the directors who serve on them. First, investor advocacy organizations have long pushed for these improvements in corporate governance structure. ${ }^{23}$ Second, the tax code now provides corporations with a strong incentive to establish such committees. Since 1994, CEO and top officer pay in excess of $\$ 1,000,000$ annually per executive has not been deductible by a publicly held corporation unless the excess compensation is based upon the achievement of performance goals that have been established by a compensation committee comprised solely of independent outside directors. ${ }^{24}$ Third, the use of an independent compensation committee may provide some additional protection from judicial review or result in more deferential review of compensation programs. ${ }^{25}$

Despite the nominal independence of the majority of directors who serve on compensation committees, there are several reasons to be skeptical that the process of setting executive compensation approximates the arm's length ideal. The key problem is the pervasive influence of management, and particularly the CEO, on all facets of the process. ${ }^{26}$

director is considered "affiliated" is she is a former employee, a relative, a service provider, a supplier, a customer, or an interlocking director. See id. Yermack views the independence of these outside directors more skeptically, reporting earlier data indicating that "scores" of compensation committee members "benefited from personal consulting contracts or from the diversion of company business to their principal employers." See David Yermack, Good Timing: CEO Stock Option Awards and Company News Announcements, 52 J. FIN. 449 (1997). See also Nikos Vafeas, The Determinants of Compensation Committee Membership, 8 CORPORATE GOVERNANCE 356 (2000) (finding that compensation committee members (a) are rarely insiderdirectors, (b) hold no more equity than other board members, (c) tend to sit on more boards; and (d) tend to be older and have a longer tenure on the board).

${ }_{23}$ Current TIAA/CREF policy, for example, states that compensation committees should be independent, knowledgeable, and willing to use an outside compensation consultant in negotiating CEO compensation. See Fund Toughens on Executive Pay, INVESTOR RELATIONS BUS., Apr. 3, 2000.

${ }^{24}$ See IRC $\$ 162 \mathrm{~m}$. The employees whose compensation is covered by this rule include the CEO, or individual acting in that capacity, and individuals whose compensation must be reported under the Securities Exchange Act of 1934 as the top four most highly compensated officers other than the CEO. Non-employee directors who serve as consultants or who otherwise receive direct or indirect remuneration from the firm in a capacity other than as a director do not qualify as outside directors for the purposes of $\& 162 \mathrm{~m}$. See Treas. Reg. § 1.162-27(e)(3).

${ }^{25}$ See Robert CHARLES Clark, CORPORATE LAW (1986).

${ }^{26}$ Even the timing of stock option awards may be influenced to favor senior management. Yermack finds that that the timing of CEO option awards tends to immediately precede favorable movements in company stock prices. See David Yermack, Good Timing: CEO Stock Option Awards and Company News Announcements, 


\section{(a) Management Control over Director Appointment}

Management's domination of the compensation process begins with the selection of the corporation's directors who form the pool of candidates from which the compensation committee is selected.

Traditionally, the directors of a corporation serve at the pleasure of the CEO, and it is generally understood that the CEO dominates the director nomination process. ${ }^{27}$ While most boards employ a nominating committee, the CEO often formally serves on the committee. ${ }^{28}$ A 1998 survey found that only $27 \%$ of S\&P 1500 firms had fully independent nominating committees. ${ }^{29}$ When there is no nominating committee or the CEO is involved on the

52 J. FIN. 449 (1997). Managers can also release bad news prior to the grant date of options in order to reduce the strike price of the options (which is almost always set to the market price on the grant date). See Keith W. Chauvin and Cathy Shenoy, Stock Price Decreases Prior to Executive Stock Option Grants, 7 JOURNAL OF CORPORATE FINANCE: CONTRACTING, GOVERNANCE, AND ORGANIZATION 53 (2001).

${ }_{27}$ See Brian G. M. Main et al., The CEO, the Board of Directors, and Executive Compensation: Economic and Psychological Perspectives, 11 InDUS. \& CORP. CHANGE 293 (1995); Victor Brudney, The Independent Director-Heavenly City or Potemkin Village, 95 HARV. L. REV. 597, 597-659 (1982); Benjamin E. Hermalin and Michael S. Weisbach, Endogenously Chosen Boards of Directors and Their Monitoring of the CEO, 88 AMER. ECON. REV. 96 (1998) (suggesting that CEO's select directors but that their discretion to do so is circumscribed by explicit or implicit negotiations with the existing directors). For a review of the economic literature on boards of directors, see Benjamin E. Hermalin and Michael S. Weisbach, Boards of Directors as an Endogenously Determined Institution: A Survey of the Economic Literature (working paper, 2001).

${ }^{28}$ See Anil Shivdasani and David Yermack, CEO Involvement in the Selection of New Board Members: An Empirical Analysis, 54 JOURNAL OF FINANCE 1829 (1999) (reporting that $78 \%$ of 341 publicly traded Fortune 500 firms in 1994 had a nominating committee, and that in $33 \%$ of those firms the CEO was a member of the nominating committee). When a CEO serves on the nominating committee or when there is no nominating committee, firms appoint fewer independent outside directors and more outside directors with a conflict of interest. See id., at 1830. There are, of course, other factors that affect Board composition. See, e.g., Benjamin E. Hermalin and Michael S. Weisbach, The Determinants of Board Composition, 19 RAND J. ECON. 589 (1988) (finding that firms tend to add insider directors when CEO's near retirement and shed inside directors after a new $\mathrm{CEO}$ is appointed).

${ }^{29}$ See KenNeth A. Bertsch et AL., BoARd Practices (1998), The Structure AND COMPENSATION OF BOARDS OF DIRECTORS AT S\&P SUPER 1500 COMPANIES (1998). In the study, directors are classified as employees, affiliated, or independent. A director is deemed affiliated if, as disclosed in the proxy statement, he or she is a former employee, a relative of an executive, a representative of a charity that receives contributions from the firm, or a designated interlocking director. See id. at 9-10. 
committee, the stock price reaction to independent director appointments is significantly lower, and the independent directors appointed are more likely to serve on a large number of boards and to be stretched thin. ${ }^{30}$ A CEO's influence on the nomination process generally is thought to be considerable, however, even when he does not sit on the committee. ${ }^{31}$

\section{(b) Board Dynamics}

Most directors believe that their primary responsibility is to monitor the CEO's performance, and, if necessary, to fire him and hire a suitable replacement. ${ }^{32}$ Outside of this unfortunate circumstance, however, the directors are expected to support their CEO. Those who cannot do so in good faith are expected to step down. ${ }^{33}$ Overall, board meetings and processes are characterized by an emphasis on courtesy, politeness and deference to the CEO. ${ }^{34}$

(i) The "Support or Fire" Model. The role of the board of directors, as it is normally conceived, is to focus on the big picture and ensure that the personnel and strategies are in place that will lead to the company's success. Although setting executive compensation clearly is a board responsibility, it is plain that questioning the level or form of executive compensation proposed by an effective CEO (or his compensation consultant) runs counter to the predominant "support or fire" model of the board of directors. ${ }^{35}$

30 See Anil Shivdasani and David Yermack, CEO Involvement in the Selection of New Board Members: An Empirical Analysis, 54 JOURNAL OF FINANCE 1829 (1999).

31 See Brian G. M. Main et al., The CEO, the Board of Directors, and Executive Compensation: Economic and Psychological Perspectives, 11 INDUS. \& CORP. CHANGE 293 (1995).

32 See Graef S. Crystal, In SeArCh Of Excess (1991); Jay W. Lorsch and Elizabeth M. MacIver, PAWNS OR POTENTATES? THE REALITY OF AMERICA'S CORPORATE BOARDS (1989).

33 See Brian G. M. Main et al., The CEO, the Board of Directors, and Executive Compensation: Economic and Psychological Perspectives, 11 INDUS. \& CORP. CHANGE 293 (1995).

34 See Michael C. Jensen, The Modern Industrial Revolution, Exit and the Failure of Internal Control Systems, 48 J. FIN. 831, 863 (1993).

35 Generally, the board is thought to be relatively ineffective in removing poorly performing CEO's, and the empirical evidence supports this view. See Stuart C. Gilson, Management Turnover and Financial Distress, 25 J. FIN. ECON. 241 (1989) (finding that only 28 of 176 CEO replacements were explicitly caused by the board, but noting that the majority of turnovers were unexplained). See also David J. Denis and Diane K. Denis, Performance Changes Following Top Management Dismissals, 50 J. FIN. 1029 (1995) (finding that forced CEO resignations are rare and that twothirds of those that occur are caused by factors other than board monitoring, such as blockholder pressure or a takeover attempt). Cf. Mark R. Huson, Robert Parrino and Laura Starks, The Effectiveness of Internal Monitoring Mechanisms: Evidence from 
Independent directors are thus likely to be reluctant to confront a CEO regarding the amount of his pay and perquisites. ${ }^{36}$ This reluctance might stem from a perception that their effort and scrutiny are better focused on policy matters, ${ }^{37}$ or the perception that they are not as knowledgeable about compensation issues as the management or compensation consultant.

(ii) Social Dynamics. Although the use of a compensation committee comprised solely of independent directors mitigates to some extent the influence of the CEO on executive compensation, it is no panacea. The social dynamics of the board or compensation committee, the members of which have been selected in large part by the CEO or with his input, ${ }^{38}$ play an important role in deterring objection to executive compensation programs. It is well known that individuals working within a group feel pressure to placate group members, often at the expense of interests that are not directly represented at the table. ${ }^{39}$ The relationship between the CEO and the board is also likely to produce additional dynamics specific to that particular setting. Main, O'Reilly, and Wade conclude that the directors who serve on the committee are influenced by notions of reciprocity, authority, and

CEO Turnover Between 1971 and 1994, 15 (working paper, 1997) (finding that 23.4\% of turnovers in large public US firms during the period 1989-1994 were involuntary). However, it has been shown that firms with outsider-dominated boards are significantly more likely to remove the CEO on the basis of poor stock performance than are firms with insider-dominated boards. See Michael S. Weisbach, Outside Directors and CEO Turnover, 20 J. FIN. ECON. 431 (1988). See also Warren Boeker, Power and Managerial Dismissal: Scapegoating at the Top, 37 ADMIN. SCI. Q. 400 (1992) (finding that the likelihood that poorly performing CEO's of semiconductor firms will be replaced decreases as the percentage of inside directors increases and that excessive executive compensation may contribute to poor performance, although the link is tenuous). The increased likelihood of the removal of a poorly performing CEO also may account for the finding of a positive share price reaction to the appointment of an outside director. See Stuart Rosenstein and Jeffrey G. Wyatt, Outside Directors, Board Independence, and Shareholder Wealth, 26 J. FIN. ECON. 175 (1990).

${ }^{36}$ However, there is some evidence that the pay-performance sensitivity of the CEO's compensation increases with the percentage of independent outside directors. See Chandra S. Mishra and James F. Nielsen, Board Independence and Compensation Policies in Large Bank Holding Companies, __ FINANCIAL MANAGEMENT 51 (Autumn 2000) (finding evidence that the presence of outside directors in large bank holding companies increases pay-performance sensitivity).

37 See Victor Brudney, The Independent Director-Heavenly City or Potemkin Village, 95 HARV. L. REV. 597 (1982).

38 See Brian G. M. Main et al., The CEO, the Board of Directors, and Executive Compensation: Economic and Psychological Perspectives, 11 INDUS. \& CORP. CHANGE 293 (1995).

39 See Melvin A. Eisenberg, The Compensation of Chief Executive Officers and Directors of Publicly Held Corporations, ALI-ABA (1999). 
similarity in their deliberations concerning executive compensation. ${ }^{40}$ Specifically, they find that compensation committee chairmen who are appointed after the CEO takes office tend to reciprocate by awarding higher CEO compensation. ${ }^{41}$ They also find a significant association between the compensation level of an outsider who serves on the compensation committee and CEO pay. ${ }^{42}$

(iii) Self-Serving Cognitive Dissonance. It has also been suggested that a CEO benefits when an active and well-paid CEO of another firm sits on the compensation committee. ${ }^{43}$ This phenomenon could be viewed as pure selfinterest: by approving high compensation for the evaluated CEO, the outside $\mathrm{CEO}$ increases the compensation baseline. Alternatively, it may be seen as a form of cognitive dissonance wherein the outside CEO internally justifies his high pay and that of the subject CEO by viewing the compensation data in its most favorable light. In 1998 25\% of compensation committee members were CEO's, and some highly compensated CEO's served on several compensation committees. ${ }^{4}$

40 See Brian G. M. Main et al., The CEO, the Board of Directors, and Executive Compensation: Economic and Psychological Perspectives, 11 INDUS. \& CORP. CHANGE 293 (1995). This work is influenced by more general research on small group dynamics. See J. S. Coleman, Constructed Organizations: First Principles, 7 J. L. ECON. \& ORG. 7 (1991); R. B. Cialdini, Influence: The NeW PsyChOlOGy OF MOdeRN PERSUASION (1993).

41 See Brian G. M. Main et al., The CEO, the Board of Directors, and Executive Compensation: Economic and Psychological Perspectives, 11 INDUS. \& CORP. CHANGE 293 (1995).

42 See Brian G. M. Main et al., The CEO, the Board of Directors, and Executive Compensation: Economic and Psychological Perspectives, 11 INDUS. \& CORP. CHANGE 293 (1995); Charles A. O'Reilly et al., Overpaid CEO's and Underpaid Managers: Equity and Executive Compensation (working paper, 1998) (finding evidence that CEO pay is related to the pay levels of the members of the compensation committee). Cf. Maura A. Belliveau et al., Social Capital at the Top: The Effects of Social Similarity and Status on CEO Compensation, 39 ACAD. MGMT. J. 1568 (1996) (finding no support for proposition that social similarity between $\mathrm{CEO}$ and chair of compensation committee increases CEO compensation, but finding that CEO's with relatively high social status versus peers and with high social status compared with chairmen of committees do receive higher compensation).

43 See CRYSTAL, supra note 6. However, there is apparently no effect in CEO pay when other types of outside executives are on the board. See Ronald C. Anderson and John M. Bizjak, An Empirical Examination of the Role of the CEO and the Compensation Committee in Structuring Executive Pay (working paper, 2000) (finding no evidence that CEO's receive greater pay when executives or retired executives of other firms sit on the compensation committee).

44 See Kenneth A. Bertsch et AL., BoArd Practices (1998), The Structure AND COMPENSATION OF BOARDS OF DIRECTORS AT S\&P SUPER 1500 COMPANIES 20 (1998). 


\section{(c) Insufficient Incentives}

CEO control over the board nomination process and board dynamics militate against effective executive compensation oversight by independent directors. Unfortunately, outside directors generally lack the economic incentive to overcome these forces. The benefits of attempting to curb excessive executive compensation are low, while the potential costs are high.

(i) Economic Benefits. Although stock-based compensation for outside directors is on the rise $-81 \%$ of S\&P 500 firms awarded directors stock or options in $1997^{45}$ - the direct benefit to independent directors of reducing the CEO's compensation remains insignificant in almost all cases. ${ }^{46}$ Even if excessive CEO pay results in somewhat higher compensation throughout the managerial ranks, the impact is unlikely to be felt by a director who holds only several thousand options. ${ }^{47}$ Further, as we will discuss below, the incremental compensation cost incurred by a company with less than vigilant directors is unlikely to pose a sufficient prize to spark a hostile takeover and threaten the independent directors' position on the board.

(ii) Economic Costs. While the benefit to independent directors of reducing the CEO's salary is minimal, the cost of trying to do so could be considerable. As explained previously, CEO's have significant influence on the appointment and re-appointment of outside directors. This influence makes director compensation activism costly in two ways. First, and most importantly, the CEO has an incentive to throw an uncooperative director off the board (or not reappoint the director when his term expires). In many cases the CEO will have the power, through his relationships with other board members, to do so. If the director is expelled or his directorship is not

45 See id. at 37.

46 See George P. Baker et al., Compensation and Incentives: Practice vs. Theory, 43 J. FIN. 593 (1988) (arguing that directors fail to create proper executive pay incentives because the directors bear a large share of nonpecuniary costs and receive little monetary benefit from improved compensation practices). Options aside, directors' fees have increased only modestly over the past two decades. See Melvin A. Eisenberg, The Compensation of Chief Executive Officers and Directors of Publicly Held Corporations, ALI-ABA (1999) (reporting that the average Fortune 500 director's fee increased from $\$ 30,000$ in 1980 to $\$ 50,000$ in 1994).

47 On average, directors of S\&P 500 firms who received annual options received approximately 3500 options in 1998. See KENNETH A. BERTSCH ET AL., BOARD PRACTICES (1998), THE STRUCTURE AND COMPENSATION OF BOARDS OF DIRECTORS AT S\&P SUPER 1500 COMPANIES 39 (1998). Independent directors with more substantial shareholdings might have an incentive to limit executive compensation. See Richard Cyert et al., Corporate Governance, Ownership Structure, and CEO Compensation (working paper, 1997) (finding that CEO pay is negatively related to the level of equity holdings of compensation committee members). 
renewed, the director will lose the salary and benefits he gets from the firm. ${ }^{48}$ The risk of losing one's directorship as a result of challenging the CEO's compensation must be orders of magnitude greater than the risk presented by the takeover market. 49

Second, there is likely to be a reputational cost of trying to reduce the CEO's compensation. In particular, other CEO's are unlikely to appoint or reappoint to their boards a director with a reputation for challenging executive compensation, thus depriving the director of the salary and perks associated with membership on other boards. Finally, reducing the CEO's compensation would also indirectly hurt the independent director if the director is a CEO whose pay is linked broadly to that of other CEO's. This is especially true if the firms appear in each other's comparative groups when pay surveys are compiled. ${ }^{50}$

(iii) The Market for Directors. Fama and Jensen have argued that independent directors have an incentive to develop reputations as experts in decision control, which they can do by safeguarding shareholder interests. 51 Their idea is as follows: Independent directors normally are CEO's or other decision managers in their primary jobs, and the value of their human capital depends on their decision management reputation. Effective independent directors signal to the managerial labor market that they are indeed experts in decision control. Thus, Fama and Jensen might argue that -- in addition to the direct financial benefit of reducing CEO compensation through its effect on the value of directors' options -- there might also be a reputational benefit to attempting to reduce CEO compensation.

48 It is reasonable to think that in many cases a CEO would be able to rally a majority of board members to his side to replace the problem director when his term expires. Any inside directors can be mobilized by the CEO because they are beholden to the CEO and their own salary may well depend, at least in part, on the CEO's. Outside directors may well go along with the CEO to protect their own positions, to curry favor with the $\mathrm{CEO}$, who has influence over board compensation, or simply to make board meetings less fractious and unpleasant.

49 A study of the determinants of CEO compensation in Australia finds that CEO compensation is decreasing as the amount of equity held by outside directors and increasing as the salary paid outside directors rises. See Robert Evans and John Evans, The Influence of Non-Executive Director Control and Rewards on CEO Remuneration: Australian Evidence (working paper, 2000). The first finding suggests that outside directors are more likely to curb CEO compensation when the benefits of reducing CEO compensation are higher. The second suggests that outside directors are less likely to curb CEO compensation when the costs (the possibility of losing their seats and the salary that comes with them) are higher.

50 See David Yermack, Good Timing: CEO Stock Option Awards and Company News Announcements, 52 J. FIN. 449 (1997).

51 See Eugene F. Fama and Michael C. Jensen, Separation of Ownership and Control, 26 J. L. \& ECON. 301 (1983). 
While this mechanism may work in certain cases, we are skeptical about its effect on many, if not most, directors. First, the signal provided by independent directorships is likely to be quite noisy, particularly when the board is large and responsibilities are diffuse. Second and relatedly, the managerial labor market is more likely to focus on the manager's performance in his primary role rather than in his independent directorships. More importantly, there are likely to be a considerable number of independent directors who are paid nontrivial amounts for serving on the board or who derive significant psychic benefits from sitting on the board of a publicly traded company. As explained, CEO's have considerable influence in the choice of independent directors, and CEO's seeking directors prefer nonconfrontational individuals. ${ }^{52}$ For these directors, the "market" for directors creates incentives not to challenge the CEO on the issue of his compensation but rather to accommodate the CEO's wishes.

Given the process of director selection and retention, board and committee processes and dynamics, and the lack of an effective incentive structure, it is unlikely that Fama and Jensen's "decision control expert" story will result in independent directors engaging in effective arm's length bargaining with the CEO over his compensation. Instead, reputation and social pressure are likely to play a role in limiting the degree to which the independent directors are willing to challenge management in this area.

\section{(d) Information Disparities}

We have just shown that directors, including independent directors, are likely to have neither the inclination nor the incentive to engage in arm's length bargaining with the CEO. We now wish to point out that even if directors have the inclination and incentive to negotiate for CEO compensation that maximizes shareholder value, they will usually lack the information to do so effectively.

Information is not dispersed uniformly within the corporate boardroom. Independent directors have limited time and resources available to devote to increasingly complex compensation issues. ${ }^{53}$ The CEO, by way

52 To be sure, one could argue that market forces will prevent CEO's from appointing directors who are too pliant and instead will force them to appoint directors who engage in arm's length bargaining with the CEO. This is a variant of the argument that even if CEO's have influence over the board, market forces will force the board to negotiate with the CEO at arm's length. We will address this argument shortly.

53 See Brian G. M. Main et al., The CEO, the Board of Directors, and Executive Compensation: Economic and Psychological Perspectives, 11 INDUS. \& CORP. CHANGE 293 (1995); Victor Brudney, The Independent Director-Heavenly City or Potemkin Village, 95 HARV. L. REV. 597, 597-659 (1982); Michael C. Jensen, The Modern 
of his personnel department, controls much of the information that reaches the committee. TIAA/CREF has recommended that compensation committees be "willing" to employ an independent compensation consultant, $^{54}$ but normally the firm (i.e., management) employs the consultant that provides the data to the committee. ${ }^{55}$ Even if the consultant's compensation data are perfectly accurate, there is a great deal of flexibility and discretion involved in choosing the companies that are used for comparison, determining the economic scenarios that will be presented to the committee, and generally deciding what data will be presented and how. ${ }^{56}$ Because managers choose which compensation consultants to hire, the consultants have a clear incentive to make recommendations that curry favor with managers. To be sure, the consultant is somewhat constrained by reputational considerations - she cannot propose a pay package that is obviously excessive. But within the range of flexibility and discretion, the consultant has an incentive to provide information in a way that is most favorable to managers. Thus, the information presented and the way it is framed will be chosen with an eye toward maximizing managers' compensation.

\section{Limitations on the Power of Market Forces}

Although outside directors are unlikely to bargain with management over their compensation in a manner that approaches the arm's length ideal, we must consider whether the CEO and more junior executives will be induced by market forces not to push for anything other than optimal compensation contracts. There is an important school of thought in corporate law and finance scholarship that takes the view that markets for managerial labor, corporate control, capital, and products effectively align management and shareholder interests. ${ }^{57}$ As one of us has argued in earlier work, however, these market mechanisms cannot be relied upon to align

Industrial Revolution, Exit and the Failure of Internal Control Systems, 48 J. FIN. 831, 863 n. 35 (1993).

54 See Fund Toughens on Executive Pay, InVESTOR Relations Bus., Apr. 3, 2000.

55 See Graef S. CRYSTAL, IN SEARCH Of EXCESS (1991).

56 See id. As we discuss below, compensation consultants have an incentive to produce data that favors the insiders who select them. Consultants must protect their reputation for accuracy, of course, but they can safely operate within a range of discretion. Thus, the information provided and the way in which it is framed would tend to be skewed in favor of those who hire them - managers.

57 See Frank H. Easterbrook, Managers' Discretion and Investors' Welfare: Theories and Evidence, 9 DEL. J. CORP. L. 540 (1984); Eugene F. Fama, Agency Problems and the Theory of the Firm, 88 J. POL. ECON. 288 (1980); Daniel R. Fischel, The Race to the Bottom Revisited: Reflection on Recent Development in Delaware's Corporation Law, 76 NW. U. L. REV. 913 (1982). 
managers' and shareholders' interests with respect to significantly redistributive issues - decisions by which the managers can transfer to themselves value that is substantial relative to the resulting loss to shareholders. ${ }^{58}$ Executive compensation, which approaches a direct transfer from shareholders to management, would seem to be an especially clear case of a significantly redistributive issue for which market forces will provide insufficient discipline. We will briefly review the market forces that bear upon managerial behavior activity and discuss why they are unlikely to impose significant restraints on executive compensation.

\section{(a) Managerial Labor Markets}

Several labor market mechanisms tend to align the interests of executives with those of shareholders. Executives' compensation packages (as well as their equity holdings) provide the most direct incentives. The typical senior executive's compensation package is composed of base salary, annual bonus, stock options and/or restricted shares, and often other longterm incentive elements. ${ }^{59}$ Each of these components is sensitive to firm performance to some degree and contributes to incentive alignment, although performance-based adjustments to salary and bonus tend to be sluggish and relatively unimportant. ${ }^{60}$ Among the firm's executives, the CEO typically holds the greatest number of shares and options. Hence the CEO's wealth will fluctuate the most in absolute terms with firm value. ${ }^{61}$

58 See Lucian A. Bebchuk, Federalism and the Corporation: The Desirable Limits on State Competition in Corporate Law, 105 HARV. L. REV. 1435 (1992); Lucian A. Bebchuk, Limiting Contractual Freedom in Corporate Law: The Desirable Constraints on Charter Amendments, 102 HARV. L. REV. 1820 (1989); Lucian A. Bebchuk and Mark J. Roe, A Theory of Path Dependence in Corporate Ownership and Governance, 52 STANFORD L. REV. 775 (1999).

59 See Murphy, supra note 3.

60 Salary figures are largely determined through the use of compensation surveys and a process of benchmarking against industry peers. As a result, CEO base salaries historically have been highly correlated with firm size. See George P. Baker, et al., Compensation and Incentives: Practice vs. Theory, 43 J. FIN. 593 (1988). However, more recent evidence suggests that this correlation is diminishing and that CEO salary and bonus payments are becoming more sensitive to performance. See Murphy, supra note 3; Paul L. Joskow and Nancy L. Rose, CEO Pay and Firm Performance: Dynamics, Asymmetries, and Alternative Performance Measures, NBER (working paper, 1996). Nevertheless, Perry and Zenner report that in the mid-1990s only $2-4 \%$ of the sensitivity of CEO wealth to shareholder value is attributable to annual cash compensation and long-term incentive plans. The remaining sensitivity arises from share and option holdings. See Perry and Zenner, supra note 1.

61 See Rajesh K. Aggarwal and Andrew A. Samwick, Performance Incentives Within Firms: The Effect of Managerial Responsibility (working paper, 1999). 
Over the past two decades the sensitivity of the average CEO's wealth to firm performance has increased by an order of magnitude with the explosive growth of stock option plans, but, given the enormous size of large U.S. companies, the absolute sensitivity of CEO wealth to performance remains small. For a $\$ 1000$ change in firm value, the wealth of the average CEO of a large, public corporation currently changes only by about $\$ 10.62$

All else being equal, then, a CEO who wrote himself a check for an extra $\$ 1000$ would net about $\$ 990$ after taking into account the impact of the change in firm value on his shares and options. But all else is not equal. Although there appears to be a widening gap between the compensation of U.S. CEO's and junior executives, ${ }^{63}$ there is some evidence that when CEO's are overpaid (or underpaid), a diminishing echo effect is felt throughout the organization. ${ }^{64}$ Moreover, inequity between the compensation of the CEO and his subordinates has been shown to be associated with higher rates of managerial turnover. ${ }^{65}$ Hence, a CEO would have to take these factors into account prior to awarding himself a pay raise.

Nonetheless, the sensitivity of their wealth to firm value alone would dissuade few CEO's from increasing their compensation. It is difficult to gauge the significance of the compensation echo effect, but one indication may be provided by the distribution of options. In 1998, the CEO's of S\&P 1500 corporations received $14.2 \%$ of all options issued while the top five

62 Based on 1974-1986 data, Jensen and Murphy calculated median CEO wealth to shareholder value sensitivity of $\$ 3.25$ per $\$ 1000$, and this figure included an adjustment for risk of dismissal. See Michael Jensen and Kevin J. Murphy, Performance Pay and Top-Management Incentives, 98 J. POL. ECON. 225 (1990). More recently Perry and Zenner have shown that in 1997 the median S\&P 1500 CEO stood to gain or lose $\$ 11.50$ per $\$ 1000$ of shareholder gain or loss. See Perry and Zenner, supra note 1. Similarly, Hall and Liebman have estimated 1998 CEO wealth to shareholder value sensitivity of approximately $\$ 11$ per $\$ 1000$ based on a firm with market capitalization of $\$ 1$ billion. See Brian Hall and Jeffrey B. Liebman, The Taxation of Executive Compensation NBER Working Paper 7596 (2000). These latter figures exclude adjustment for risk of dismissal.

63 See John M. Abowd and Michael L. Bognanno, International Differences in Executive and Managerial Compensation, in DIFFERENCES AND CHANGES IN WAGE STRUCTURES 67 (R. Freeman and L. Katz, eds., 1995).

64 See Charles A. O'Reilly, et al., Overpaid CEO's and Underpaid Managers: Equity and Executive Compensation (working paper, 1998).

65 See id. Vertical pay inequity within an organization may also be associated with poorer product quality. See Douglas M. Cowherd and David I. Levine, Product Quality and Pay Equity Between Lower-Level Employees and Top Management: An Investigation of Distributive Justice Theory, 37 ADMIN. SCI. Q. 302 (1992). 
executives received $30 \% .{ }^{66}$ If the distributive pattern of overcompensation is at all similar, there remains an order of magnitude difference between the direct gain and cost to the CEO of increasing executive pay levels. ${ }^{67}$

Of course, compensation is just one element of the managerial labor market. Executives are also concerned with the possibilities of promotion or dismissal and with being tapped for higher-level positions by other firms. However, the possibility of promotion is of diminished significance for the $\mathrm{CEO}$ - the person driving the executive compensation process. For the CEO, internal promotion is, of course, impossible. To be sure, external promotion is always a possibility. She could become the CEO of a larger or more prestigious firm. But most CEO positions are filled internally. ${ }^{68}$ Thus for the CEO there may well be few other jobs that are both available and more desirable than her current one. Finally, the ability to get those jobs will depend on the CEO's overall performance at her current firm, not on the amount of rent extracted. 69

The risk of being fired depends more upon overall performance than on the CEO's level of compensation, and this risk is small in any event. ${ }^{70}$ In

66 See Kathy B. Ruxton, EXeCutive PAy, 1997: CHIEF EXECuTIVE OfFICER COMPENSATION AT S\&P SUPER 1,500 COMPANIES AS REPORTED IN 1997, Investor Responsibility Research Center (1998).

67 Using these figures as an example, a CEO direct pay boost of $\$ 142$ would result in a total firm-wide compensation increase of $\$ 1000$, which would result in about a $\$ 10$ cost to the CEO on his stock and options. This calculation assumes, however, that overcompensation throughout the ranks has no impact on productivity, which is unlikely. More realistically, overcompensation results in increased productivity, but at an insufficient level to offset the higher payments. Thus shareholder value falls, but not to the full extent of the overcompensation, and hence the cost to the CEO as a share/option holder would be even less.

68 See C. Edward Fee and Charles J. Hadlock, Raids, Rewards, and Reputations in the Market for CEO Talent 10 (working paper, 2001) (reporting that in a sample of 1200 CEO hires during the period 1990-98, 73.5\% were internal hires).

69 The probability of being hired as CEO for another firm (which is low), is positively related to the stock price performance at one's current firm. See C. Edward Fee and Charles J. Hadlock, Raids, Rewards, and Reputations in the Market for CEO Talent (working paper, 2001). However, the initial hiring grant for the new job is highly correlated with the value of unvested options and restricted stock the CEO leaves behind. See id, at 39. Thus, on balance, CEO's contemplating moving to another CEO position would appear to have an incentive to inflate their compensation as much as possible.

70 Murphy finds that departure rates for the CEO's of S\&P 500 bottomquartile performers averaged 15\% from 1970 through 1995, while departure rates for the remaining S\&P 500 CEO's averaged 11\%. See Murphy, supra note 3. For other work on executive turnover and firm performance, see Anne T. Coughlan and Ronald M. Schmidt, Executive Compensation, Management Turnover, and Firm Performance: An Empirical Investigation, 7 J. ACCT. ECON. 43 (1985); Jerold B. Warner 
their seminal 1990 study, Jensen and Murphy calculated that the median CEO suffers a dismissal-related wealth reduction of $\$ 0.30$ per $\$ 1000$ reduction in shareholder value, ${ }^{71}$ and no clear time trend in the firm performance/dismissal relationship has been established. ${ }^{72}$ It seems highly unlikely that the small added threat of dismissal would dissuade a CEO from granting himself and the other executives increased compensation. ${ }^{73}$

\section{(b) Market for Corporate Control}

The market for corporate control is also viewed as a strong force aligning the interests of management and shareholders. ${ }^{74}$ A company that experiences a relative drop in share price should become more vulnerable to a takeover attempt, and the executives of a firm that is taken over face a high risk of loss of position, pay, and perquisites. Despite widespread adoption of poison pills and other takeover defenses, the corporate control market has remained active. ${ }^{75}$

The takeover threat, however, is unlikely to discourage management from seeking an increase in executive compensation. Consider an executive of a $\$ 10$ billion company who contemplates increasing executive compensation by $\$ 100$ million over the next several years. Obviously, the

et al, Stock Prices and Top Management Changes, 20 J. FIN. ECON. 461 (1988); Michael S. Weisbach, Outside Directors and CEO Turnover, 20 J. FIN. ECON. 431 (1988); Wayne H. Mikkelson and M. Megan Partch, The Decline of Takeovers and Disciplinary Turnover, 44 J. FIN. ECON. 205 (1997); Warren Boeker, Power and Managerial Dismissal: Scapegoating at the Top, 37 ADMIN. SCI. Q. 400 (1992); Stuart C. Gilson and Michael R. Vetsuypens, CEO Compensation in Financially Distressed Firms: An Empirical Analysis, 48 J. FiN. 425 (1993). For analysis of executive turnover abroad see Steven Kaplan, Top Executive Rewards and Firm Performance: A Comparison of Japan and the United States, 102 J. POL. ECON. 510 (1994); Steven Kaplan, Top Executives, Turnover, and Firm Performance in Germany, 10 J. L. ECON. \& ORG. 142 (1994); Jun-Koo Kang and Anil Shivdasani, Firm Performance, Corporate Governance, and Top Executive Turnover in Japan, 38 J. FIN. ECON. 29 (1995).

71 See Michael Jensen and Kevin J. Murphy, Performance Pay and TopManagement Incentives, 98 J. POL. ECON. 225 (1990).

72 See Murphy, supra note 3.

73 The junior executives are concerned about promotion within or outside the firm, but they have much less say in the compensation setting process and are much less likely than the CEO to be tainted by any perception of excessive compensation.

74 See Frank H. Easterbrook, Managers' Discretion and Investors' Welfare: Theories and Evidence, 9 DEL. J. CORP. L. 540, 564 (1984); Henry G. Manne, Mergers and the Market for Corporate Control, 73 J. POL. ECON. 110 (1965).

75 See John C. Coates IV, Takeover Defenses in the Shadow of the Pill: A Critique of the Scientific Evidence, 79 TEXAS LAW REVIEW 271 (2000) (reporting that nearly 70 hostile bids were made in 1995, a figure that exceeds the pace of the 1980s, and that negotiated deals reached an all time high in 1998). 
direct benefit to the executive is very large. The cost to the executive is the enhanced risk of takeover and ouster, but the increase in takeover risk resulting from a $1 \%$ reduction in firm value is bound to be quite limited. ${ }^{76}$

Commentators who believe most fervently in the disciplining force of takeovers admit that control transactions are very costly and useful only as a response to substantial performance shortfalls. ${ }^{77}$ Excessive compensation may be a symptom of more pervasive management shortcomings, but the limited evidence available does not support the proposition that overcompensation increases takeover risk. A study of Forbes 800 firms in the 1980s determined that takeover bids were more common in industries in which CEO's were overpaid, but found no significant difference between the compensation of the CEO's of firms that were and were not targeted for takeover within these industries. ${ }^{78}$ If there is an added risk of takeover, it appears to be small, and it is not likely to deter executives from pushing for the highest possible compensation.

\section{(c) Market for Additional Capital}

Another source of market discipline arises from the possibility that the firm will need to return to the market for additional equity capital in order to support expansion - a prospect that would cause a value-maximizing management team to maintain restraint and develop a reputation as conservative self-compensators. The failure of management to do so, however, is unlikely to impede their access to equity capital or limit their expansionary aims. Instead, a pattern of excessive self-compensation will raise slightly a firm's cost of capital. Future investors will pay something less for the firm's shares in a secondary offering based on their recognition of management's excessive compensation, so more shares would have to be issued to raise a given amount of capital. Of course this effect leads to a reduction in value that is borne by all existing shareholders, including the executive team, but again the impact of this reduction in share value on managerial wealth and the likelihood of ouster via takeover will be considerably less than the direct benefit of taking additional compensation.

76 This simplified example ignores the compensation echo effect we mentioned in the prior subsection, but that effect does not disturb the conclusion that the direct benefit of increased compensation overwhelms the expected cost.

77 Easterbrook suggests that a potential increase in value of about $20 \%$ is needed to trigger a control transaction. See Frank H. Easterbrook, Managers' Discretion and Investors' Welfare: Theories and Evidence, 9 DEL. J. CORP. L. 540, 567 (1984).

78 See Anup Agrawal and Ralph A. Walking, Executive Careers and Compensation Surrounding Takeover Bids, 49 J. FIN. 985, 986 (1994). 


\section{(d) Product Markets}

A final possible external constraint on management behavior is that created by competition in product markets. In a competitive market, it is argued, inefficient behavior produces competitive disadvantage, shrinking profits, and business contraction or failure. ${ }^{79}$ Although this effect may discourage management from acting in ways that decrease productivity, the redistribution of firm profits from shareholders to executives has no significant effect on the operational efficiency of the company, ${ }^{80}$ and hence this factor will not inhibit excessive compensation.

\section{(e) Overall Force}

Even in aggregate the foregoing market forces are unlikely to impose significant constraints on executive self-compensation. The analysis and limited evidence indicate that the incentives for restraint provided by the executives' stock and option holdings vastly outweigh any other incentives. These direct incentives are far from sufficient to induce managerial selfdiscipline with regard to such a significantly redistributive matter as executive compensation.

This conclusion is supported by evidence that suggests that market constraints generally are not binding on executive compensation. Core, Holthausen, and Larcker find that executive compensation is greater when the arm's length bargaining process is undermined. ${ }^{81} \mathrm{CEO}$ compensation is greater, for example, when the CEO also serves as board chairman; when the board is large or consists of a greater fraction of outside directors; and when more outside directors are appointed by the current CEO or are burdened with some conflict of interest, are old, or serve on five or more boards. ${ }^{82}$ This suggests that it is not markets but rather the power of the CEO vis-à-vis the board that can constrain executive compensation.

79 See Frank H. Easterbrook, Managers' Discretion and Investors' Welfare: Theories and Evidence, 9 DEL. J. CORP. L. 540, 557 (1984).

80 As noted earlier, there is evidence that inequity between CEO compensation and compensation at lower levels is associated with increased managerial turnover. Higher turnover could have some impact on operational efficiency. See Charles A. O'Reilly et al., Overpaid CEO's and Underpaid Managers: Equity and Executive Compensation (working paper, 1998).

81 See John E. Core et al., Corporate Governance, Chief Executive Officer Compensation, and Firm Performance, 51 J. FIN. ECON. 371 (1999).

82 See id. 


\section{The Practical Absence of Judicial Review}

Although neither market forces nor bargaining between the board and the CEO is likely to ensure optimal contracting, in theory such contracting could arise if shareholders could use the courts to throw out compensation packages that do not maximize shareholders' value. In fact, corporate law permits shareholders to challenge legally a particular compensation package under a variety of doctrines. However, the obstacles to the success of such a lawsuit all but ensure that courts do not review the substantive merits of management compensation arrangements. Thus, as a practical matter, judicial review fails to impose any constraint on executive pay. ${ }^{83}$

To overturn a board's decision to grant a particular pay package, shareholders would be required to show that the board had violated its duty of care, committed "waste," or breached the duty of loyalty. As we will explain, it is all but impossible to prove any of these violations. Before describing each of these legal standards, however, it will be useful to examine the procedural barrier that make it extremely unlikely that shareholders will even get to the stage where such claims are heard.

Excessive compensation does not hurt shareholders directly but rather indirectly through their equity interests in the firm. Thus, shareholders cannot sue the board directly for claims relating to executive pay. To challenge board decisions involving executive compensation, shareholders generally must file a derivative suit -- a suit brought on behalf of the corporation -- that alleges that the corporation has been hurt by the board's decision (in this case, to grant excessive pay to management).

Because shareholders generally do not make decisions on behalf of the corporation board - these decisions are made by the firm's officers and directors - the courts severely restrict shareholders' ability to proceed with a derivative suit. The most important procedural restriction is the "demand requirement." Under this requirement, shareholders must "make demand" on the board to investigate the problem and take whatever steps are necessary to correct it. If there is a failure to make demand, the board can

83 See Linda J. Barris, The Overcompensation Problem: A Collective Approach to Controlling Executive Pay, 68 INDIANA LAW JOURNAL 59, 80 (1992) (reporting that in almost all cases since 1900 involving publicly traded firms courts have refused to overturn compensation decisions). There are other corporate law mechanisms that could in theory be used to give shareholders some influence over executive compensation decisions. For example, shareholders often vote on firm-wide option plans and individual shareholders sometimes put forward shareholder resolutions challenging the board's compensation decision making. However, it is widely believed that neither of these mechanisms provides a meaningful constraint on the pay arrangements for executives. We will examine these two mechanisms in a later version of this paper. 
usually have the case dismissed. ${ }^{84}$ An exception is made, however, when shareholders can show that such a demand would be "futile."

If the shareholders make demand on the board to pursue the litigation (which, recall is against one or more members of the board itself), the board will take control over the suit. ${ }^{85}$ The board will then almost always dismiss the lawsuit. ${ }^{86}$ If the board appears to have acted independently, and to have conducted a reasonable investigation of the allegations, the court will grant the motion to dismiss, ending the legal challenge to the compensation. Because demand leads in effect to the termination of the lawsuit, shareholders must claim that demand on the board is futile. Establishing demand futility requires the plaintiff to offer "particularized facts" that either (1) create a reasonable doubt as to the independence of the majority of the board of directors or (2) show that the board's decision (approval of the compensation package) is not protected by the "business judgment rule" the doctrine that shelters almost all board decisions from review. Both of these are difficult for shareholders to accomplish early in the litigation, especially because the plaintiff has not had the opportunity to conduct "discovery." 87

Consider the first approach: creating a reasonable doubt as to the independence of the board. To create such a doubt, one would generally need to show that the directors on the compensation committee have a direct financial interest in the compensation decision, or that they are beholden to the controlling person through personal or other relationships. ${ }^{88}$ Thus, by staffing the compensation committee with nominally independent directors, firms can in effect make it impossible for shareholders to satisfy the futility

84 See Randall S. Thomas and Kenneth J. Martin, Litigating Challenges to Executive Pay: An Exercise in Futility?, forthcoming, WASHINGTON UNIVERSITY LAW QUARTERLY (2001).

85 See Randall S. Thomas and Kenneth J. Martin, Litigating Challenges to Executive Pay: An Exercise in Futility?, forthcoming, WASHINGTON UNIVERSITY LAW QUARTERLY(2001).

86 Id. The failure of the board to deal with the demand in good faith or to conduct a reasonable investigation could constitute a wrongful refusal of demand, giving control over the litigation back to the shareholders. See id, at

87 See Randall S. Thomas and Kenneth J. Martin, Litigating Challenges to Executive Pay: An Exercise in Futility?, forthcoming, WASHINGTON UNIVERSITY LAW QUARTERLY (2001).

88 It is not sufficient to show, for example, that an executive whose pay is being challenged owned a large percentage of the firm's shares and personally selected the directors. See Aronson v. Lewis, 473 A.2d 805 (Del. 1983). 
requirement by creating a reasonable doubt as to the independency of the board. 89

The second approach to establishing demand futility -- showing that the board's decision is not protected by the business judgment rule -requires the plaintiff to provide evidence indicating that the board failed to fulfill either its "procedural due care" or its "substantive due care" duties. A board fails to fulfill its "procedural due care" duties by being uninformed. A board fails to fulfill its "substantive due care" duties by making an irrational decision and thereby committing "waste" or by making a "gift" unsupported by any consideration. However, the board can easily fulfill both types of duties. The board can satisfy its procedural duties by reading some materials and asking some questions. Similarly, it can easily meet its substantive due process duties by coming up with a justification for the executives' salary. Support can be marshaled for even the most patently unreasonable plans. ${ }^{90}$

If shareholders were to satisfy the demand futility requirement either by showing that the board was not independent or that the board likely violated its duty of care, they might still face additional obstacles before they could get to trial. In addition to (or after) arguing that the suit should be dismissed for failure to make demand, the board might also move to dismiss the suit for failure to state a legally recognized claim. It could then move to dismiss through a summary judgment motion, which would argue that the suit should be dismissed because plaintiffs have misinterpreted the law. Only after shareholders had overcome these hurdles could there be a trial. At trial, shareholders would still need to convince the court that the board violated its duty of loyalty or duty of care. If they could do so, the decision would then likely be appealed. ${ }^{91}$

89 Cf. Marx v. Akers, 666 N.E.2d 1034, 1036 (Ct. App. N.Y. 1996) (rejecting shareholders' demand futility claim on the ground that the compensation committee consisted of independent directors).

90 See Mark J. Lowenstein, Reflections on Executive Compensation and a Modest Proposal for Reform, 50 S.M.U. L. REV. 201, 214 (1996) (reporting that there have been no appellate court cases involving publicly traded firms affirming an order to reduce managerial compensation on the theory of gift or waste). See also Linda J. Barris, The Overcompensation Problem: A Collective Approach to Controlling Executive Pay, 68 INDIANA LAW JOURNAL 59 (1992).

91 Thomas and Martin compiled statistics on plaintiff's success rates at various stages of the litigation process when challenging management compensation of a publicly traded firm. See Randall S. Thomas and Kenneth J. Martin, Litigating Challenges to Executive Pay: An Exercise in Futility?, forthcoming, WASHINGTON UNIVERSITY LAW QUARTERLY (2001). They found that $47 \%$ of plaintiffs survive motions to dismiss for failure to make demand; $26 \%$ prevail in motions to dismiss for failure to state a claim; $28 \%$ survive motions for summary judgment; of these, 39\% win at trial and 39\% win at appeals. They calculate that if 
The recent case involving payments to a departing Disney executive, ${ }^{92}$ illustrates the hostility of courts to claims regarding executive compensation. In the process of hiring Michael S. Ovitz, the Disney board approved a "NoFault Termination" agreement with under which Ovitz would get, upon termination, a lump sum payment equal to the present value of all of the payments under his employment contract, an additional payment equal to "the product of $\$ 7.5$ million times the number of fiscal years remaining under the employment contract," and the immediate vesting of 3 million stock options for Disney shares. Not long after Ovitz began working at Disney, he quit, triggering the payments and vesting.

The fact pattern suggested that the board had been uninformed when approving the agreement with Ovitz and that the termination payments had little business justification. ${ }^{93}$ Shareholders sued the board. The Delaware Chancery court dismissed the suit on the ground that the shareholders did not show demand futility and failed to state a legally cognizable claim. The Supreme Court upheld the dismissal. The substantive merit of the case was never considered.

\section{The Rent Extraction View}

\section{Power and Rents}

The other view of executive compensation, the rent extraction view, also starts with recognition of the shareholder/management agency problem, but in this model executive compensation is seen as part of the problem rather than a remedy to it. Under the optimal contracting view, the board sets the compensation program to alleviate the agency problem between shareholders and executives. In contrast, under the rent extraction view, the executives, as part of the agency problem, influence pay levels to provide themselves with rent.

The rent extraction story picks up with our critique of the optimal contracting model. Under rent extraction corporate managers are firmly in control. The outside directors are connected to the executives by bonds of interest, collegiality, or affinity. These outside directors may rise up and displace a particularly poorly performing CEO, but short of this they will be strongly inclined to defer to and support the CEO's judgment. Given the substantial influence of the CEO and the CEO's management team over even

plaintiffs were forced to go through every stage of litigation, the likelihood of a successful outcome at the end of the process is $.52 \%$. See id at

92 Brehm v. Eisner, 746 A.2d 244 (Del. 2000).

93 See Randall S. Thomas and Kenneth J. Martin, Litigating Challenges to Executive Pay: An Exercise in Futility?, forthcoming, WASHINGTON UNIVERSITY LAW QUARTERLY (2001). 
nominally independent directors, bargaining over executive compensation does not approach the arm's length ideal. Rather, executives use their power to set a high level of compensation, and outside directors cooperate with management at least to some extent. ${ }^{94}$

The excess pay that executives are able to extract constitutes rent. It represents value that they capture due to their positional power. Specifically, the amount of rent that an executive extracts is the excess of the pay obtained by him over what he would have received under a contract that maximizes shareholder value. It is important to emphasize that the cost to the shareholders resulting from the extraction of rent might well be higher than the amount of the rent itself. To the extent that extraction of rent involves efficiency costs - due, in particular, to the adoption of compensation arrangements that are not efficient - the shareholders' loss will be larger than the rent extracted by managers.

This rent is received by the executive or team of executives in whose hands power is largely concentrated in a company with dispersed ownership. Many companies have a powerful CEO, and in those cases rent extraction will be concentrated in the hands of the CEO. In some companies power might be shared by a small team of top executives who together extract rent. Our discussion regarding extraction will refer to the rents captured by the powerful CEO or the executive team, as the case may be.

\section{The "Outrage Constraint"}

The rent extraction model does not imply that there are no constraints on compensation or the rent that executives can capture. The most important limit on executive compensation under this model likely would arise from what we will refer to as the "outrage constraint." Directors would be reluctant to approve, and executives would be hesitant to seek, compensation arrangements that might be viewed by observers as outrageous. ${ }^{95}$

${ }^{94}$ In this section we will present the rent extraction model as if it and optimal contracting were competing, mutually exclusive accounts of compensation. As will become clear in subsequent sections of the paper, we believe that both mechanisms play a role in the compensation-setting process of most firms.

${ }^{95}$ Jensen and Murphy, whose work we address later and whose approach to executive compensation is very different from ours, have also suggested that external perceptions might limit directors' ability to give executives large compensation packages. They refer to this limit as a "political constraint." See Michael Jensen and Kevin J. Murphy, Performance Pay and Top-Management Incentives, 98 J. POL. ECON. 225 (1990). Jensen and Murphy thus share our view that there are constraints on executive compensation imposed by the attitudes of persons outside the firm. The difference is that, as we discuss later, Jensen and Murphy believe that the optimal level of compensation might well be above the limit 
Crossing the outrage constraint could hurt directors and executives in several ways. First, violating outrage constraint might produce various social and reputational costs to directors. Although outside directors are willing to support and defer to executives, there is a limit to how far they will go. Professional reputation is very important to the typical outside director who does not join a board for the pay. In addition to the opportunity for intellectual challenge and stimulation, independent directors join for the prestige and connections that the posts give them. ${ }^{96}$ Hence, outside directors would be loath to approve a compensation plan that would embarrass them or compromise their reputations. ${ }^{97}$ Independent directors would be concerned about how such plans might be viewed by the media or various social or professional groups whose opinions are important to the directors. As a result, they would support management only insofar as the compensation proposal does not cross the outrage constraint.

Crossing the outrage constraint might also involve costs associated with an increased likelihood of being ousted in a control contest. Although limited reductions in corporate value are unlikely by themselves to trigger a takeover, outrageous compensation might lead to negative control effects. For example, institutional investors might view such compensation as a signal that the executives or directors are especially insensitive to shareholder interests and thus might be less willing to support the incumbents in a control contest. Given a weaker base of management support, a contest for control, through either a proxy contest or a takeover bid, might be more likely to arise.

Although a small group of observers - be they sophisticated market participants or researchers - might identify a compensation scheme as involving an especially egregious amount of rent, these observations by themselves would not constitute a violation of the outrage constraint. For executives or directors to be adversely affected in a material way through the channels discussed above, such observations need to be made by relevant groups, such as institutional investors en masse, the media, and/or social

established by these external constraints, whereas we believe that the optimal level of compensation is likely to be below this limit.

96 See JAY W. LORSCH AND EliZABETH M. MACIVER, PAWNS OR POTENTATES? THE REALITY OF AMERICA'S CORPORATE BOARDS 23-31 (1989) (responding to survey, outside directors reported that compensation was a relatively unimportant consideration in joining boards, while prestige and establishing contacts/enhancing business relationships were moderately important factors).

${ }^{97}$ Firms have been found to be responsive to financial press and institutional investor criticism of executive compensation arrangements. This finding is consistent with the existence of an outrage limitation on compensation. See Marilyn F. Johnson et al., Stakeholder Pressure and the Structure of Executive Compensation (working paper, 1997). 
and professional groups about whose views the executives and directors care. Therefore, violation of the outrage constraint greatly depends importantly on the extent to which rent extraction is clearly apparent to outsiders, not just (or even mainly) upon how much rent is extracted.

\section{The Critical Role of "Camouflage"}

Because of the importance of the outrage constraint, one prediction of the rent extraction view is that compensation plan designers will seek to camouflage the presence of rent extraction and conceal its magnitude. As we have discussed, a large amount of compensation will not by itself trigger the outrage constraint. Triggering will occur only if there is widespread recognition that the level of compensation is not the result of a contract designed in the shareholders' interest, but rather reflects a large extraction of rent. Thus, crossing the outrage constraint depends on the extent to which the rent extraction can be easily and distinctly identified. A large extraction of rent will not cause the executives or directors harm if it can be dressed, packaged, or hidden - in short, camouflaged - so that it is not readily apparent as such.

Accordingly, under the rent extraction view, managers will prefer compensation structures and processes that enable the extraction of rents to be camouflaged as optimal contracting, and efforts will be made to obfuscate the compensation data and otherwise plausibly justify the compensation programs. As we discuss in detail in Part III below, the outrage constraint and the resulting camouflage motive might explain why firms rely so heavily on compensation surveys and consultants. These tools might be used to explore and press the limits of justifiable compensation and to legitimize the compensation program selected, rather than to optimize the pay package. Furthermore, as we will examine in detail in Part IV, many aspects of existing compensation practice and design can be explained by considerations of camouflage.

One might ask how any observer can tell that rent extraction is taking place if it is camouflaged. To be sure, sometimes no observer will be able to do so, but the presence of camouflage does not imply that rent extraction will not be identifiable to any observer. For camouflage to be successful, as we discussed earlier, it need only prevent rent extraction from being easily identifiable to certain large groups of outside observers. Thus, it is in no way a contradiction for a researcher to view a certain compensation practice as being likely to include camouflaged rent. Such a judgment simply reflects the conclusion that the researcher has found to her own satisfaction that the compensation package or program is likely not to serve shareholders' interests, but rather to represent rent extraction. 
It is worth noting that the location of the outrage constraint and the methods of camouflage might change over time. When CEO's benchmark their compensation against each other and all aim to be at or above average, an upward ratcheting effect occurs. ${ }^{98}$ Furthermore, new and more performance-responsive compensation devices have tended to supplement rather than substitute for traditional compensation elements. ${ }^{99}$ Thus an executive pay plan that would have been considered patently unjustifiable ten years ago might produce below average compensation today. ${ }^{100}$ Under the rent extraction view, then, different equilibrium levels might arise.

Finally, it is important to emphasize that, because of the outrage constraint and the camouflage motive, there may be a significant overlap between rent extraction and incentive generation. Payments that are consistent with incentive generation might be relatively easy to justify and defend. The point of the rent extraction model, however, is that the executive compensation outcome would deviate from that which would be in the shareholders' interest. When rent extraction is at work, executives will receive more compensation than they would have received under an optimal principal-agent contract. Compensation structures may then be adopted that provide sub-optimal incentives but serve to increase executive wealth.

Rent extraction, then, can yield a deviation from optimality in both the magnitude and structure of executive compensation. The extent of that deviation, of course, is the critical issue. An adherent of the optimal contracting view would not be distressed to find that rent extraction leads to some minor deviation from the optimal contract. Our theoretical analysis, however, suggests that rent extraction may well play a major role.

\section{More and Less Power}

Because rent extraction is associated with managerial power, an important element of the rent extraction view is that there is a correlation between managerial power and rent. Executives generally have at least some power and therefore can extract at least some rent, but the particular characteristics of the firm, especially its ownership and board structure, give its executives more or less power. Under the rent extraction view, the greater the CEO's power, the higher the rent will tend to be.

98 See infra Part III.B.2.

99 See Tod Perry and Marc Zenner, Pay for Performance? Government Regulation and the Structure of Compensation Contracts (working paper, 1997).

100 While the U.S. executive pay baseline continues to rise, some external benchmarks have remained steadier. Thus, comparisons with executives of nonU.S. firms and U.S. shop floor to CEO pay multiples may play an increasingly important role in setting the outrage constraint. 
The power of the CEO will depend in large part on the ownership structure of the firm. The more shares owned by the CEO, the greater will be her influence on director elections and her ability to thwart or discourage a hostile takeover attempt. The more shares owned by unrelated parties, the less will be the CEO's influence on director elections and the more vulnerable the $\mathrm{CEO}$ will be to a hostile takeover attempt. Thus, the power of the CEO will tend to increase with the percentage of shares he owns, and tend to decrease with the percentage of shares owned by outside blockholders.

The CEO's power will also depend on the organization and composition of the board. Because a classified board makes a hostile takeover more difficult, a CEO's power will tend to be higher if the board is classified. The CEO's power will also depend on the number of inside directors and the number of outside directors. Also relevant is the number of outside directors over whom the CEO has some kind of influence. For example, an outside director might follow a CEO's wishes because he is a long-standing friend of the $\mathrm{CEO}$ or he is grateful that the $\mathrm{CEO}$ has placed him on the board.

We will discuss the correlation between managerial power and rent extraction in more detail, as well as present evidence of such a correlation, in Part IV.G. For now, however, it is worth pointing out that this element of the rent extraction view can explain much of what is observed in the world of executive compensation.

\section{Conforming to Norms}

In the last 10 years there has been much interest among legal scholars in the existence and evolution of "norms" and their effect on behavior in a wide variety of contexts. Recently, legal scholars have focused their attention on the effect of norms in the context of corporate law and corporate governance. ${ }^{101}$ It is thus natural to ask whether norms -- and in particular

101 See e.g., Margaret M. Blair and Lynn A. Stout, Trust Trustworthiness, and the Behavioral Foundations of Corporate Law, 149 UNIVERSITY OF PENNSYLVANIA LAW REVIEW 1735 (2001); John C. Coffee, Jr. Do Norms Matter? A Cross-Country Evaluation, 149 University of PENNSYlVANIA LAW REVIEW 2151 (2001); Robert Cooter and Melvin A. Eisenberg, Fairness, Character, and Efficiency in Firms, 149 UNIVERSITY OF PENNSYLVANIA LAW REVIEW 1717 (2001); Marcel Kahan, The Limited Significance of Norms for Corporate Governance, 149 UNIVERSITY OF PENNSYLVANIA LAW REVIEW 1869 (2001); Saul Levmore, Puzzling Stock Options and Compensation Norms, 149 UNIVERSITY OF PENNSYLVANIA LAW REVIEW 1901 (2001); Paul G. Mahoney and Chris W. Sanchirico, Competing Norms and Social Evolution: Is the Fittest Norm Efficient?, 149 UNIVERSITY OF PENNSYLVANIA LAW REVIEW 2027 (2001); Curtis J. Milhaupt, Creative Norm Destruction: The Evolution of Nonlegal Rules in Japanese Corporate Governance, 149 University of PENNSYlVANIA LAW REVIEW 2083 (2001); Edward B. Rock and 
the pressure to conform to norms -- might play a role in executive compensation.

As used in legal scholarship, the term "norms" has been used generally to refer to non-legal rules of conduct and behavior. Some norms simply reflect patterns of behavior that have arisen and tend to persist primarily because actors observe each other behaving in a particular way and believe that there is a potential cost to deviating from it. Suppose, for example, that every year the partners of $A B C$ law firm use law firm funds to give each of their secretaries a Christmas bonus. Beth, a partner at $\mathrm{ABC}$ law firm, learns that every other partner at $A B C$ law firm is going to give his or her assistant $\$ 500$ in cash. She must decide how much to give her assistant. If she gives less than this amount, her assistant might feel insulted. If she gives more, other partners might feel obligated to give a larger bonus next year lest their assistants feel insulted, and this may cause the other partners to resent Beth for "wasting" the firm's funds and reducing their profits. Thus Beth will have an incentive to stick to the established pattern of giving assistants a Christmas bonus of $\$ 500$ in cash.

The pressure to conform is likely to play an important role in executive compensation. At any given point in time, this pressure is likely to affect both the amount and structure of executive compensation arrangements recommended by compensation committees and approved by boards. As we have alluded to earlier and will discuss in more detail later, compensation committees recommend pay arrangements based in large part on the compensation packages they see at other firms. There is clearly a desire on the part of such committees and the board to conform to "the norm" or at least to be seen as conforming to the norm.

At the minimum, the desire to conform makes any movement from one equilibrium to another much slower and more gradual. Compensation committees' preference to conforming to the "norm" and fear of deviating substantially from it means that the evolution of compensation arrangements will take more time. Thus, whatever the nature of the current equilibrium, movement from it will be "sticky" due to the desire to conform to established patterns.

Michael L. Wachter, Islands of Conscious Power: Laws, Norms, and the Self-Governing Corporation, 149 UNIVERSITY OF PENNSYLVANIA LAW REVIEW 1619 (2001); Mark J. Roe, The Shareholder Wealth Maximization Norm and Industrial Organization, 149 UNIVERSITY OF PENNSYLVANIA LAW REVIEW 2063 (2001); David A. Skeel, Jr., Shaming in Corporate Law, 149 UNIVERSITY OF PENNSYLVANIA LAW REVIEW 1811 (2001); E. Norman Veasey, Should Corporation Law Inform Aspirations for Good Corporate Governance Practices - or Vice Versa?, 149 UNIVERSITY OF PENNSYLVANIA LAW REVIEW 2279 (2001). 
The main point we wish to emphasize is that the desire to conform to established patterns cannot provide a basis for a full account of executive compensation. The stickiness arising from the tendency to conform implies only that movement from one equilibrium to another will be very slow. It cannot explain why we are in a particular equilibrium to begin with. More importantly, given that patterns of executive compensation change over time, norms cannot tell us much about the new equilibrium to which we are heading, however slowly. To provide a full account of executive compensation, norms must be combined with another theory such as optimal contracting or rent extraction.

A theory combining norms and optimal contracting would predict that the evolution of executive compensation over time, although slowed by the tendency to follow established practices, is shaped overwhelmingly by the forces of optimal contracting. That is, as changing circumstances make the existing equilibrium suboptimal, boards induced by market pressure will move toward what would be the new optimal arrangement. Although the stickiness introduced by the desire to conform would prevent adjustment from being instantaneous, the forces of optimal contracting would be strong enough to ensure that this movement is fast enough that executive compensation does not deviate for a long time from what participants recognize to be the optimal arrangement.

In contrast, a theory combining norms and rent extraction predicts that the evolution of executive compensation over time is shaped, at least in part, by the desire of executives to extract more rents from their firms. When changing circumstances create an opportunity to extract additional rents -either by moving the outrage constraint or by giving rise to a new means of camouflage -- managers will seek to take full advantage of it and will push firms toward an equilibrium in which they can do so. However, the stickiness due to norms will slow this movement somewhat.

Thus, even though we recognize the importance of the pressure to conform we need another theory to explain why we are at the current equilibrium and what forces will move us to the next as circumstances change. That is, the question remains whether rent extraction can explain any aspects of current executive compensation practices and the direction in which these practices are headed.

\section{The Compensation LANDSCAPE As SEEn By the Two VIeWs}

We now turn to consider, in light of the alternative views of executive compensation that the preceding Part has outlined, the vast empirical evidence on the subject. We start the examination in this Part by discussing those features of the evidence that are consistent with both models. We 
describe how some basic features of compensation practices are viewed by each of the two perspectives. In Part IV, we will discuss evidence that can be better explained by the rent extraction view and thus suggests the presence of rent extraction.

\section{A. The Use of Executive Stock Options}

During the 1980s and 1990s, executive stock options became an increasingly important element of corporate compensation schemes, overtaking base salary as the largest single component of most executive pay packages. ${ }^{102}$ The increasing use of options has been a primary factor driving the ten-fold increase in CEO pay-for-performance sensitivity over the last two decades. One study of 1994 data from Forbes 500 firms determined that CEO salary and bonus were not significantly responsive to firm performance, while CEO stock and options holdings contributed roughly equally to pay-for-performance sensitivity. ${ }^{103}$ A more recent analysis found that annual cash compensation and long term performance plan payouts contributed as little as $2 \%$ to the sensitivity of CEO wealth to changes in shareholder value, while options contributed $46 \%$ and stock holdings

102 Murphy reports that option grants in manufacturing firms increased from 27\% to 36\% of total compensation between 1992 and 1996 alone. See Murphy, supra note 3. Yermack finds that on average options awards accounted for $20 \%$ of CEO compensation in 1984, 35\% in 1990, and 30\% in 1991. See David Yermack, Do Corporations Award CEO Stock Options Effectively?, 39 J. FIN. ECON. 237 (1995). Updating Yermack's data, Hall and Liebman report that 70\% of Forbes 500 CEO's received stock options in 1994, up from $30 \%$ in 1980, and that the mean value of options awarded to these CEO's increased from $\$ 155,000$ to $\$ 1.2$ million over this period. See Brian J. Hall and Jeffrey B. Liebman, Are CEO's Really Paid Like Bureaucrats?, 113 Q. J. ECON. 653 (1998). All of these studies utilized the BlackScholes methodology to value the option grants. Taking a different approach in a recent survey, the IRRC determined that the median S\&P 500 CEO received options worth $\$ 8.4$ million in 1998 based on an assumption of $10 \%$ appreciation in the stock price prior to exercise. See Kathy B. Ruxton, EXECUTIVE PAY, 1997 : CHIEF EXECUTIVE OFFICER COMPENSATION AT S\&P SUPER 1,500 COMPANIES AS REPORTED IN 1997 (Investor Responsibility Research Center, 1998). For a discussion of the dilution caused by the use of stock options and the cost to shareholders, see Jennifer N. Carpenter and David L. Yermack, Dilution from Stock-Based Compensation (working paper, 2000).

103 See Brian Hall and Jeffrey B. Liebman, The Taxation of Executive Compensation 22, NBER Working Paper 7596 (2000) (employing 1994 data and finding that an improvement from median to 70th percentile firm performance would increase the options-related wealth of the median Forbes 500 CEO by $\$ 0.85$ million and stock plus options-related wealth by $\$ 1.8$ million). 
contributed 51\%.104 This trend appears responsive to the long-standing demand of management experts and shareholder activists for a shift away from fixed compensation to performance-responsive pay practices. 105

The dramatic increase in the use of options in executive pay can be seen as the widespread adoption of a new compensation "technology." There is no question that this technology, if implemented properly, can improve managers' incentives and increase shareholder wealth. The issue is whether firms apply this technology in a manner optimal for shareholders.

\section{Using Options as Part of Optimal Contracting}

Proponents of optimal contracting generally see the increasing use of options as an unambiguously positive development. The optimal contracting school sees this compensation technology as good not only in principle but also in the way it has been applied. In their view these option plans provide increased market-based incentives for executives and bring total compensation packages closely in line with the optimal arrangement. ${ }^{106}$

104 See Tod Perry and Marc Zenner, Pay for Performance? Government Regulation and the Structure of Compensation Contracts (working paper, 1997). Slicing the data somewhat differently, Murphy finds that options and restricted stock accounts for $64 \%$ of the median 1996 pay-for-performance sensitivity among CEO's of S\&P 500 manufacturing firms, while stock holdings accounts for $31 \%$. See Murphy, supra note 3, at 83. See also John E. Core, et al., Are Performance Measures Other Than Price Important to CEO Incentives? (working paper, 2000) (finding that stock returns explain more than $90 \%$ of the total variation in CEO firm specific wealth).

105 Insensitivity of executive compensation to firm performance reportedly was one criteria employed by T. Boone Pickens' United Shareholders of America in its 1986-1993 campaign to improve corporate governance. See Deon Strickland et al., A Requiem for the USA: Is Small Shareholder Monitoring Effective?, 40 J. FIN. \& ECON. 319 (1996).

106 There is an extensive literature on the design of optimal compensation arrangements and related issues. See Li Jin, CEO Compensation, Diversification and Incentives (working paper, 2000); Frank Moers and Erik Peek, Managerial Risk Aversion and Executive Compensation: Measurement Issues and an Empirical Test (working paper, 2000) (developing and empirically testing proxies for managerial risk aversion); Tom Nohel and Steven Todd, Executive Compensation, Managerial Risk Aversion, and the Choice of Risky Projects (working paper, 2000); Tom Nohel and Steven Todd, Executive Compensation, Reputation, and Risk-Taking Incentives, (working paper, 2001); Tom Nohel and Steven Todd, Optimal Compensation for Risk-Averse Executives with Career Concerns (working paper, 2001); Yisong S. Tian, Optimal Contracting, Incentive Effects and the Valuation of Executive Stock Options (working paper, 2001). 


\section{Using Options to Extract Rent}

One adhering to the rent extraction view would not question that granting some options, by providing managers with more incentive to create shareholder value, might well be beneficial to shareholders. ${ }^{107}$ Rather, such a person would question whether the magnitude and design of a particular option-based pay package is optimal for shareholders. ${ }^{108}$ In other words, the issue is not the desirability of options in general, but how much should be given to executives and how these options should be structured. Although the introduction of options might well be a beneficial innovation that has yielded a useful incentive instrument, this innovation may also have increased executives' ability to camouflage rent and, as a result, their ability to extract more rents. On the rent extraction view, executives may have used the options bandwagon to extract rent.

And a major bandwagon it was: The 1990s boom in overall executive pay tracked the stock option boom. It is possible the widespread adoption of executive stock options has enabled executives to justify taking significantly larger amounts of value. One suspects the commentators and investors who advocated tying executive pay to performance envisioned shifting dollars out of straight salary and unresponsive bonus plans and into option or restricted stock plans. Average salary and bonus amounts have continued to rise, however, even as option awards have mushroomed. According to one study, from 1992 to 1998 the salary of the median S\&P 500 CEO increased by $29 \%$ to $\$ 811,000$ and the median bonus increased by $99 \%$ to $\$ 750,000$, while the median value of options grants rose by $335 \%$ to $\$ 1.6$ million. ${ }^{109}$ By

107 It is worth noting that an option grant can provide desirable incentives for managers only to the extent that managers who already own shares do not react to the option grant by selling a corresponding number of their existing shares. To the extent that managers offset the option grant with sales of existing stock, the option grant does not affect managers' incentives. See John Core and Wayne Guay, When Contracts Require Risk-Averse Executives to Hold Equity: Implications for Option Valuation and Relative Performance Valuation (working paper, 2001).

108 For theoretical analyses suggesting that an optimal compensation package should consist of only a relatively small amount of options, see Tom Nohel and Steven Todd, Optimal Compensation for Risk-Averse Executives with Career Concerns (working paper, 2001); Tom Nohel and Steven Todd, Executive Compensation, Reputation, and Risk-Taking Incentives (working paper, 2001).

109 See Perry and Zenner, supra note 1 . The option figures provided are based on an ex ante determination of grant date value based on a modified Black-Scholes methodology. See Tod Perry and Marc Zenner, Pay for Performance? Government Regulation and the Structure of Compensation Contracts (working paper, 1997). 
comparison, during this period the seasonally adjusted civilian employment cost index increased by $20 \%$ and the CPI increased by $16 \% .110$

According to these figures, median total CEO compensation increased by about $160 \%$ over this six-year period. ${ }^{111}$ It is conceivable that further increases in salary, bonus, and more traditional long-term incentive plans would have yielded a comparable increase in overall compensation in the absence of the options boom, but we are skeptical. Had option grants remained small and infrequent, salary, bonus, or long-term incentive plan payouts would have needed to increase much more rapidly to generate the same overall compensation boost. ${ }^{112}$ Using these numbers and holding option grant value steady at the 1992 figure, over \$1 million in added cash compensation would have been needed to achieve the same median overall compensation. We suspect that added cash compensation of this magnitude would have been much more salient and would have met with fierce resistance from investors, the media, and perhaps Congress. ${ }^{113}$

Of course large options grants have sparked public outcry as well, but we suspect for several reasons that the reaction to options has been more subdued than the reaction to cash would have been. Options enable rent extraction to be camouflaged for several reasons. First, options do provide executives with some useful incentives, and the value of these incentives is hard to estimate. Thus, even if the pay resulting from options appears inordinate, there would always be a facially plausible argument that the options serve shareholders' interests, whereas this would not be the case with a huge cash payment. Second, the value of stock options to the recipients is difficult to estimate; even finance experts sometimes disagree on the proper valuation methodology. ${ }^{114}$ Third, the media tend to focus on the

110 See Perry and Zenner, supra note 1, for the employment cost index figure. The CPI figure is from the Bureau of Labor Statistics database.

111 See id.

112 Were compensation bargaining arm's length, of course, we would not expect a dollar of options value to replace a dollar of salary because options represent risky compensation to the executive.

113 In 1993 Congress restricted corporations from deducting nonperformance-based compensation in excess of $\$ 1$ million paid to the CEO and the top four other mostly highly compensated executives. See IRC § 162(m).

114 See Jennifer N. Carpenter, The Exercise and Valuation of Executive Stock Options, 48 J. FIN. ECON. 127 (1998); Murphy, supra note 3; Steven Huddart and Mark Lang, Employee Stock Options Exercises: An Empirical Analysis, 21 J. ACCT. ECON. 5 (1996); Robert A. Lambert et al., Portfolio Considerations in Valuing Executive Compensation, 29 J. ACCT. RESEARCH 129 (1991). When the experts failed to agree on a valuation methodology, the predecessor to the FASB yielded and decided that standard executive stock options would not necessitate a charge to earnings. See GRAEF S. CRYSTAL, IN SEARCH OF EXCESS (1991). Meulbroek finds a large difference between the cost of stock options to a firm's shareholders (their market value) and 
gains reaped by executives on the exercise of options (the clearer figure) rather than on the value of the grants. This has enabled some executives to amass considerable paper wealth with little outcry. ${ }^{115}$ Fourth, compensation via options is paid out through stock dilution rather than cash. Fifth, while the FASB has required the disclosure of options grants to top executives, it has not required that the cost of most of these grants be taken into account for corporate earnings purposes. ${ }^{116}$ We shall discuss some of these features of option plan design in detail in Part IV.

\section{Possible Objections to the Rent Extraction View of Options}

Although the empirical evidence on the use of options is consistent with both the optimal contracting view and the rent extraction view, one might nevertheless find the optimal contracting view more appealing because (1) the increase in use of options coincided with the spectacular performance of the U.S. stock market over the last decade and (2) higher

the value of options to the often undiversified executives who receive them. She finds that undiversified executives of internet companies would value options at an average of only $53 \%$ of their cost to the company. Typical undiversified executives of NYSE companies, on the other hand, would value options at about $70 \%$ of shareholder cost. See Lisa K. Meulbroek, The Efficiency of Equity-Linked Compensation: Understanding the Full Cost of Awarding Executive Stock Options (working paper, 2000).

115 In a recent survey the IRRC reported that the median S\&P 500 CEO held unexercised in-the-money options worth $\$ 10.9$ million in 1998 and that two-thirds of these options were vested. In 1997 the median CEO had held unexercised options worth \$5.6 million. See Kathy B. RuXton, EXeCutive PaY, 1997: ChiEF EXeCUTIVE OfFICER COMPENSATION AT S\&P SUPER 1,500 COMPANIES AS REPORTED IN 1997 (Investor Responsibility Research Center, 1998).

116 We certainly are not the first observers to see the possibility of rent extraction in executive stock options programs. For example, Hall and Liebman suggest that the increase in options may result from a board's desire to pay CEO's more, but in a less visible fashion. They focus on the lack of an accounting charge. See Brian Hall and Jeffrey B. Liebman, The Taxation of Executive Compensation 22, NBER Working Paper 7596 (2000). Similarly, Lazear notes the perception that options are less apparent to shareholders than other forms of compensation. See Edward P. Lazear, Output-based Pay: Incentives or Sorting (working paper, 1999). Leonard suggests that misinformation may play a role in the adoption of option plans since the accounting rules do not value options correctly and payment is made via share dilution. See Jonathan S. Leonard, Executive Pay and Firm Performance, 43 InDUS. \& LABOR ReL. Rev. 13 (1990). See also Tom Nohel and S. Todd, Executive Compensation, Managerial Risk Aversion, and the Choice of Risky Projects (Feb. 2000) (suggesting that options may transfer wealth from stockholders to entrenched executives). 
equity ownership by managers is generally associated with better firm performance. As we explain below, however, these two observations are not at all inconsistent with the rent extraction explanation for the use of options.

(i) The Success of the U.S. Stock Market. As will be discussed later, options are more heavily used in executive pay in the U.S. than in other countries. Adherents to the optimal-contracting view might point to the outstanding performance of U.S. stocks over the past decade ${ }^{117}$ as evidence that the executive stock option boom has been a very good thing for shareholders. Such an inference would not be valid, however. It is difficult to establish a causal connection between the increasing use of executive stock options and steeply increasing price-to-earnings ratios given the many far more important factors that affect the overall level of U.S. stock prices. Inferring that U.S. corporate governance is superior on the basis of U.S. stock market performance over the past decade is no more valid than reaching the same inference with respect to Japanese and German governance structures based on the performance of those economies during the preceding decade. If such inferences cannot be drawn for corporate governance in general, surely they cannot be drawn with respect to the particular feature of the use of options.

(ii) Evidence that Equity Ownership by Managers Benefits Shareholders. There is considerable (although contested) evidence that equity ownership by managers of publicly traded firms with dispersed ownership increases firm performance. ${ }^{118}$ However, even if equity ownership by managers improves firm performance, studies linking managerial equity ownership to stock performance are actually of only limited relevance to the question of whether rent extraction can explain the use of option compensation.

First, the methodology of most of these studies measures the benefits of giving equity to managers but not the costs. The general approach of these studies is to examine managers' shareholdings at a particular point in time and then measure firm performance going forward. Such a study might find that the shares of firms whose managers own more equity (as a percentage of outstanding shares) outperform the shares of firms whose managers own less equity. However, if the shares had been provided as

117 The S\&P 500 index increased by 220\% between 1992 and 1998, but of course corporate earnings have not kept pace. See Perry and Zenner, supra note 1.

118 See Randall Morck, Andrei Shleifer, and Robert Vishny, Management Ownership and Market Valuation, 20 JOURNAL OF FINANCIAL ECONOMICS 293-315 (1988); John McConnell and Henri Servaes, Additional Evidence on Equity Ownership and Corporate Value, 27 JOURNAL OF FINANCIAL ECONOMICS 595-612 (1990). But see Claudio Loderer and Kenneth Martin, Executive Stock Ownership and Performance: Tracking Faint Traces, 45 J. FIN. ECON. 223 (1997) (finding no evidence based on a study of 1978 through 1988 data that greater stock ownership by executives improves firm performance but rather that firm performance affects how much stock the executives hold). 
compensation, they would have been provided by the firm before the measurement period had begun. Thus, the studies do not measure the cost of giving the managers those shares in the first instance. As a result, even if higher managerial equity ownership is associated with better firm performance, one cannot conclude from these studies that the benefit of giving additional equity to managers exceeds the cost to shareholders.

Second, the effect of managers' stock ownership on firm value is likely different than the effect of managers' option holdings on firm value. As is well understood, options and stock do not create the same effort and project choice incentives because there are different payoffs associated with each instrument. ${ }^{119}$ Thus, even if studies on the effect of managerial equity holdings on shareholder wealth took into account the cost of providing managers with that equity, these studies would still be of only limited relevance for answering the question of whether the use of options increases shareholder value.

In fact, the few studies focusing on the effect of options on shareholder value fail to demonstrate that adoption of option programs increases shareholder value. If anything, they suggest the opposite. One analysis of companies that adopted executive stock option plans between 1978 and 1982 determined that cumulative abnormal returns declined subsequently for two-thirds of the sample, that ROA declined absolutely and adjusted for industry, that $R \& D$ expenditure decreased, and that perquisite consumption increased. ${ }^{120}$ A more recent study examining publicly traded U.S. firms between 1992-1997 finds that CEO's hold too many options and shareholder value would increase if the number of options held by CEO's were reduced. ${ }^{121}$ Thus, the empirical data that is most relevant suggests that the use of option programs is consistent with rent extraction. paper, 2001).

119 See, e.g., Dirk C. Jenter, Understanding High-Powered Incentives, (working

120 See Richard A. DeFusco et al., The Association Between Executive Stock Option Plan Changes and Managerial Decision Making, 20 FIN. MGMT. 36 (1991).

121 Michel A. Habib and Alexander P. Ljungqvist, Firm Value and Managerial Incentives (working paper, 2000). Although this paper and the DeFusco et al study, supra note __, are the only two studies we have found that examine the effect of options programs on shareholder value, there have been a number of other studies that find that the use of options increase stock price and cash flow volatility. See, e.g., Richard A. DeFusco, R. Johnson, and T. Zorn, The Effect of Executive Stock Option Plans on Stockholders and Bondholders, 45 J. FIN. 617 (1990). The authors also found that options induce a transfer of wealth from bondholders to stockholders. Although such a transfer might benefit shareholders ex post, ex ante shareholders must pay for this transfer in the form of higher interest rates. For other studies showing that option-based pay causes managers to choose increase the volatility of cash flows and/or stock prices, see A. Agrawal and G. Mandelker, Managerial Incentives and Corporate Investment and Financing Decisions, 42 J. FIN. 823 (1987); Shivaram Rajgopal and Terry Shevlin, Early Evidence on the Informativeness of the 
(iii) The Devil is in the Details. It is important to emphasize that even if the use of options was found to be partially responsible for the excellent performance of the U.S. stock market during the last decade and that the adoption of an options program was found to boost a firm's stock price, one still could not rule out the role of rent extraction in the use of option compensation. The rent extraction view does not assert that the option programs adopted by publicly traded companies reduce share prices and make shareholders worse off. As we have just noted, the key issue is not whether options are a desirable innovation. It is how many options are given to executives and how those options are structured. Even if one were to accept that the use of options in general is beneficial to shareholders, many particular choices are made in the design of an option plan that may not be beneficial. Thus the key question is the design of the plans. We will focus on this critical question in Part IV, where we argue that many of the most prominent features of option grants - the use of non-indexed options, at-themoney strike prices, and reloads - are better explained by the rent extraction view, indicating that rent extraction plays a role in the design of option plans and practices.

\section{B. The Use of Compensation Consultants}

\section{Using Consultants to Search for Optimal Arrangements}

U.S. public companies typically employ outside consultants to provide input into the executive compensation process. ${ }^{122}$ Their use can be explained within the optimal-contracting framework. Compensation consultants may contribute to improving executive pay practices in two ways. First, they contribute expertise on the design of compensation packages. Second, they conduct compensation surveys and provide access to industry pay data that would not be shared directly between companies. ${ }^{123}$ This data, in turn, might be used to improve compensation packages. ${ }^{124}$

SEC's Market Risk Disclosures: The Case of Commodity Price Risk Exposure of Oil and Gas Producers, 74 AcCounting REVIEW 251 (1999); C. Schrand and H. Unal, Hedging and Coordinated Risk Management: Evidence from Thrift Conversions, 53 J.FIN. 979 (1998); Peter A. Tufano, Who Manages Risk? An Empirical Examination of Risk Management Practices in the Gold Mining Industry, 51 J. FIN. 1097 (1996).

122 See John M. Bizjack, Michael L. Lemmon, and Lalitha Naveen, Has the Use of Peer Groups Contributed to Higher Levels of Executive Compensation? (working paper, 2000 ) (reporting that at least $65 \%$ of firms use compensation consultants).

123 This data is provided in summary form only, of course. Firms participate in compensation surveys with the understanding that individual firm data will be kept confidential by the consultant. It is widely understood that compensation surveys have been responsible for the high degree of correlation between CEO pay 


\section{Using Consultants to Legitimize Compensation Arrangements}

The process through which pay consultants are retained and some evidence regarding their use, however, suggest an alternative explanation for the employment of these consultants that is in line with the rent extraction model: Managers might use compensation consultants primarily to justify executive pay, rather than to optimize it. As is the case with management domination over the board of directors, as we have discussed above, there is at least a risk of compensation consultant capture by management. Typically, compensation consultants are hired through a company's human resources department, and anecdotal evidence suggests that some CEO's are heavily involved in the process. ${ }^{125}$ Moreover, executive pay consultants often work for consulting firms that have other, larger assignments with the hiring company. This tends to undermine their objectivity. ${ }^{126}$

Through the use of surveys, pay consultants generate a mass of comparative compensation data that can be used to justify "objectively" a pay plan. Naturally, however, the output of this process depends in large part on survey design. One commentator argues that managers structure consulting assignments to focus attention on the compensation elements that will shed the most favorable light on executive pay and guide the selection of the peer group to accomplish the same end, and that compensation consultants go along with management's self-serving choices. ${ }^{127}$

Wade, Porac, and Pollack provide some evidence that companies use pay consultants and surveys strategically in justifying executive compensation. They find that companies that pay their CEO's larger base salaries and firms with more concentrated and active outside ownership are more likely to cite the use of surveys and consultants in justifying executive pay to the shareholders. ${ }^{128}$ The authors' other findings, for example, that accounting returns are stressed when they are high and that market returns

and company size. See George P. Baker et al., Compensation and Incentives: Practice vs. Theory, 43 J. FIN. 593 (1988).

124 As explained earlier, however, members of the compensation committee might feel pressure to conform to the pay practices at similar firms, regardless of their own view as to the desirability of those practices.

125 See Graef S. Crystal, In Search of Excess (1991). At least one institutional investor - TIAA/CREF - has suggested that compensation committees should be prepared to hire their own, independent executive pay consultants. See Fund Toughens on Executive Pay, InVESTOR RELATIONS Bus., Apr. 3, 2000.

126 See Graef S. CRYSTAL, IN SEARCH OF EXCESS (1991) (suggesting that employee benefits and other assignments often produce more revenue for a consulting firm than the executive compensation consulting assignment).

127 See id.

128 See James B. Wade et al., Worth, Words, and the Justification of Executive Pay, 18 J. ORG. BEHAVIOR 641 (1997). 
are de-emphasized when they are volatile, ${ }^{129}$ also are consistent with a view that executives, through the compensation committee, are working to throw the best possible light on their compensation. This lends further support to the notion that consultants and surveys are employed for the same purpose.

\section{The Limited Fraction of Value Paid to Executives}

Even with generous stock option plans, executives capture only a limited fraction of any increase in firm value. In an influential 1990 article, 130 Jensen and Murphy reported finding a statistically significant relationship between CEO pay and firm performance, but they argued that the fraction of increase in company value retained by CEO's was too small to be consistent with optimal contracting. The authors suggested that political constraints might account for the gap. Other commentators have argued that the sensitivity of pay-for-performance found by Jensen and Murphy can be reconciled with optimal contracting. In any event, more recent data indicate that the fraction of value retained by executives has increased dramatically over the last two decades. We conclude that the pay-for-performance sensitivity data are not inconsistent with either model of executive compensation.

\section{Claims that Executives Receive Too Small a Fraction of Value}

Using 1974 through 1986 data, Jensen and Murphy calculated that the median CEO of some 1300 companies included in Forbes' Executive Compensation Survey experienced a change in wealth of $\$ 3.25$ for each $\$ 1000$ change in shareholder value. ${ }^{131}$ Although they found that the relationship between pay and performance was statistically significant, Jensen and Murphy concluded that the incentives provided were insufficient to restrain executives from consuming excessive perquisites and generally maximizing their own utility at the expense of the shareholders. ${ }^{132}$ The authors

129 See id.

130 See Michael Jensen and Kevin J. Murphy, Performance Pay and TopManagement Incentives, 98 J. POL. ECON. 225 (1990).

131 See Michael Jensen and Kevin J. Murphy, Performance Pay and TopManagement Incentives, 98 J. POL. ECON. 225 (1990). The $\$ 3.25$ figure includes a $\$ 0.30$ adjustment for the increased risk of dismissal associated with a $\$ 1000$ drop in share value. See also Michael Jensen and Kevin J. Murphy, CEO Incentives: It's Not How Much, But How, HARV. BUS. REV. 138 (1990).

132 See Michael Jensen and Kevin J. Murphy, Performance Pay and TopManagement Incentives, 98 J. POL. ECON. 225 (1990). Jensen and Murphy determined that CEO incentives had deteriorated between the 1930s and 1980s in part because of a reduction in pay-for-performance sensitivity but primarily as a result of a reduction in the fraction of company shares held by CEO's. See also Michael Jensen 
speculated that political pressures prevent firms from adopting highly performance-responsive pay schemes that would result in high compensation for the very top performers. ${ }^{133}$ As a result, in the view of Jensen and Murphy, the financial rewards that executives receive in case of success are lower than would be optimal for shareholders.

\section{Defense of Existing Levels by Supporters of Optimal Contracting}

Several commentators writing from the optimal contracting perspective have disagreed with Jensen and Murphy's assessment of the performance sensitivity data. ${ }^{134}$ Hall and Liebman have argued that the \$3.25 figure is significant because the total wealth of a CEO of a large company will be quite sensitive to changes in firm value.135 Baker and Hall later refined this argument, explaining that the adequacy of the incentive depends on the class of decision at hand. ${ }^{136}$ When considering perquisite consumption, an executive simply will take into account the cost of the perk

and Kevin J. Murphy, CEO Incentives: It's Not How Much, But How, HARV. Bus. Rev. 138 (1990). But see Charles J. Hadlock and Gerald B. Lumar, Compensation, Turnover, and Top Management Incentives: Historical Evidence, 70 J. BUS. 153 (1997) (arguing that executive incentives under the control of the board of directors actually improved over the period in question).

133 See id. Although they concluded that executive pay-for-performance sensitivity was sub-optimal, Jensen and Murphy approached this problem from the optimal contracting perspective. They suggested that the optimal contract would arise between parties but for political constraints on the amount high-level performers could be paid. Cf. Paul Joskow et al., Political Constraints on Executive Compensation: Evidence from the Electric Utility Industry, RAND J. ECON. 165 (1996) (presenting evidence that political pressure constrains CEO pay in the electric utility industry).

${ }^{134}$ In addition to the papers that are discussed in the text, see Joseph G. Haubrich, Risk Aversion, Performance Pay, and the Principal-Agent Problem, 102 J. POL. ECON. 258, 258-276 (1994) (arguing that median pay-for-performance sensitivity observed by Jensen and Murphy is reconcilable with principal-agency theory given reasonable estimates of CEO risk aversion and other parameters). See also Bengt Holmstrom and Paul Milgrom, Multitask Principal-Agent Analyses, Incentive Contracts, Asset Ownership, and Job Design, 7 J. LAW ECON. \& ORG. 24 (1991) (suggesting that fixed pay can be optimal in situations where multiple tasks are required of an agent, particularly when measuring performance in various activities is difficult).

135 See Brian Hall and Jeffrey B. Liebman, The Taxation of Executive Compensation NBER Working Paper 7596 (2000).

136 See George P. Baker and Brian J. Hall, CEO Incentives and Firm Size (working paper, 1998). 
and the percent of the firm he "owns."137 Some decisions, however, such as the choice of resisting or supporting a takeover attempt, tend to have an effect that varies with firm size. With regard to these decisions, Baker and Hall argued, the value of the CEO's total equity stake will come into play, and large firm CEO's will be less likely to deviate from shareholder optimality. ${ }^{138}$

Other work demonstrates that the executive stock option boom of the last two decades has led to a dramatic increase in the sensitivity of executive wealth to company performance. One study found that in 1997 the median S\&P 1500 CEO stood to gain or lose $\$ 11.50$ for each $\$ 1000$ gain or loss in shareholder value. ${ }^{139}$ A more recent analysis, estimates average CEO wealthto-shareholder value sensitivity of approximately $\$ 11$ per $\$ 1000$, assuming a firm with a market capitalization of $\$ 1$ billion. ${ }^{140}$ Taken altogether, the payfor-performance data that have been generated might be consistent with the optimal contracting model, perhaps with some adjustment for political constraints.

137 See id. Here "percent owned" is used as shorthand for the measure of wealth to performance sensitivity, which can arise from shares owned, options held, or other performance related pay schemes. Using Jensen and Murphy's figures by way of example, the median CEO would weigh a $\$ 325$ personal cost in considering a $\$ 100,000$ perquisite expenditure.

138 See id. Consider, for example, the decision to support or resist a takeover at a $50 \%$ premium. The personal payoff to a CEO with $1 \%$ of a $\$ 10$ billion company obviously is ten times that of a CEO with $1 \%$ of a $\$ 1$ billion company. The cost to the displaced CEO due to loss of job, prestige, and pay also is greater in the first instance, but it probably is not an order of magnitude greater. See Murphy, supra note 3 (historically CEO pay increased 3\% for a 10\% increase in sales).

139 See Tod Perry and Marc Zenner, Pay for Performance? Government Regulation and the Structure of Compensation Contracts (working paper, 1997).

140 See Brian Hall and Jeffrey B. Liebman, The Taxation of Executive Compensation NBER Working Paper 7596 (2000). This estimate and that provided by Perry and Zenner exclude adjustment for risk of dismissal. See Tod Perry and Marc Zenner, Pay for Performance? Government Regulation and the Structure of Compensation Contracts (working paper, 1997). See also Paul L. Joskow and Nancy L. Rose, CEO Pay and Firm Performance: Dynamics, Asymmetries, and Alternative Performance Measures (working paper, 1994) (examining CEO pay from 1970 through 1990 and finding CEO compensation to be more sensitive to performance in the 1980s); Malcolm Baker and Paul A. Gompers, An Analysis of Executive Compensation, Ownership, and Control in Closely Held Firms (working paper, 1999) (finding that the sensitivity of CEO wealth to shareholder value among CEO's of firms undertaking IPO's is 50 times greater than that found by Jensen and Murphy). Comparing IPO firms with a broad sample of mature and new firms is a bit of an apples and oranges exercise. It would be interesting, however, to compare pay-for-performance sensitivity between size- and perhaps industry-matched samples of mature and IPO firms. 


\section{The Rent Extraction Perspective}

The pay for performance data, however, also appears to be consistent with the rent extraction view. It is impossible to determine the optimal payfor-performance sensitivity, and thus we cannot say whether option grants generally are sufficient today, nor can we dismiss the possibility that reduced grants might enhance shareholder value. ${ }^{141}$ Few incentives may be necessary to induce executive effort, and the form, rather than the amount, of incentives provided may be more important for inducing optimal effort and decision-making.

Second, and more important, even if executive pay is too insensitive to performance, we need not conclude that overall pay is too low and should be increased to raise pay-performance sensitivity. It might be the case that the overall level of executive pay could be reduced with either no effect or a positive effect on sensitivity by restructuring the form of compensation. We will discuss below how this could be done and why, because of rent extraction and camouflage, it might not be done.

\section{EVIDENCE BETTER EXPLAINED By RENT EXTRACTION}

This Part discusses important elements of the empirical evidence that better support the rent extraction view. We consider various compensation practices and patterns that are difficult to explain within the optimal contracting framework. Some of these practices and patterns have long puzzled researchers holding the optimal contracting view; we have identified others as posing problems for this view. Each of these practices and patterns, we believe, can be better explained by the rent extraction model, suggesting that rent extraction might be a significant phenomenon. In the aggregate, we suggest, these practices and patterns provide a solid basis for concluding that rent extraction is likely to play a significant role in the executive compensation process.

\section{A. Rewarding Executives for General Market Rises}

Although some firms include relative performance measures in their bonus programs, ${ }^{142}$ almost no companies include adjustments for industry or

141 As Murphy has noted, there is little direct evidence that increased payfor-performance sensitivity results in increased stock prices. See Murphy, supra note 3. We will return to this point below.

142 See Kevin J. Murphy, Performance Standards in Incentive Contracts, $30 \mathrm{~J}$. ACCOUNTING AND ECON. 245 (2001) (finding that only 21\% of S\&P 500 industrial 
market returns in the design of executive stock options, which, as we have noted, now represent the largest single component of the average executive's compensation package. ${ }^{143}$ Accordingly, an executive is rewarded for absolute share price increases, even if those increases are purely a function of broad market or sector increases. Thus, the executive might get a large payment from exercising his options and selling the stock regardless of the executive's contribution to the share price increase. Indeed, during the 1990s stock market boom, an executive might have made a large amount of money even if her firm's performance was worse than that of every other peer firm.

firms incorporated relative performance evaluation (RPE) in their 1997 bonus plans, while $57 \%$ of financial firms and $42 \%$ of utilities did so); Rick Antle and Abbie Smith, An Empirical Investigation of the Relative Performance Evaluation of Corporate Executives, 24 J. ACCT. RESEARCH 1 (1986) (examining the total after-tax compensation received by the three highest-paid executives in 39 firms over the period 1947-1977 and finding some evidence that the compensation is tied to relative performance of the firm); Robert Gibbons and Kevin J. Murphy, Relative Performance Evaluation for Chief Executive Officers, 43 INDUS. \& LABOR REL. REV. 30 (1990)(examining the compensation of 1668 CEO's from 1049 firms from 1974 to 1986 and finding some evidence the compensation is tied to relative performance). But see Surya N. Janakiraman et al., An Empirical Investigation of the Relative Performance Evaluation Hypothesis, 30 J. ACCT. RESEARCH 53 (1992) (examining CEO cash compensation from 609 firms from 1970 to 1988 and finding little evidence that RPE is used in determining such compensation); John E. Garen, Executive Compensation and Principal-Agent Theory, 102 J. POL. ECON. 1175 (1994) (examining the compensation of 415 CEO's in 1988 and concluding that there is little evidence of use of relative performance pay); Rajesh K. Aggarwal and Andrew A. Samwick, The Other Side of The Tradeoff: The Impact of Risk on Executive Compensation, 107 J. POL. ECON. 65 (1999)(finding no evidence of RPE in compensation in study of executive salaries during the period 1993-1996). Cf. Charles P. Himmelberg and R.G. Hubbard, Incentive Pay and the Market for CEO's: An Analysis of Pay-for-Performance Sensitivity (working paper, 1999) (arguing that the apparent absence of RPE is due to the inelastic supply of CEO's able to manage large enterprises, which causes CEO pay to increase with aggregate positive shocks to the market). There is some evidence that even though compensation is not based on RPE, relative performance is a better predictor of CEO firing than absolute stock price performance. See Jerold B. Warner et al, Stock Prices and Top Management Changes, 20 J. FIN. ECON. 461 (1988)(finding that in 269 publicly-traded US firms followed from 1962 to 1978, relative share performance was a better predictor of management turnover than absolute share performance).

143 See Murphy, supra note 3 (only one out of 1000 large public companies examined indexed the exercise price of options to market or peer performance); Joann S. Lublin, Pay for Outperforming, James Crowe, Chief of Level 3 Communications, Makes the Case for Linking Stock Options to Market-Beating Gains, WALL ST. J., April 6, 2000, at R8 (reporting on Level 3 Communication's use of S\&P 500 indexed options and noting that " $[\mathrm{t}]$ oday, no other public corporation takes such a daring approach to equity compensation"). 
Compensation dollars could be much better spent if executives received these dollars only to the extent that the increase in their firm's share price was due to firm-specific performance, and not sector- or broadermarket performance. There have been a number of proposals for such relative pay schemes. For example, as Alfred Rappaport has recently proposed in the Harvard Business Review, ${ }^{144}$ stock options should be designed with an exercise price that rises or falls with broader market movements. Alternatively, the exercise price of an option could be tied to the price of a basket of stocks in the firm's own industry. This would tie an executive's reward more closely to firm-specific performance that is within his control. ${ }^{145}$

Yet firms almost never employ options whose exercise price is somehow indexed to the performance of other firms in the industry or the market as a whole. Optimal contracting theorists have tried to explain the failure of companies to employ such indexed options but, as we will see, their efforts have not been very successful. This has led some prominent researchers in the field of executive compensation to declare that "the near complete absence of relative pay seems to be a puzzle."146 As we will show, however, this failure can be explained under the rent extraction view.

\section{The Benefits of (some form of) Indexing}

The optimal principal-agent contract should compensate the agent based on the achievement of objectives within the scope of his control. Since managerial effort essentially is unobservable and accounting results are noisy and fail to reflect the current value of growth opportunities, the share price of a firm provides a useful tool for evaluating executive performance.

However, compensation that is based on absolute share price performance rewards managers even when the managers' efforts have not contributed to the share price increase. In particular, the share price increase might be driven solely by factors external to the firm - such as changes in the economy that benefit the firm's industry or interest rate cuts that benefit the market as a whole. Because of such external factors, even managers who perform poorly -- and whose actions therefore stunt the increase in the price

144 See Alfred Rappaport, New Thinking on How to Link Executive Pay with Performance, HARV. Bus. REV., Mar.-Apr.1999, 91-101.

145 See, e.g., Shane Johnson and Yisong S. Tian, The Value and Incentive Effects of Non-Traditional Executive Stock Option Plans, 57 J. FIN. ECON. 3 (2000)(arguing that per dollar value indexed options create more powerful incentives than traditional options).

146 See Brian J. Hall and Jeffrey B. Liebman, Are CEO's Really Paid Like Bureaucrats?, 113 Q. J. ECON. 653 (1998). 
of the firm's stock -- can profit when their compensation is linked to changes in the absolute share price.

To be sure, the managers will be penalized if they add value but the stock price nevertheless declines because of changes beyond their control in the economy or the firm's sector. But such negative shocks are unlikely to take from managers as much as positive shocks will give them. First, while the economy and demand for the firm's products can contract as well as expand, over time it is reasonable to expect that these effects will be, on average, positive. Second, managers can never lose money from holding an option. The lowest payoff is $0 \%$. Thus negative economy- and industryshocks can never take away from the manager more than the firm specific value that he creates. For these two reasons, on an expected value basis the contribution of external market and sector forces to the value of the option is always positive.

From shareholders' perspective, the options plan should be designed to maximize incentives given the amount of dollars spent or to achieve a certain amount of incentive at the lowest possible cost. When managers are rewarded for market- and sector-wide price movements that have nothing to do with their efforts, the money is wasted. This raises the possibilities that the firm could either create the same incentive for less money or use the same amount of money to create even more powerful incentives.

The latter possibility is worth spelling out. If the firm gives the managers 1000 options to buy stock at the current market price of $\$ 100$, some of the expected value of the options -- and therefore some of the expected cost of the options to other shareholders -- comes from the fact that the stock price might increase for reasons having nothing to do with the managers' efforts but rather, say, because of unexpected reductions in interest rates. To the extent industry and market-wide effects boost the stock price, the manager will be "rewarded" for these increases when he exercises the options and shareholders will pay for this reward, even though this reward has no effect on the manager's incentives.

If we could design the scheme to remove or reduce the undeserved reward component of the option's value, we could at the same cost give the manager a larger number of differently structured options which would provide better incentives by linking the payoff more closely to the manager's efforts. Thus, significant benefits could be obtained from schemes that remove some or all of the reward to managers that has nothing to do with the manager's contribution to the stock price.

One approach that has received a great deal of support from academics and other commentators is that of "indexing" the exercise price of the option to the performance of the sector or the market as a whole to try to filter out changes in the stock price that are not due to the manager's efforts. Because the option could not be used to capture the expected increase in the 
stock price due to non-firm-specific effects, its expected value -- and its expected cost to shareholders -- would be lower.

By giving managers options that reward such managers only for increases in price that are firm-specific and thus more likely to result from their own efforts, a firm could, at the same cost, give more options to the managers and thereby increase their reward for creating value themselves. This, in turn, should induce more effort. Returning to our example, one might be able to give -- at the same cost as 1000 regular options -- 1500 options whose strike price is $\$ 100$ (the current market price) multiplied by, say, a market index. Under such a scheme, if the market has risen $30 \%$ since the options were granted, the exercise price would be $\$ 100 \times$ (1.30) or $\$ 130$. Using such a scheme would have the same cost to the firm but would provide stronger incentives. The index of course need not be the market - it could be the average performance of firms in the same industry. Using such an index would screen out not only broad market effects, but also effects associated with the firm's industry.

We should emphasize that standard indexing (either to the market or to a basket of peer firms) is not the only possibility. Suppose, for example, that one opposes indexing options to the average performance of peer firms because one believes that there are problems specific to the firm that are not of the CEO's doing which will limit the firm's performance in the short run. Or suppose the firm has no such problems but one is concerned that the CEO will have insufficient incentive to generate value if, in the middle of the vesting period, the $\mathrm{CEO}$ finds his firm ranked at the bottom of the industry and believes there is little he can do to bring the options into the money. Someone with these concerns could adopt a more "moderate" form of indexing where the exercise price is indexed not by the average performance of the industry (or the wider market) but by a certain fraction of it. Alternatively, one could tie the exercise price to the performance of the companies in, say, the bottom 25 th percentile of the industry. ${ }^{147}$

Note that such full or partial indexing may lead to the exercise price being lower than the market price at the time the options are granted. This would occur if the market or the industry (as the case may be) suffers a negative shock between the time the options are granted and when they are exercised. Whether the reduction in the exercise price gives managers more than they would have received under a regular options scheme would depend on whether those regular options would have been repriced. As we

${ }^{147}$ There are other approaches to screening out effects that are beyond the manager's control. See, e.g., Lisa K. Meulbroek, Executive Compensation Using Relative-Performance-Based Options: Evaluating the Structure and Costs of Indexed Options (working paper, 2001)(contending that an option whose exercise price is tied to a market or industry index does not completely filter out market or industry effects, and offering an alternative mechanism designed to do so). 
will see, such repricing is not uncommon. If the regular options would not have not been repriced, then the indexed options would make the managers better off. If the regular options would have been repriced to the indexed price or even lower, indexing would not make the managers better off. But even if the regular options would not have been repriced, because on average market and industry shocks are likely to be positive, the extra amount received when the index falls is unlikely to be as much as is taken away when the index rises.

Of course, one might want the exercise price to never fall below the market price at the time of issuance. In such a case, one could still take into account relative performance, but only on the upside. This could be done by using an exercise price that is the greater of the market price when the option is issued and the index-adjusted price. Any index could be used. Therefore one could tie the exercise price to the performance of the broader market, the industry, or some other set of firms, using average performance or any other metric, such as percentiles. The only situation in which this semi-indexed scheme would yield different results than regular options is when the index is in positive territory. In such cases, the payouts would be lower. However, by employing the semi-indexed scheme, the firm could use the expected savings from not rewarding the manager for changes beyond his control could be used to increase the number of options given at the grant-date and therefore boost performance incentives.

We want to stress that it is not our intention here to resolve the question of exactly how relative performance should be incorporated into option design. The optimal design may vary from industry to industry and perhaps even from firm to firm. We just want to point out that there is every reason to think that such schemes could generate better incentives for the same cost. ${ }^{148}$

148 There are other possible benefits to indexing that we have not touched on. For example, it is well understood that indexing the exercise price of options could eliminate an element of market uncertainty that creates risk for the executive who holds non-indexed options. See Bengt Holmstrom, Moral Hazard in Teams, 13 BELL. J. ECON. 324 (1982); Bengt Holmstrom, Moral Hazard and Observability, 10 BELL. J. ECON. 74 (1979) (arguing that even imperfect information can be used to improve upon a contract when effort is unobservable). But see Li Jin, CEO Compensation, Diversification and Incentives (working paper, 2000)(observing that indexing shifts market risk back to shareholders who might also be risk averse, and thus that from a pure risk-sharing -- i.e., non-incentive -- perspective the optimal contract might not involve indexing); John Core and Wayne Guay, When Contracts Require RiskAverse Executives to Hold Equity: Implications for Option Valuation and Relative Performance Valuation (working paper, 2001)(observing to the extent that a firm requires managers to invest in firm shares rather than use the funds to invest in the market nonindexed options expose the managers to market risk that they would 


\section{Optimal Contracting Explanations}

So why don't we observe indexed options? Financial economists have offered several explanations. As we will see, however, none of the explanations offered is fully convincing.

(i) Cost of Indexing. It has been suggested that it may be too costly to filter out industry or market noise through indexing. ${ }^{149}$ However, the economic cost of filtering does not seem to be a plausible explanation for the absence of indexed options. A wide variety of sector and broader market indices are reported daily in the Wall Street Journal and are available on-line from numerous sources. Moreover, the SEC's executive compensation disclosure regulations already require public corporations to select and present industry, line-of-business, or peer-group stock price performance data. ${ }^{150}$ Firms are thinking about the relevant indices and tracking this data already. Incorporating this information into their option plans would be trivial.

(ii) Encouraging Managers to Enter Other Industries. An alternative explanation that has been put forward is that the optimal agency contract might not involve filtering out industry noise. Shareholders, it is postulated, may prefer incentives that prompt executives to adapt to poor industry conditions, presumably by shifting company resources into more profitable sectors. 151 There are two problems with this explanation, however. First, it is not clear that investors want established firms to shift between industries. Investors can diversify across industries as they choose. Having decided to invest in an industry and to accept the sector-specific risk, diversified investors simply may want their firms to outperform the others in that sector. Second, and more fundamentally, even if investors are seeking maximum absolute performance rather than maximum performance within a sector, indexing remains advantageous. A firm that was concerned about this effect would employ a relatively broad index, such as the S\&P 500, rather than an industry-specific index. ${ }^{152}$

have been exposed to in any event). Our focus is on the fact that the random noise associated with non-indexed options has significant positive value.

149 See Surya N. Janakiraman et al., An Empirical Investigation of the Relative Performance Evaluation Hypothesis, 30 J. ACCT. RESEARCH 53, 53-69 (1992).

150 See Regulation S-K, Item 402 (l).

151 See Surya N. Janakiraman et al., An Empirical Investigation of the Relative Performance Evaluation Hypothesis, 30 J. ACCT. RESEARCH 53 (1992); cf. Ronald A. Dye, Relative Performance Evaluation and Project Selection, 30 J. ACCT. RESEARCH 27 (1992) (arguing that managers who are paid based on performance relative to their sector will prefer to operate in industries where their relative talent, not their absolute talent, is greatest).

152 Dye suggests that this phenomenon explains why implicit RPE studies have found that broad market price movements are more significant determinants 
(iii) Softening Industry Competition. Strategic considerations underlie a third explanation for the absence of indexed options. ${ }^{153}$ There is evidence that executive compensation is positively related to the performance of rival firms, particularly in industries that are subject to high levels of product competition, and it has been suggested that implicitly linking pay to rival firm performance in such cases serves shareholders by softening competition. ${ }^{154}$ But once again, while collusion among firms in competitive markets might explain the lack of sector indexing, the theory does not explain why these companies fail to index options against a broad market measure. And implicit collusion of this nature cannot explain the lack of indexing in highly competitive industries with low barriers to entry or industries in which competition comes from abroad. Finally, the limited evidence concerning explicit relative performance evaluation cuts against these strategic explanations: In annual incentive plans where we do observe such explicit evaluation, industry peer group comparison is overwhelmingly favored over broad-based comparison. 155 So the implicit collusion theory does not appear to offer strong support for firms' complete failure to index options.

(iv) Market Rises and CEO Shortage. Himmelberg and Hubbard offer a fourth explanation for firms' failure to filter out broad market effects. 156 They find evidence that CEO compensation is positively related to market returns and that the market effect on compensation is larger in larger firms. They argue that this evidence can be explained by the inelasticity in the supply of individuals who are qualified to run large firms. ${ }^{157}$ On their theory, the demand for executives rises when the economy is robust and

of compensation than are industry price movements. See Ronald A. Dye, Relative Performance Evaluation and Project Selection, 30 J. ACCT. RESEARCH 27 (1992).

153 See Rajesh K. Aggarwal and Andrew A. Samwick, Executive Compensation, Relative Performance Evaluation, and Strategic Competition: Theory and Evidence, 54 JOURNAL OF FINANCE 1999 (1999).

154 See id.

155 See Murphy, supra note 3 at Table 9 (reporting that only $10 \%$ of firms that employed RPE in annual incentive plans utilized a broad-based peer group measure).

156 See Charles P. Himmelberg and R.G. Hubbard, Incentive Pay and the Market for CEO's: An Analysis of Pay-for-Performance Sensitivity (working paper, 1999). See also Paul Oyer, Why do Firms Use Incentives That Have No Incentive Effects? (working paper, 2000) (presenting model in which it is optimal to pay individuals for group-level, industry-level, or economy-wide performance because agents' opportunities are correlated with aggregate performance and it is costly to adjust terms of employment contracts).

157 See Charles P. Himmelberg and R.G. Hubbard, Incentive Pay and the Market for CEO's: An Analysis of Pay-for-Performance Sensitivity (working paper, 1999). 
companies need to pay CEO's more to retain them. Allowing stock option rewards to increase with increasing market levels during boom periods responds to this need. CEO talent is more important and the supply less elastic in the case of large firms, they suggest, and for this reason large firms need to make executive pay even more sensitive to broad stock market levels. ${ }^{158}$

This theory, however, does not adequately explain standard compensation practices that tie executive incentives to broad stock price increases. Consider a company that signs a three-year contract with its CEO that gives the executive options that vest gradually over the three-year period. Suppose that the company seeks to address a scenario in which, after two of the three years, the economy booms, the stock market rises, and the executive is tempted to switch to a higher paying rival. Increasing the value of unvested options at this point to reflect the market upswing and hypothesized increased demand for CEO's might assist in retention. Twothirds of the options would have vested, however, and increasing the value of vested but unexercised options would further increase the executive's compensation without increasing the executive's opportunity cost of departing. If a company is concerned about retention in the foregoing scenario, establishing a mechanism through which executives are issued additional indexed options in the event of a market boom would be superior to granting non-indexed options.

(v) Excessive risk alteration. Saul Levmore has suggested a fifth explanation for the lack of indexing: "super-risk alteration." 159 According to Levmore, indexed options would encourage managers to differentiate their firms from the index in order to increase the likelihood that their options would be in-the-money. This, in turn, could cause managers to forego the best projects in favor of lower-value projects that have higher volatility (relative to the index). ${ }^{160}$

But even if indexing affects managers' choice of projects, it is not clear that indexing would overall worsen managers' decision-making. Indeed, it could have the opposite effect. It is well understood that risk-averse

158 See id.

159 See Saul Levmore, Puzzling Stock Options and Compensation Norms, 149 U. PENN. L. REV. 1901 (2001).

${ }^{160}$ Levmore acknowledges that the problem with indexed options he identifies cannot explain the failure to give indexed options to employees who either (1) do not have control over the firm's project choice and (2) are easily monitored. To explain the failure to give indexed options to these categories of employees, Levmore argues that a norm of "non-conflicting fortunes" prevents firms from distributing options in such a way that some employees' options would be in-the-money and others would be out-of-the-money. Thus, the need to give some employees (including the $\mathrm{CEO}$ ) conventional options requires that every other employee get conventional options. 
managers tend to prefer low volatility projects, even when they do not maximize the present value of the firm's assets. Options, which increase the reward to managers for choosing projects with more volatile distributions, give managers an incentive to choose riskier projects. Indeed, that is one of the reasons managers are given options in the first instance. However, there is no reason to believe that ordinary options completely overcome the effects of managerial risk aversion. Managers might still avoid some high-value but high-volatility projects. In such a case, if indexing were to affect managers' project choice it would overall improve the quality of projects chosen.

In addition, even if Levmore is correct that indexing would overall worsen the quality of projects selected by managers, it does not automatically follow that this effect would be sufficiently large to overcome the potential benefits of indexing - namely, the increased incentive to exert effort. Finally, even if the adverse effect suggested by Levmore were sufficiently large to outweigh the benefits of indexed-options in most cases, there is no reason to believe that indexed options would create worse overall incentives in every firm. Yet it appears that only publicly-traded firms uses indexed options. The potentially adverse risk alteration effects of indexed options is thus unlikely to account for their almost complete absence.

(vi) Tax advantage of non-indexed options. Sixth, David Schizer has identified a potential tax advantage of conventional options over indexed options that could, it is argued, be a partial explanation for the absence of indexing. ${ }^{161}$ As noted in Part II.B.1, since 1994 the annual pay of a CEO or top officer pay in excess of $\$ 1$ million has not been deductible by a publicly held corporation unless the excess compensation is performance-based: namely, the compensation is based upon the achievement of performance goals established by a compensation committee composed solely of independent outside directors. ${ }^{162}$ Both traditional and indexed options qualify as performance-based. ${ }^{163}$ However, because a traditional option does not screen out market- and/or industry-effects, the option provides some value to managers that is not performance-based. Thus, a traditional option offers non-performance-based pay that is exempt from the $\$ 1$ million deductibility cap. The tax benefit identified by Schizer would be useful to a firm that wishes to give a manager non-performance-based pay in excess of \$1 million, and prepared to give that pay in the form of a call on the market.

However, indexed options were rare even before this rule (which took effect in 1994) was enacted in 1993. Thus, Schizer acknowledges that this tax advantage cannot entirely explain the uniform use of traditional options.

161 See David M. Schizer, Tax Constraints on Indexed Options, 149 U. PENN.

L. REV. 1941 (2001).

162 See IRC § $162 \mathrm{~m}$.

${ }^{163}$ See David M. Schizer, Tax Constraints on Indexed Options, 149 U. PENN. L. REV. 1941, 1942 (2001). 
More importantly, it is not clear why, in an optimal contracting framework, a firm would wish to give a manager this type of tax-favored compensation. A call on the market (1) has no useful incentive effects for the manager and (2) because of its riskiness, is worth less to the manager than its cost to the firm. Thus, it is a highly inefficient form of compensation. The value of this call instead could be used to give the manager more indexed options and, therefore, greater incentive to generate value, at no additional tax cost to the firm.

(vii) The futility of indexing. Finally, it has been argued that indexing might be futile because managers can always make adjustments in their portfolios to offset the effect of indexing. 164 According to this argument, managers' outside investments generally are not restricted. If a manager is given indexed options (which, for example, screen out market effects), she can use personal assets to invest in the market portfolio in such a way that the combination of (i) the indexed options and (ii) her market portfolio investment generates the returns of a conventional, non-indexed option on her firm's stock. If such adjustments can be made, the argument goes, then there is no purpose to incurring transaction costs to create indexed options in the first instance.

To be sure, a manager given indexed options can invest her own funds in a benchmark portfolio, whose value is independent of the manager's efforts, that is designed to undo the indexing of her options. But this investment does not hurt the firm's shareholders. For the firm's shareholders, it matters little whether the manager uses her private funds to buy a benchmark portfolio designed to undo the indexing or some other set of stocks.

In contrast, shareholders would be hurt if the firm's funds were used to give the manager such a portfolio. Giving the manager such a portfolio would cost shareholders money and (by definition) have no effect on the manager's incentives. But in giving the manager a conventional option the firm in effect gives the manager such an offsetting portfolio. In particular, the firm gives the manager a combination of (i) an indexed option and (ii) the offsetting portfolio. Thus, when the firm's compensation dollars are used to give the manager unindexed options, some of those dollars are spent to give the manager compensation that is not likely to generate any value for shareholders.

In short, the ability of the manager to undo indexing through adjustment to her own portfolio does not mean that the firm should use its limited compensation dollars to give the manager compensation that is entirely unrelated to her performance.

${ }^{164}$ See Li Jin, CEO Compensation, Risk Sharing and Incentives: Theory and Empirical Results (working paper, 2000). 


\section{Is there an Accounting Constraint on Indexing?}

A final and very commonly voiced explanation for the lack of indexing deserves special attention. Most practitioners and many academics attribute the dearth of indexing, at least in part, to the unfavorable accounting treatment of these options. ${ }^{165}$ Under FASB rules, a company is not required to take a charge against earnings when it issues an option with a pre-determined exercise price and expiration date and that exercise price exceeds the fair market value of the stock at the date of the grant. ${ }^{166}$ Accordingly, traditional at-the-money (or out-of-the-money) stock options produce no corporate earnings charge, ever. Indexed options, however, lack a fixed exercise price and therefore fall outside of this charge-free zone. Companies issuing indexed options must mark these options against the market on a regular basis and accrue an earnings charge reflecting the appreciation in the value of the option over the indexed exercise price. So, the argument runs, traditional options are preferred over indexed options because the former result in higher reported earnings, which enhance share value. ${ }^{167}$

However, firms not reporting the actual cost of regular options as an expense are required to disclose via footnotes to their financial statements pro forma net income and earnings per share figures that include a fair value accounting adjustment for these options. 168

Given the pro forma disclosure requirement, one may question whether the "unfavorable" treatment of indexed options affects the stock price of a company that adopts these options. Are stock prices affected differently if an earnings charge appears in the income statement rather than in the footnotes? If stock prices reflect all publicly available information in accordance with the semi-strong form of the efficient capital markets hypothesis, ${ }^{169}$ the location of the disclosure does not matter, indexed options

165 See, e.g., Murphy, supra note 3 at 21; Brian Hall and Jeffrey B. Liebman, The Taxation of Executive Compensation 6, NBER Working Paper 7596 (2000) (reporting practitioners' assertion that option plans with "bad accounting" are not seriously considered).

166 See APB Opinion No. 25; RonALD L. GROVES, EXECUTIVE COMPENSATION 214.04 (1992).

167 To the extent that the managers' bonuses are based on reported earnings, higher earnings also increase the bonus. But presumably if the board was sophisticated enough to use indexed options, it would understand that the bonus formula would need to be adjusted to reflect the accounting effect of these options.

168 See Statement of Financial Accounting Standards No. 123 at 14.

169 See BREALEY AND MYERS, PRINCIPLES OF CORPORATE FINANCE (2000). 
are not more costly for firms, and the accounting difference is simply a red herring. ${ }^{170}$

If, on the other hand, the disclosure mechanism does affect a company's stock price, we must consider what inferences can be drawn from firms' failure to index. It may be that executives avoid indexed options and the corresponding charge to earnings because these charges have a negative impact on the firms' stock prices. If so, avoiding indexing might be in the shareholders' interest. ${ }^{171}$ But this would be the case only if (i) the market is inefficient; (ii) the market is sufficiently inefficient that there will be a substantial short-term decline in the price from moving to indexed options (in the long run, presumably, the stock price will reflect the fundamental value of the firm) ${ }^{172}$; and (iii) the cost of the short-term decline in share price to shareholders (who might sell in the interim for liquidity reasons) is greater than any direct benefit of an index scheme.

Note that it might be possible to achieve some form of indexing without adversely affecting accounting earnings. We put forward here for illustration two such mechanisms. There may well be others.

Begin by considering the following set of paired transactions. In the first transaction, the firm gives the CEO fixed-price options with an exercise price equal to the market price on the date of grant. As explained earlier, under FASB rules such a grant would not adversely affect accounting

170 Responding to the concern that investors may be misled by the company disclosing options expense only by footnote, Microsoft's CFO noted, "the Street figures it out pretty fast." See Laura Jereski, Share the Wealth: As Options Proliferate, Investors Question Effect on Bottom Line, WALL ST. J., Jan. 14, 1997, at A1. See also Alfred Rappaport, New Thinking on How to Link Executive Pay with Performance, HARV. BUS. REV., Mar.-Apr.1999 (arguing that accounting treatment of indexed options should be ignored for the reasons we have described). Some firms, however, do actively manage income through their accounting choices, and some weak evidence has been produced in support of the proposition that executive stock options are used by firms in preference to cash and in preference to incentive schemes with "bad accounting" as part of a broader income management strategy. See Steven R. Matsunaga, The Effects of Financial Reporting Costs on the Use of Employee Stock Options, 70 ACCT. REV. 1 (1995).

171 Inexplicably, some stock analysts apparently ignore options expense if the figure is not incorporated into earnings. See Laura Jereski, Share the Wealth: As Options Proliferate, Investors Question Effect on Bottom Line, WALL ST. J., Jan. 14, 1997, at A1 (reporting that "[i]n a recent survey of 300 top Wall Street stock analysts, eight of 10 said they would disregard stock options entirely, as long as companies don't have to take a charge for them"). Such survey evidence, of course, may tell us little about the actual incorporation of information disclosed in footnotes into stock prices.

172 There is considerable evidence that the market sees through obvious accounting manipulations, which suggests that many in the market would ignore the change in accounting earnings due to a one-time move to indexed options. 
earnings. Next, the CEO gives the firm the right to a payment equal to the excess, if any, of (a) an index over (b) the market price on the date of grant. The payment would become due if and when the CEO exercises his fixed price options. The second transaction creates an asset for the firm and thus presumably would not adversely affect accounting earnings. However, the two transactions together create a semi-indexed option that would remove the reward to the CEO from stock price rises that are sector- or market-wide and thus unlikely to be the result of the CEO's efforts. The money saved could be made available to shareholders or used to provide additional incentive options to the CEO.

A numerical example might be helpful. Suppose that $A B C$ Corporation's stock is trading at $\$ 100$. ABC would like to give the CEO 1000 options with an exercise price equal to the current market price multiplied by some index, say, the percentage appreciation of the market. Were ABC to give the $C E O$ such indexed options, FASB rules would require that $A B C$ mark the options to market and report an accounting expense whenever the stock price exceeds the exercise price. Instead, ABC could give the CEO 1000 regular options with a fixed exercise price equal to the market price, which under FASB rules would not result in an accounting charge. The CEO could then give $\mathrm{ABC}$ the right to payment of an amount equal to $1000 \times[\$ 100 \times(1+\max (\mathrm{M}, 0))-\$ 100]$ or, equivalently, $1000 \times[\$ 100 \times \max (\mathrm{M}, 0)]$, where $\mathrm{M}$ is the percentage appreciation of the market from the date of the option grant. The payment would become due whenever the CEO exercises his fixed price options. Thus suppose that on the date the CEO exercises his options the stock price is $\$ 150$ and the market has increased by $30 \%$. In such a case, the CEO makes $\$ 50,000$ exercising his options 1000 at a strike price of $\$ 100$, but this exercise triggers an obligation to pay $\$ 30,000$ to the firm. Thus, the CEO would net $\$ 20,000$ the amount by which the value of the options exceeded the index amount. The contingent obligation of the CEO should appear on $A B C^{\prime}$ s financial statement, if at all, as an asset, and should not give rise to an accounting charge.

The second indexing scheme does not involve creating a contingent obligation for the executive. Instead, tranches of fixed-price options are issued to the executive at every whole dollar stock price equal to or higher than the current market price. After the options vest, the executive would be permitted to exercise on any given day those options whose strike price corresponded most closely to the value of the index on that day. The remaining tranches of options would then be cancelled. This scheme would not adversely affect the firm's earnings because all of the options that have been issued have a fixed exercise price that is greater than or equal to the market price of the stock on the date of the option grant.

Again, suppose that $A B C$ 's stock is trading at $\$ 10$, and that $A B C$ would like to give the CEO 1000 options with an exercise price equal to the 
current market price multiplied by a market index. That is, $A B C$ wishes to give the CEO 1000 options with an exercise price of $\$ 100(1+\max (\mathrm{M}, 0))$. However, such options could trigger an accounting charge under FASB rules. Instead, $A B C$ issues 1000 options to the $C E O$ with a strike price of $\$ 100,1000$ options with a strike price of $\$ 101,1000$ options at a strike price of $\$ 102$, etc., all the way up to a strike price of say, $\$ 200$. On the date that the CEO wishes to exercise his options, he is permitted to exercise only those options whose strike price equals $\$ 100(1+\max (\mathrm{M}, 0))$.

In offering these two possible solutions to the problem of the accounting treatment of indexed options, we are not asserting that the FASB would treat the proposed option schemes as treats regular fixed-price options. The point is to show that there may be possible ways around the accounting constraint that firms could explore if firms wished to give CEO's indexed options without reporting a charge to earnings.

However, executives may be avoiding indexed options primarily because they believe the increased salience of the charge to earnings will draw additional negative attention to their option compensation. So, even if the method of disclosing options affects stock prices, we cannot be sure whether executives are avoiding indexed options to enhance shareholder value or to camouflage rent extraction.

Indeed, this fear of exposure may explain managers' fierce resistance to the FASB's attempt to rationalize options accounting. Financially, there is no plausible justification for the disparate treatment of indexed and nonindexed instruments, and the FASB attempted several years ago to impose a requirement that all stock-based compensation be accounted for on a rational and consistent basis, essentially in line with the current treatment of indexed options. ${ }^{173}$ Encountering heated resistance, the FASB stopped short of requiring firms to adopt its "fair value" method of option accounting and settled for enhanced disclosures.174 Companies that fail to adopt the new standards voluntarily and continue to employ the traditional accounting methods (i.e., essentially all firms) were required to disclose the information in footnotes, which is where we now stand. ${ }^{175}$

If options accounting matters, one can see why individual firms would not adopt a more stringent reporting mechanism voluntarily, but why would firms react so harshly to across-the-board imposition of such a logical

173 See Statement of Financial Accounting Standards No. 123.

174 See GRAFF S. CRYSTAL, IN SEARCH OF EXCESS (1991).

175 See Statement of Financial Accounting Standards No. 123 at 14 . The impact of these adjustments can be quite significant. Footnotes to Microsoft's 19951996 fiscal year income statement revealed that accounting for options would have reduced pretax income from $\$ 3.4$ billion to $\$ 2.8$ billion and earnings per share from $\$ 3.43$ to $\$ 2.85$. See Laura Jereski, Share the Wealth: As Options Proliferate, Investors Question Effect on Bottom Line, WALL ST. J., Jan. 14, 1997, at A1. 
change in accounting practice? As the FASB has noted, options have value, the award of valuable instruments to employees should be recognized as compensation expense, and the value of options can be estimated with sufficient accuracy for recognition.176 Moreover, the current irrational distinction between the accounting treatment of traditional options and all other forms of employee compensation apparently leads to distorted compensation practices. At the very least, one would have expected firms that rely less heavily on options to have supported FASB's proposal, and companies that rely more heavily on options to have opposed it. But the proposal received little or no corporate support.

The uniformly negative reaction of corporate America to the FASB's proposals does make sense, however, if executives are concerned primarily about increased visibility and increased negative reaction to their stock options. Whether he receives a relatively large option award or a relatively small one, no executive has an interest in having more attention drawn to his options.

\section{The Rent Extraction Explanation for Not Indexing}

While accounting treatment may play some role in option plan design, there is little doubt that if corporate America wanted to level the playing field between indexed and non-indexed options it could do so. Rationalization is, after all, one of the goals of the FASB. So we must continue to look deeper for the real barrier to indexing. We believe that the absence of indexed options fits in nicely with the rent extraction view of executive compensation. It is quite conceivable that executives choose to forego indexed options and utilize regular options because the latter are seen as legitimate and because they provide greater net value to their recipients.

First, regular options are legitimate. Although many commentators favor indexed options, 177 the use of non-indexed options generally is regarded as a legitimate and standard practice. Observers have begun to question the size of some regular option grants, but the design of these options appears to be well established and well accepted.

Second, using regular options instead of the same number of indexed options considerably increases executives' gains. We noted above, but did not explain in detail, that the expected value of a regular option is substantially greater than that of an indexed option. The non-indexed return on a stock is equal to the indexed return plus the market return. Since the market return has a substantial expected value for any given period, the value of a non-indexed option is much greater than that of an indexed

176 See Statement of Financial Accounting Standards No. 123 at 28.

177 See Alfred Rappaport, New Thinking on How to Link Executive Pay with Performance, HARV. BUS. REV., Mar.-Apr.1999. 
option. An executive of a company that performs no better than the market might receive no gains from an indexed option, but would receive substantial gains from a non-indexed option in any case in which the firm's stock price increases over time.

Thus, to switch to indexed options and maintain the same expected payout, considerably more options would have to be granted. However, if the size of the option grant, i.e., the number of options granted, is the most salient aspect of option awards to observers, outrage may be increased by switching to indexed options. Explicitly or implicitly, analysts continue to judge option grants by benchmarking them against the grants of other firms. To be sure, firms that adopt indexed options can attempt to explain to analysts and investors that the size of indexed and non-indexed grants are not comparable, but some observers may be skeptical, and the larger indexed option grants may draw unwarranted outrage. Thus, rent extraction considerations might be best served by using non-indexed options.

Of course, in certain situations indexing makes executives better off. In particular, if the index declines from the issue date to the exercise date, the exercise price will fall, increasing the profits from exercise of the option. As explained earlier, the amount by which executives would be made better off in such cases is likely to be less, on average, than the amount by which they would be made worse off when the index increases. However, executives are risk averse, and thus might be willing to make such a tradeoff. One might ask, therefore, why managers don't find this aspect of indexing sufficiently appealing.

The answer, we believe, is quite simple. As will be explained in Section C, when the stock price declines, executives might be able to get their options repriced at a lower exercise price. In such a case, they have ex post indexing on the downside. However, when the stock price increases for reasons unrelated to the CEO's performance, the options are not repriced at a higher price and the CEO gets to benefit fully. Thus the CEO is in the position of "heads I win, tails I don't lose." And this is better for the CEO than indexing, where there is a favorable adjustment on the downside but also an unfavorable adjustment on the upside.

\section{Implicit Relative Performance Evaluation}

Firms' failure to index options is very hard to reconcile with optimal contracting. Before moving on, however, we should consider whether evidence of implicit relative performance evaluation might explain or mitigate the omission. Implicit relative performance evaluation refers to the ability of companies to take relative performance into account ex post in adjusting bonuses and future salary, and in deciding whether to retain an 
executive. We conclude for three reasons that such implicit evaluation does not fill the gap left by firms' failure to index.

First, the evidence of implicit relative performance evaluation is far from overwhelming. A fair number of empirical studies have examined the relationship between executive compensation and relative firm performance. Gibbons and Murphy have offered support for the relative performance evaluation theory, finding that changes in CEO pay and the probability of CEO retention were positively and significantly related to firm performance, but negatively and significantly related to industry and broader market performance. ${ }^{178}$ But other studies have been less successful in finding evidence to support the implicit relative performance evaluation hypothesis. One analysis found little evidence of relative evaluation in the cash compensation paid to CEO's over the 1970 to 1988 period. ${ }^{179}$ In two studies, Aggarwal and Samwick found evidence flatly inconsistent with the theory. ${ }^{180}$ In one study, they found executive compensation to be positively related to rival firm performance. ${ }^{181}$ Also inconsistent with this hypothesis, at least to some extent, is the evidence that CEO compensation increases with relative

178 See Robert Gibbons and Kevin J. Murphy, Relative Performance Evaluation for Chief Executive Officers, 43 INDUS. \& LABOR REL. REV. 30 (1990) (examining 19741986 data); Jerold B. Warner et al, Stock Prices and Top Management Changes, 20 J. FIN. ECON. 461 (1988) (finding that top management changes are better predicted by relative firm performance than by absolute firm performance). Several earlier studies found evidence of a correlation between CEO compensation and relative stock returns, but the evidence generally was weak. See, e.g., Rick Antle and Abbie Smith, An Empirical Investigation of the Relative Performance Evaluation of Corporate Executives, 24 J. ACCT. RESEARCH 1 (1986) (finding evidence consistent with the RPE hypothesis among less than half of the firms analyzed); Kevin J. Murphy, Corporate Performance and Managerial Remuneration: An Empirical Analysis, 7 J. ACCT. ECON. 11 (1985); Anne T. Coughlan and Ronald M. Schmidt, Executive Compensation, Management Turnover, and Firm Performance: An Empirical Investigation, 7 J. ACCT. ECON. 43 (1985).

179 See Surya N. Janakiraman et al., An Empirical Investigation of the Relative Performance Evaluation Hypothesis, 30 J. ACCT. RESEARCH 53 (1992); John E. Garen, Executive Compensation and Principal-Agent Theory, 102 J. POL. ECON. 1175 (1994) (finding little evidence of implicit RPE); Martin J. Conyon, Corporate Governance and Executive Compensation, 15 INT'L J. INDUS. ORG. 493 (1997).

180 See Rajesh K. Aggarwal and Andrew A. Samwick, Executive Compensation, Relative Performance Evaluation, and Strategic Competition: Theory and Evidence, 54 JOURNAL OF FINANCE 1999 (1999); Rajesh K. Aggarwal and Andrew A. Samwick, The Other Side of The Tradeoff: The Impact of Risk on Executive Compensation 107 J. POL. ECON. 65 (1999).

181 See Rajesh K. Aggarwal and Andrew A. Samwick, Executive Compensation, Relative Performance Evaluation, and Strategic Competition: Theory and Evidence, 54 JOURNAL OF FINANCE 1999 (1999). 
firm performance but increases more significantly with increases in market returns. ${ }^{182}$

Second, even if there were strong evidence of a correlation between firm-specific performance and executive pay, this would not necessarily imply a significant dollar effect for the executives and a significant degree of relative performance evaluation. Stock options are driving executive compensation and these options are not indexed, although they easily could be. Thus, a finding that executive salaries vary to some extent with firmspecific performance would not be convincing evidence of optimal relative performance evaluation and would not explain why stock options - the dominant compensation element - would not be subject to relative performance evaluation.

\section{B. Uniform Use of At-the-Money Options}

An analysis of options granted to the CEO's of 1000 large companies in 1992 determined that $95 \%$ of the options were granted at-the-money, that is, with an exercise price equal to the company's stock price on the date of the grant. 183 No one has provided a convincing explanation for this phenomenon, which Hall and Murphy call "striking."184

\section{The Puzzle for the Optimal Contracting View}

There is a debate in the literature as to the optimal exercise price for executive stock options, and researchers have identified various factors that might be relevant for this question. ${ }^{185}$ It is highly unlikely, however, that a

182 See Charles P. Himmelberg and R.G. Hubbard, Incentive Pay and the Market for CEO's: An Analysis of Pay-for-Performance Sensitivity (working paper, 1999).

183 See Murphy, supra note 3.

184 See Brian J. Hall and Kevin J. Murphy, Stock Options for Undiversified Executives 2 (working paper, 2000).

185 Options normally encourage executives to take on additional risk. See, e.g., Kevin J. Murphy, Performance Standard in Incentive Contracts, 30 JOURNAL OF ACCOUNTING AND ECONOMICS 245 (working paper, 2000). Because most managers are under-diversified and risk averse, it generally is assumed that encouraging executives to take on additional risk is positive for shareholders. See Richard A. DeFusco et al., The Effect of Executive Stock Option Plans on Stockholders and Bondholders, 45 J. FIN. 617 (1990). But option awards produce complex and dynamic incentives. Certain option designs may cause executives to take on too much or too little risk, and the incentives vary as options move in and out of the money. Under certain assumptions about managerial risk aversion, managers' reservation utility, and project choices, it is possible to show that at-the-money options are optimal. See Tom Nohel and Steven Todd, Optimal Compensation for Risk-Averse Executives with 
single design would be optimal for all companies and all executives. ${ }^{186}$ Option values and the incentives they create depend on a stock's volatility, the grantee's stock holdings, and the grantee's general level of risk aversion. ${ }^{187}$ Moreover, the shape of the desired incentive will depend on a firm's growth opportunities, debt load, and other factors. ${ }^{188}$ These variables will differ from firm to firm or even from executive to executive. ${ }^{189}$ Thus,

Career Concerns (working paper, 2001). But under other assumptions at-the-money options are not optimal. See Tom Nohel and Steven Todd, Executive Compensation, Managerial Risk Aversion, and the Choice of Risky Projects (working paper, 2000). Cf. Tom Nohel and Steven Todd, Executive Compensation, Reputation, and Risk-Taking Incentives, (working paper, 2001) (showing that in-, at-, or out of the money options can align incentives depending on the circumstances). Some analysts conclude that at-the-money options provide managers with suboptimal pay-for-performance incentives. See Brian J. Hall, A Better Way to Pay CEO's?, in EXECUTIVE COMPENSATION AND SHAREHOldER VAlUE, 35 (J. Carpenter and D. Yermack, eds., 1999) (arguing that some firms could improve their executive compensation practices by adopting out-of-the-money and indexed options, which provide greater sensitivity to performance than at-the-money options); Shane A. Johnson and Yisong S. Tian, The Value and Incentive Effects of Nontraditional Executive Stock Option Plans, 57 J. FIN. ECON. 3 (2000)(arguing that premium options create more powerful incentives than at-the-money options of equal value); Robert A. Lambert et al., Portfolio Considerations in Valuing Executive Compensation, 29 J. ACCT. RESEARCH 129 (1991) (arguing that options that are very likely to wind up in the money actually increase executive risk aversion); David Brookfield and Phillip Ormrod, Executive Stock Options: Volatility, Managerial Decisions, and Agency Costs, 10 JOURNAL OF MULTINATIONAL FINANCIAL MANAGEMENT 275 (2000).

186 See Yisong S. Tian, Optimal Contracting, Incentive Effects and the Valuation of Executive Stock Options 40 (working paper, 2001) (arguing that the optimal exercise price depends on the level of risk aversion and could be in-, at-, or out-of-the money depending on the executive and concluding that the uniform practice of granting atthe-money options is not supported by principal-agent theory).

187 See Tom Nohel and S. Todd, Executive Compensation, Managerial Risk Aversion, and the Choice of Risky Projects 7 (working paper, 2000).

188 See Chongwoo Choe, Executive Stock Options and Investment Choice (working paper, 1999). Cf. Harley E. Ryan Jr. and Roy A Wiggins III, The Influence of Firm-and Manager-Specific Characteristics on the Structure of Executive Compensation, 7 J. CORP. FIN. 101 (2001) (finding that CEO compensation is affected by such firm specific factors as R\&D and capital expenditure intensities and such managerspecific factors as the CEO's age).

189 See Lisa K. Meulbroek, The Efficiency of Equity-Linked Compensation: Understanding the Full Cost of Awarding Executive Stock Options (working paper, 2000). Meulbroek estimates that a typical undiversified executive of an internet company values standard stock options at only about $53 \%$ of the options' cost to shareholders, while the typical undiversified NYSE executive values options at about $70 \%$ of their cost. A partially diversified executive of these two classes of companies would value options at about $59 \%$ and $88 \%$ of their cost to shareholders, 
there is no reason for the optimal exercise price to be the same for all companies.

It is difficult to explain the uniform use of at-the-money options within an optimal-contracting framework. Options that are granted in-themoney do have to be taken into earnings, whereas at-the-money and out-ofthe-money options do not. As we explained in the previous section, however, unfavorable accounting explanations of company behaviors are not fully convincing. Moreover, this explanation fails to explain the uniformity observed unless one believes that out-of-the-money options never are optimal. 190

While many have noticed that there is near-uniformity among the exercise price of options, little attention has been given to the fact that there are actually two dimensions along which this uniformity occurs: (1) any given firm will use the same exercise price for options regardless of the vesting period of the option - e.g., an option that vests in a year has the same exercise price as an option that vests in five years; and (2) almost all firms use the same formula for determining this exercise price, namely, the current market price.

The literature has, as we saw earlier, focused on the second pattern. But it has not fully considered the first - that exercise prices are uniform across vesting periods. Note that since prices go up on average, an option that is issued at the current market price is likely to be in the money in the future and its effect on effort then would be equivalent to the effect on effort today of an option that is in-the-money today. We certainly do not attempt

respectively. Her analysis strongly suggests that one-size-fits-all option plans are suboptimal.

190 In recent work, Hall and Murphy use numerical simulations in an attempt to derive optimal exercise prices under various assumptions about the shape of managerial utility functions, managerial wealth, the stock market return, and the volatility of the firm's stock. Under a range of parameters, they show that the exercise price that maximizes pay-for-performance sensitivity is usually in a range that includes the current market price. See Brian J. Hall and Kevin J. Murphy, Optimal Exercise Prices for Executive Stock Options, 90 AMERICAN ECONOMIC AsSOCiATION PROCEEDINGS 209 (2000). See also Brian J. Hall and Kevin J. Murphy, Stock Options for Undiversified Executives 20-22 (working paper, 2000). However, their analysis cannot explain why, as they report, $94 \%$ of option grants are at-themoney. First, there is no evidence that the utility functions they use -- which are designed to make their calculations tractable -- correspond to those of actual managers. Second, the analysis does not take into account the incentive effects of the options on managerial behavior and the stock price. Third, even if their parameters corresponded to the situations of actual CEO's and incentive effects could be ignored, their parameters generate a range of optimal exercise prices, some of which (under certain conditions) are out-of-the-money. Yet almost all option grants are at-the-money. 
to try to analyze here what would be the optimal exercise price of options that are going to vest a number of years from now. This might depend on the time value of money and the rate of inflation. An option exercisable at the current market price that vests in 5 years will in real terms have an exercise price much lower than the current market price. But the important point is that there is little reason to think that the optimal formula would be not only uniform across companies but also uniform across vesting periods.

\section{The Rent Extraction Explanation}

Under optimal contracting, the exercise price of options should be set to maximize shareholder value and since there is reason to believe that the value-maximizing exercise price might differ across vesting periods and across firms, the uniformity along both dimensions poses a puzzle. Under the rent extraction view, however, the near-uniform use of at-the-money executive stock option plans can be easily explained. Under that view, managers are not seeking exercise prices that are value-maximizing for shareholders but rather exercise prices that are value-maximizing for managers - namely, the lowest possible exercise price consistent with other constraints.

At-the-money options might well provide the best combination of high rent extraction and low outrage. Holding the number of options granted equal, executives prefer the lowest possible exercise price. Each dollar of strike price reduction is a dollar gained once the option is in the money. Thus, executives prefer an option that bears the lowest possible strike price without causing outrage. Granting in-the-money options would appear to provide a gift to the executives - "incentive" compensation that requires no improvement in performance - and thus would likely spark outrage. Providing at-the-money options, however, can be justified on the basis of incentive generation. The empirical observation that exercise prices are uniformly tied to the company's stock price on the date of the grant, regardless of the length of the option contract, the type of company, and the stage of the executive's career - all factors relevant for economic optimization - is most consistent with a constraint based on saliency and outrage. ${ }^{191}$

191 The number of options issued also is quite salient. The size of option grants generally is determined through surveys and benchmarking. Thus, increasing the size of an option grant to adjust for a higher strike price may produce outrage even if the increase is justified economically and represents a fair tradeoff for shareholders. This phenomenon also would encourage executives intent on maximizing rent extraction to select the lowest justifiable option exercise price. 
In addition, the grant of in-the-money options would force the firm to reduce accounting earnings by the amount by which the options are in-themoney. As we noted earlier, we are skeptical about the force of the accounting explanation for the lack of indexing. Rather, we think that firms use accounting effects as an excuse for not indexing. However, firms could not use in-the-money options with their adverse accounting effects and still maintain that adverse accounting effects prevented them from using indexed options.

Because setting the exercise price below the current market price might create outrage and strip away one of the excuses for not indexing, it is not surprising that exercise prices are set at the lowest possible price current market price - and that those prices are used regardless of the vesting period.

\section{Resetting of Option Exercise Prices}

In many cases corporations have lowered the strike prices of options when their stock prices fell below the original exercise prices, but firms have rarely raised strike prices in a rising market. This one-sided practice of resetting is yet another feature of option practice that is puzzling from an optimal contracting perspective, but consistent with the rent extraction view.

Although not universal, the practice of resetting was fairly common in the 1990s, even though the market as a whole was performing well. Examining the S\&P ExecuComp database for 1992-1995, Brenner, Sundaram and Yermack found that, on average, 1.3\% of executives had options reset each year. ${ }^{192}$ Of 806 individual option resets, they found that the strike price was increased in only two cases, and they calculated an average reduction in exercise price of $39 \% .{ }^{193}$ It is worth noting that the S\&P 500 Index rose by about $50 \%$ during the period studied by the authors, with no significant downturns. The frequency of resetting is likely to be much higher in falling markets.

\section{The Resetting Puzzle}

Ex post adjustments to compensation contracts have troubling implications that make them difficult to explain within an optimal

192 See Menachem Brenner et al., Altering the Terms of Executive Stock Options, 57 J. Fin. ECON. 103 (2000). See also KATHy B. RuXTON, EXECUTIVE PAy, 1997: CHIEF EXECUTIVE OFFICER COMPENSATION AT S\&P SUPER 1,500 COMPANIES AS REPORTED IN 1997 (Investor Responsibility Research Center, 1998) (finding that 3\% of 1189 firms surveyed by the IRRC repriced options in 1998).

193 See Menachem Brenner et al., Altering the Terms of Executive Stock Options, 57 J. FIN. ECON. 103 (2000). 
contracting framework. Clearly, the expectation that firms will adjust ex post for adverse stock price movements undermines ex ante incentives. Thus, the practice of $e x$ post resetting undermines the goal that underlies the very use of stock option plans. ${ }^{194}$ Indeed, when executives anticipate that the exercise price will be reset if the stock price falls they may have an incentive to take steps to reduce the share price in the short run in order to lower the exercise price. ${ }^{195}$

Companies claim that these adjustments are necessary to retain and motivate executives when prices fall to levels that make existing options far out-of-the-money. Although ex post resetting undermines ex ante incentives to some extent, so the argument goes, companies may determine that, on balance, these ex post retention and incentive benefits outweigh the ex ante costs. ${ }^{196}$

Even when a fall in stock market price eliminates incentives, however, optimal contracting suggests that companies should adjust option terms to provide better incentives going forward and not merely to transfer value to recipients. If exercise prices are reset, for example, vesting periods should be reset as if the options were granted on the date the exercise price is reset. There is no incentive or retention reason to give executives any benefit from fully or partially vested options that have lost their value. Any such benefit would therefore constitute a windfall.

It has been argued that, even if resetting is undesirable following a company-specific price decline, it might be appropriate after a general market downturn, because such an event is outside of the executives' control and the executives will add a large risk premium if there is no agreement to adjust for general market corrections. ${ }^{197}$ But repricing regular options in the wake of a market downturn appears to be a second-best result compared with indexing the options against market movements in the first place. Ex post adjustment to the terms of indexed options that automatically correct for sector-wide, or at least market-wide, shocks generally will be less necessary, and it certainly will be more difficult to justify.

Consider two regimes. In the first, executives receive regular options and fall back on resetting when the market moves against them. This arrangement allows the executives to reap the gains that come with a market-wide rally, even if the rally simply offsets an earlier market slide. So

194 See Viral V. Acharya et al., On the Optimality of Resetting Executive Stock Options, 57 J. FIN. ECON. 65 (2000)

195 See Shane Johnson and Yisong S. Tian, The Value and Incentive Effects of Non-Traditional Executive Stock Option Plans, 57 J. FIN. ECON. 3, 17 (2000).

196 See Viral V. Acharya et al., On the Optimality of Resetting Executive Stock Options, 57 J. FIN. ECON. 65 (2000)

197 See P. Jane Saly, Repricing Executive Stock Options in a Down Market, 16 J. ACCT. ECON. 325 (1994). 
resetting provides much more than downward price protection - options alone provide that - resetting lets executives "buy" on major market dips. Moreover, because the determinants of share prices are complex, executives can justify resetting when only a fraction of the decline in their firm's share price actually is attributable to a market correction.

In the second scenario executives hold indexed options. With indexed options the executives achieve only a portion of the incremental improvement in firm value above the sector or market average. The executives truly are insulated from broad market swings. Resetting becomes difficult, if not impossible, to justify, and market slides do not become opportunities for profit taking on the rebound. Thus, even if the executives receive more indexed options to reflect their reduced expected value, as they should, the loss of the resetting advantage leaves them worse off overall.

Optimal contracting explanations for resetting are further undermined by empirical analyses concerning the use of this device. Brenner, Sundaram, and Yermack find that resetting does not occur as a result of industry-wide shocks, as one would expect if the process were used to avoid penalizing executives for larger trends beyond their control.198 Rather, resetting is associated with poor firm-specific stock price performance, which might reward the management of poorly performing firms. ${ }^{199}$ Similarly, Chance, Kumar, and Todd find that re-pricing decisions are not driven by market or industry factors. ${ }^{200}$

\section{The Rent Extraction Explanation}

From the perspective of the outrage constraint, however, the resetting arrangement makes sense. Executives' enjoyment of large options gains when market prices advance can be justified easily to observers in this fashion: There was a contract; it provided incentives; all parties to the contract - shareholders and executives - enjoyed large gains; the firm sticks by its contracts. When the stock price drops, resetting can be justified based

on the need to retain and motivate executives as the firm moves forward. If the company is still nervous about public reaction, it can reduce the exercise

198 See Menachem Brenner et al., Altering the Terms of Executive Stock Options, 57 J. FIN. ECON. 103 (2000).

199 See id.

200 See Don M. Chance et al., The Repricing of Executive Stock Options, 57 J. FIN. ECON. 129 (2000). See also N.K. Chidambaran and Nagpurnanand R. Prabhala, Executive Stock Option Repricing, Internal Governance Mechanisms, and Manager Turnover, forthcoming JOURNAL OF FINANCIAL ECONOMICS (2001) (reporting that repricing firms are likely to have enjoyed rapid, above-industry growth rates and profitability two years before repricing, and a drop to below-industry growth rates and profitability the year of repricing). 
price somewhat, but leave it above market to show investors that the executives are not getting a free ride..$^{201}$

The practice of resetting also must be considered in light of the failure of companies to index options. As noted above, the combination of effects seems to enhance executive rent extraction. Executives appear to be much better off with regular options that may be reset than they would be with indexed options.

Finally, empirical data also support the rent extraction explanation. For example, Chance, Kumar, and Todd find that re-pricing is more likely among smaller firms with boards that are dominated by insiders and otherwise suffer from greater agency problems. ${ }^{202}$ And Callaghan, Saly, and Subramaniam report that executives release bad news shortly before the date on which the options are repriced and delay the release of good news until after that date in order to reduce the exercise price on the repriced options. ${ }^{203}$

\section{Executives' Broad Freedom to Unwind Incentives}

Companies claim that they use equity-based compensation as a means of aligning incentives and increasing executive shareholding. ${ }^{204}$ But firms take surprisingly few steps to prevent executives from unwinding the incentives provided by the grant of options and restricted stock. ${ }^{205}$

201 See Menachem Brenner et al., Altering the Terms of Executive Stock Options, 57 J. FIN. ECON. 103 (2000) (reporting that the strike price was reduced but left above market in about $20 \%$ of the resetting cases examined).

202 See Don M. Chance et al., The Repricing of Executive Stock Options, 57 J. FIN. ECON. 129 (2000).

203 See Sandra Renfro Callaghan, P. Jane Saly, and Chandra Subramaniam, The Timing of Option Repricing (working paper, 2000). See also David Yermack, Good Timing: CEO Stock Option Awards and Company News Announcements, 52 JOURNAL OF FINANCE 449 (1997)(reporting that managers manipulate news around option grants in order to lower the exercise price).

204 See Eli Ofek and David Yermack, Taking Stock: Does Equity-Based Compensation Increase Managers' Ownership?, 55 J. FIN. 1367 (1997) (noting that companies frequently cite a desire to boost executive share ownership in justifying equity-based compensation awards).

205 It is not unusual for a firm to use "trading windows" and "blackout periods" to restrict the times during the year that a manager can trade in the shares in order to reduce the possibility that it will be held liable for an insider trading violation. For example, many firms permit managers to trade only during the two or three-week period after quarterly earnings have been released. See Carl Bettis, J. Coles, and Michael L. Lemon, Corporate Policies Restricting Trading by Insiders, 57 J. FIN. ECON. 191 (2000). Such restrictions might impose liquidity costs on managers by sometimes forcing managers to delay a planned trade for several months. $C f$. 
Executives generally are not barred from hedging away equity exposure before these instruments vest, nor are they constrained in exercising the options and disposing of the stock acquired once vesting has occurred. The permissive attitude of firms in this respect presents an additional puzzle for the optimal contracting view.

All else being equal, executives generally prefer to have less of their personal wealth tied up in the stock and options of their firm rather than more. ${ }^{206}$ It should come as no surprise, then, that executives often sell shares when granted options or restricted stock, exercise options well before expiration, sell the stock acquired through option and restricted share programs, and look for ways of hedging their exposure when disposal is not possible.

Executives often utilize collars and equity swaps to lock in gains on their shareholdings following a stock price increase, reducing their incentive to boost the price further. ${ }^{207}$ When they receive options and restricted stock, executives take steps to decrease their exposure to the risk. In particular, executives often sell stock they already hold when the options (or restricted shares) are granted. ${ }^{208}$ Moreover, some executives hedge or seek advice on hedging the risks associated with restricted stock and option holdings through the use of derivative securities. ${ }^{209}$ At the moment, several

Darren T. Roulstone, The Relation Between Insider-Trading Restrictions and Executive Compensation (working paper, 2001) (finding that firms that restrict the timing of insiders' trades pay a $3-10 \%$ premium in total compensation). However, these restrictions do not limit the number of shares that can be sold or the type of transaction that can be entered into during the time trading is permitted. Thus, these trading restrictions cannot prevent managers from selling or hedging their equity positions.

206 As is widely recognized, executives tend to have a large proportion of their personal wealth as well as their human capital invested in their firms. The sale of shares (acquired through exercise of options or otherwise) permits diversification and supports current consumption.

207 See Carr Bettis et al, Insider Trading in Derivative Securities: An Empirical Examination of the Use of Zero-Cost Collars and Equity Swaps by Corporate Insiders (working paper, 1999).

208 See Eli Ofek and David Yermack, Taking Stock: Does Equity-Based Compensation Increase Managers' Ownership?, 55 J. FIN. 1367 (1997) (finding that managers who already owned shares in excess of the number of options (or restricted shares) granted sold approximately 680 shares for every 1000 options granted and 940 shares for every 1000 restricted shares granted).

209 See David M. Schizer, Executives and Hedging: The Fragile Legal Foundation of Incentive Compatibility, 100 COLUMBIA LAW REviEW 440 (2000). Cf. Paul U. Ali and Geof Stapledon, Having Your Options and Eating Them Too: Fences, Zero-Cost Collars and Executive Share Options, 18 COMPANY \& SEC. L. J. 277 (2000)(describing the use of hedging devices by managers as an "alarming development" that subverts the economic purpose of stock options). 
serendipitous features of the federal income tax code make it economically unattractive for most executives to hedge unvested options and (to a lesser extent) restricted stock through the derivatives market. ${ }^{210}$ But even modest changes in tax rates could eliminate this barrier to hedging options. ${ }^{211}$

Once the options vest, executives exercise options well before expiration despite the tax disincentive. ${ }^{212}$ A recent study examining ten-year options granted to the executives of forty large companies determined that the options were exercised after an average of 5.8 years. ${ }^{213}$ Moreover, despite the pressure that boards supposedly put on executives to increase their shareholdings, executives sell almost all of the shares that are acquired through option exercise, far in excess of the level of sales required to satisfy the taxes due. 214

Firms could make it more difficult for executives to unwind unilaterally the incentives provided by restricted stock and options. ${ }^{215}$ Generally, the only constraint faced by an executive who wishes to cash out restricted stock or options is the vesting period placed on the instrument. Until the instrument vests, the stock or option is forfeited if the executive leaves the firm, ${ }^{216}$ but companies take no steps to restrict executives from hedging away the equity risk exposure of unvested stock and options. Moreover, after the instrument vests, the executive is free to dispose of the

210 See David M. Schizer, Executives and Hedging: The Fragile Legal Foundation of Incentive Compatibility, 100 COLUMBIA LAW REVIEW 440 (2000).

211 Cf. Austan Goolsbee, What Happens When You Tax the Rich? Evidence from Executive Compensation, 108 JOURNAL OF POLITICAL ECONOMY 352 (2000) (finding that executives adjust option exercise patterns in response to changes in marginal tax rates).

212 See David M. Schizer, Executives and Hedging: The Fragile Legal Foundation of Incentive Compatibility, 100 Columbia Law Review 440, 468-472 (2000)(explaining that the deferral of taxes provides executives with a tax benefit from delaying the exercise of nonqualified stock options).

213 See Jennifer N. Carpenter, The Exercise and Valuation of Executive Stock Options, 48 J. FIN. ECON. 127, 139 (1998). See also Steven Huddart and Mark Lang, Employee Stock Options Exercises: An Empirical Analysis, 21 J. ACCT. ECON. 5, 20 (1996) (analyzing stock option exercise at eight diverse firms, some of which granted options to half or more of their employees, and reporting that among the seven publicly traded firms the average fraction of life that had elapsed at the time of option exercise ranged from .23 to .40).

214 See Eli Ofek and David Yermack, Taking Stock: Does Equity-Based Compensation Increase Managers' Ownership?, 55 J. FIN. 1367 (1997).

215 See David M. Schizer, Executives and Hedging: The Fragile Legal Foundation of Incentive Compatibility, 100 Columbia Law Review 440 (2000).

216 Some compensation plans, however, provide for accelerated vesting in the case of dismissal without cause or in the case of a takeover-related dismissal. Telephone interview with Michael Meissner; Squire, Sanders \& Dempsey, L.L.P. (Sept. 7, 2000). 
restricted stock or exercise the option and sell the underlying stock - even if he is expected to stay and does in fact stay with the company for a much longer period.

We would expect an optimal principal-agent contract to place more constraints on executives than we observe. If options are provided in order to create incentives for executives, it is important that the risk-bearing executive not be permitted to unwind the incentive without restriction. To be sure, there may be circumstances in which an executive's diversification and consumption needs would warrant permitting an executive to cash out. However, if options were granted to supply incentives, one would expect that these incentives would be protected by at least some explicit contractual constraints. The consumption and diversification arguments do not explain why executives are permitted to unwind incentives without any restriction whatsoever.

In addition to the standard vesting term, which provides an incentive for an executive to remain with the company, we would expect an optimal incentive contract to include additional specific limitations on the exercise of some or all options and/or on the sale of the shares underlying these options, perhaps with a process enabling early disposition in the case of hardship. ${ }^{217}$ We also would expect to observe contractual restrictions on hedging restricted stock or option positions through the use of derivatives or equity swaps.

For example, an option could be granted that vests after a certain number of years but is not exercisable until a later point in time. Such an arrangement would provide an executive with certainty of ownership after the first period, but would ensure continued incentive generation over the second period. If an executive were to leave the company after the vesting date but before the first exercise date, the company might commit to repurchasing the option based on some discount to the prevailing market price so as not to encourage early exit. In any event, there is no clear reason that vesting and first exercise must correspond, and yet this is the universal practice.

217 Given the apparent difficulty of achieving the optimal level of executive equityholding, it seems unwise to provide executives unfettered discretion over this variable. Too little shareholding apparently produces insufficient incentives and reduces shareholder value, while too much shareholding has the same end result, presumably because of executive entrenchment. See John J. McConnell and Henri Servaes, Additional Evidence on Equity Ownership and Corporate Value, 27 J. FIN. ECON 595 (1990); Randall Morck et al., Management Ownership and Market Valuation: An Empirical Analysis, 20 J. FIN. ECON. 293 (1988). But see Charles P. Himmelberg et al., Understanding the Determinants of Managerial Ownership and the Link Between Ownership and Performance, 53 J. FIN. ECON. 353 (1998) (reporting that they are unable to conclude econometrically that managerial ownership affects firm performance). 
To be sure, the executives might have liquidity needs. But there are a number of ways that such liquidity needs could be dealt with. For example, one could make executives get permission to sell from the compensation committee, which could approve the unwinding upon the showing of liquidity needs. Or the executives could be permitted to sell their shares slowly over time. It is unlikely that the only solution to executives' liquidity needs is to give them unlimited ability to unwind unrestricted shares and vested options.

The other puzzling aspect of managers' ability to unwind is that they have the freedom to choose when to sell so that they can sell when they think the price is high. ${ }^{218}$ One could, instead, require executives to sell shares back to the corporation at the average price of the stock over the preceding year or two.

Once again, we believe that the corporate behaviors that we have discussed in this section are more compatible with the rent extraction model of executive compensation than with the optimal contracting model. Under the rent extraction view companies fail to restrict executives from unwinding incentives because stock-based compensation largely is about providing executives with noncontroversial compensation. As we have noted above, compensation paid through dilution may be less visible than stock pricerelated cash compensation, which may explain why companies pay executives in stock but remain nonchalant about subsequent sales. Options also provide incentives, and vesting requirements help ensure that the incentives persist for some time, ${ }^{219}$ but much of this evidence seems more consistent with maximizing executive rent extraction than with optimizing incentives.

\section{E. Reload Options}

The increasingly common practice of granting new, or "reload," options to executives who exercise options by surrendering stock is yet another twist to conventional options plans that we think is better explained

218 To be sure, executives might be constrained in their ability to sell at any particular time by firm-imposed trading windows or the securities laws. However, even within these constraints, executives are able to trade on some forms of inside information.

${ }^{219}$ However, this is true only because tax rules discourage executives from hedging options with derivatives. See David M. Schizer, Executives and Hedging: The Fragile Legal Foundation of Incentive Compatibility, 100 Columbia Law Review 440 (2000). 
by the rent extraction model than by the optimal contracting model. ${ }^{220}$ Basic reload options work as follows: The holder of an option with a reload provision who exercises that option before expiration and pays the exercise price with stock that he already owns receives the underlying shares optioned plus a new option for each share tendered in exercising the options. The new reload options carry the same expiration date as the original options but the exercise price is set at market. For example, a CEO who held ten reloadable options with a $\$ 20$ strike price would surrender five shares of stock to exercise the options if the market price at exercise stood at $\$ 40 /$ share. He would receive the ten shares optioned plus five new reload options with a $\$ 40$ strike price. ${ }^{221}$

Options with a reload provision are worth substantially more to the holder than are conventional options. By exercising the first generation options after a price spike, the recipient locks in a portion of the gain against a subsequent share price decline, but the recipient loses none of the upside potential, which is preserved fully by the reload options.222 The incremental value of the reload feature depends on the volatility of the firm's stock price and other factors, but, examining one executive at one firm by way of example, Saly, Jagannathan \& Huddart estimated that basic reload options in that case were worth about $15 \%$ more than conventional options. 223

As with the failure to index options, the grant of reloads furthers the ability of executives to capture large benefits without enhancing shareholder value. Specifically, reload options enable executives to profit from share price volatility even if long-term share performance is flat. Thus, reload options provide value to executives without a clear incentive benefit. 224

220 Reingold reports that reload provisions were included in $17 \%$ of new stock option plans adopted in 1997. See Jennifer Reingold, Nice Option if You Can Get It, BUS. WEEK, May 4, 1998, at 111.

221 There are several variations on the reload theme. Some plans provide for multiple reloads, in other words, the new options issued on exercise also are reloadable. Some reload plans provide additional reload options to replace shares that would have to be sold to pay the tax that is due on exercise. Finally, under some reload plans, the reload options issued on exercise carry a new or extended term. However, recently promulgated FASB Interpretation 44 may impose unfavorable accounting requirements on multiple reload and other variants from the standard reload arrangement. See FASB Interpretation 44 (Mar. 2000).

222 Hemmer and colleagues demonstrate that it is optimal for the holder of a multiple reload option to exercise whenever the stock price exceeds any previous high price. See Thomas Hemmer et al., Optimal Exercise and the Cost of Granting Employee Stock Options with a Reload Provision, J. ACCT. RESEARCH 231 (1998).

223 See P. Jane Saly et al., Valuing the Reload Feature of Executive Stock Options, 12 ACCT. HORIZONS 219 (1999).

224 If a manager could reload repeatedly, the optimal strategy for the manager would be to exercise his options whenever there is even a small rise over the exercise price, and then reload. 
The addition of a reload feature cannot be readily explained within the optimal contracting model. Consider first an executive who would hold conventional options until expiration. The reload feature simply allows this executive to exercise the first generation options to take advantage of a price spike along the way. If the resultant shares are sold, there is a reduction in incentives, and the executive receives a windfall versus a conventional option plan.

Now consider an executive who would exercise conventional options before expiration in order to reduce risk. In this case, the reload options provide a continuing, yet diminished, incentive after the first generation options are exercised and the underlying shares are sold. However, the executive could have exercised a portion of his conventional options and achieved the same reduction in exposure. Even if there is a risk bearing argument for reloads, moreover, that argument depends on options comprising a portion of the reservation wage. If, as we have suggested, option compensation often exceeds the reservation wage in order to provide incentives, it would be more efficient for firms to prohibit early exercise than to issue reloadable options.

Nonetheless, despite the greater cost, proponents argue that the reload feature encourages executives to exercise options earlier and to hold more shares.225 The reload feature does promote earlier exercise, but if the executives sell the shares they receive on exercise, as is generally the case, 226 the reloads do not result in executives holding more shares unless there are additional constraints on the reload program. Some reload plans place minimum holding times on the stock surrendered on exercise or on the stock

225 See Christopher Gay, Hard to Lose: Options Promote Stock Ownership among Executives: But Critics Say They're A Lot More Costly than Shareholders Realize, WALL ST. J., Apr. 8, 1999 at R6; Jennifer Reingold, Nice Option If You Can Get It, BUS. WEEK, May 4, 1998, at 111; Thomas Hemmer et al., Reload Employee Stock Option Plans: Incentive Alignment or Rent Extraction 15 JOURNAL OF ACCOUNTING, AUDITING, AND FINANCE 393 (2000).

226 See Eli Ofek and David Yermack, Taking Stock: Does Equity-Based Compensation Increase Managers' Ownership?, 55 J. FIN. 1367 (1997) (examining data from the S\&P 1500 over the 1993-1995 period and finding that executives with relatively low stock holdings retain about $30 \%$ of the shares received on exercise of options, while relatively high ownership executives sold all shares). Although a basic reload plan is unlikely to increase executives' total exposure to share price, substituting at-the-money options for far in-the-money options may result in some improvement in incentives. See Robert A. Lambert et al., Portfolio Considerations in Valuing Executive Compensation, 29 J. ACCT. RESEARCH 129 (1991) (demonstrating that options that are highly likely to end up in-the-money can increase rather than decrease a manager's aversion to risk). 
received through exercise.227 However, firms could require executives to hold shares received through the exercise of options without introducing the reload complication. If the goal is to increase executive share ownership, as we discussed above, there are better and more direct ways to proceed. 228

As in the case of resetting, however, the reload feature is quite consistent with the rent extraction view of executive compensation. The reload feature makes the options more valuable for the executives, but it does so in a way that is complex and hard to evaluate. ${ }^{229}$ Despite their added cost, reloads can be justified plausibly to investors. And even better, reloads can be tweaked to provide even more value with little or no investor reaction. We have already seen that options with the basic reload feature are more valuable to their recipients, and we have suggested that their justification - increasing executive stock ownership - is facially plausible, but that the benefit is illusory unless the executives are required to hold shares for some period prior to or following option exercise - constraints that have little or nothing to do with reloads per se. We will now turn to the variations in reloads that add even more value.

An executive who exercises nonqualified stock options owes ordinary income tax on the gain. Many firms with reload programs issue additional reload options to cover the shares that must be set aside to pay the

227 See Thomas Hemmer et al., Reload Employee Stock Option Plans: Incentive Alignment or Rent Extraction 15 JOURNAL OF ACCOUNTING, AUDITING, AND FINANCE 393 (2000). The authors find a significant increase in CEO shareholding following the adoption of reload provisions.

228 In a recent paper, Hemmer, Matsunaga, and Shevlin offer empirical evidence that provides some support for an optimal contracting view of reload provisions. The authors find a statistically significant negative correlation between a group of variables reflecting CEO power and the incidence of reload provisions. They also find a positive correlation between board strength and reload incidence, although the correlation is not statistically significant. If reload provisions facilitate rent extraction, the authors posit, one would expect to observe greater incidence in firms in which CEO's have relatively greater power to extract rents. See Thomas Hemmer et al., Reload Employee Stock Option Plans: Incentive Alignment or Rent Extraction, 15 JOURNAL OF ACCOUNTING, AUDITING, AND FINANCE 393-423 (2000). The question remains, however, why firms should resort to the use of reload provisions to encourage executives to hold onto more shares when more direct approaches are available.

${ }^{229}$ It is clear that an option with a reload feature is more valuable than a plain vanilla option, but in a steadily rising market the reload feature affects only the timing of the realization of the gains. Those who focus on this facet of the market only will miss the true value of the reload provision. See Christopher Gay, Hard to Lose: Options Promote Stock Ownership Among Executives: But Critics Say They're A Lot More Costly Than Shareholders Realize, WALL ST. J., Apr. 8, 1999 at R6. 
executive's taxes. 230 This practice is justified as necessary to maintain the executive's total share price exposure. ${ }^{231}$ This sounds plausible at first blush, but in fact the tax reload provision, as it is known, is the equivalent of making a larger conventional option grant in the first place. If, as we have argued, the relative size of initial option grants is benchmarked against the size of grants made by comparable firms and is a salient figure for investors, introducing tax reloads serves to circumvent the cap on the size of initial grants. And, of course, the larger effective grant is more valuable to the executive and more costly for the shareholders. ${ }^{232}$

Moreover, one may ask, what is so special about the tax that is due on the exercise of options? Most executives own a fair number of shares of company stock and owe taxes each year on their salary, bonus, options exercised, and restricted stock that becomes unrestricted. One could argue as plausibly that the company should issue options to replace hypothetical shares sales made by an executive to cover the taxes due on any of these sources of income. In the absence of real constraints on overall executive shareholding, it is pointless if not misleading to focus on maintaining the number of shares and options that flow directly from the firm's option program.

\section{F. Differences Between Executives with More and Less Power}

The rent extraction view focuses upon the connection between managerial power and the rents managers can extract. In all companies with dispersed shareholders and no controlling shareholder, executives will have

230 See id. (reporting that 21 of 40 reload firms surveyed issue additional options to replace shares set aside to pay taxes on option exercise).

231 See id.

232 Saly and colleagues estimated that, with the tax reload feature, the reload options they studied were worth $24 \%$ more than conventional options. Without the tax reload feature these reload options would have been worth $15 \%$ more than conventional options. See P. Jane Saly et al., Valuing the Reload Feature of Executive Stock Options, 12 ACCT. HORIZONS 219 (1999). A few companies deviate from the standard reload design in other ways. Some issue a new option for every option exercised, rather than for each share surrendered in exercising the options. See Christopher Gay, Hard to Lose: Options Promote Stock Ownership among Executives: But Critics Say They're A Lot More Costly Than Shareholders Realize, WALL ST. J., Apr. 8, 1999 at R6 (reporting that 3 of 40 reload firms surveyed used this procedure). Others extend or restart the term of reload options issued. See Christopher Gay, Hard to Lose: Options Promote Stock Ownership Among Executives: But Critics Say They're A Lot More Costly Than Shareholders Realize, WALL ST. J., Apr. 8, 1999 at R6. Both practices add value for executives, and one can imagine without help from us the weak but perhaps vaguely plausible justifications that might be offered in support of these variants. 
power and will likely be able to extract some rent. Management power, however, is not uniform in all companies with dispersed shareholding. Managers will have more or less power depending upon the presence of effective takeover impediments, the structure of the board, the presence of large shareholders (even if they are not controlling shareholders), and the fraction of shares held by institutional investors. All else being equal, the rent extraction view predicts that managers will extract more rent in situations and structures in which they have more power.

Indeed, there is significant evidence suggesting that in situations in which executives have more power, they are able to extract more rent. First, there is evidence that CEO's of firms that adopt anti-takeover provisions get higher salaries, receive more options, and are more likely to have a golden parachute arrangement. ${ }^{233}$ The mean level of above-market compensation then increases significantly after the provisions are adopted - that is, after the CEO has become less vulnerable to a hostile takeover. 234

In addition, there is evidence that executive compensation is higher in circumstances in which a CEO is especially powerful vis-à-vis the board. Core, Holthausen, and Larcker find that CEO compensation is higher when the board is larger, when more of the outside directors have been appointed by the CEO, when the outside directors are older, and when outsiders serve on five or more boards. ${ }^{235}$ Rather than imposing discipline on the pay

233 Kenneth A. Borokhovich, Kelly R. Brunarski, and Robert Parrino, CEO Contracting and Anti-Takeover Amendments, 52 JOURNAL OF FINANCE 1495 (1997).

234 See Kenneth A. Borokhovich, Kelly R. Brunarski, and Robert Parrino, CEO Contracting and Anti-Takeover Amendments, 52 JOURNAL OF FINANCE 1495 (1997). Managers who have become less vulnerable to a hostile takeover take advantage of their power in other ways as well. For example, CEO's of firms incorporated in states that adopt anti-takeover statutes reduce their use of debt, in order to reduce the risk of financial distress and constraints on their use of the firms' cash, even though the debt is likely to have provided useful tax and agency benefits. Gerald T. Garvey and Gordon Hanka, Capital Structure and Corporate Control: The Effect of Antitakeover Statutes on Firm Leverage, 54 JOURNAL OF FINANCE 519 (1999).

235 See John E. Core et al., Corporate Governance, Chief Executive Officer compensation, and Firm Performance, 51 J. FIN. ECON. 371 (1999). Yermack confirms that larger boards produce weaker CEO pay incentives. See David Yermack, Higher Market Valuation of Companies with a Small Board of Directors, 40 J. FIN. ECON. 185 (1996). Cf. Robert Evans and John Evans, The Influence of Non-Executive Director Control and Rewards on CEO Remuneration: Australian Evidence (working paper, 2000) (finding that CEO compensation in Australia is decreasing in the amount of equity held by outside directors.) CEO pay also increases when a board contains interlocking directors. See Kevin Hallock, Reciprocally Interlocking Boards of Directors and Executive Compensation, 32 J. FIN. \& QUANTITATIVE ANALYSIS 331 (1997). This might not be as rare as one would imagine: in approximately 1 out of 12 firms the board is current CEO-interlocked: the CEO of the firm (Firm A) sits on the board of another company (Firm B), and the CEO of Firm B sits on the board of Firm A. See 
process, an outsider-heavy board may simply serve to legitimize the CEO's decision making and increase his ability to extract rent. ${ }^{236}$ There also is evidence that the concentration of institutional investors matters. In a study of S\&P firms from 1991 through 1997, Hartzell and Starks find that more concentrated institutional ownership is associated with reduced executive compensation. They also find that a larger institutional presence results in more performance sensitive compensation. ${ }^{237}$ This study suggests that the presence of institutions serves to reduce the power of management to extract rent through compensation.

Moreover, there is evidence that the presence of large shareholders is significant. Even when such shareholders do not have a controlling or dominant position, their monitoring may reduce the extraction of rent. Richard Cyert and his colleagues found a negative relationship between the equity ownership of the largest shareholder and the amount of CEO compensation. ${ }^{238}$ In an analysis of manufacturing firms, Tosi and GomezMejia determined that CEO incentive alignment is superior and that the CEO exercises less influence over setting his own compensation when the company has a five-percent external shareholder. ${ }^{239}$

Kevin Hallock, Dual Agency: Corporate Boards with Reciprocally Interlocking Relationships, in EXECUTIVE COMPENSATION AND SHAREHOLDER VALUE: THEORY AND EVIDENCE (Jennifer Carpenter and David Yermack, eds.) (Kluwer Academic Publishers: London) (1999) 55, 58 (reporting that 8\% of a sample of 773 large publicly-traded firms had CEO-interlocked boards and $12 \%$ had employeeinterlocked boards). See also Eliezer M. Fich and Lawrence J. White, Why Do CEO's Reciprocally on Each Other's Boards? (working paper, 2001) (examining factors that make reciprocal CEO board membership more likely).

236 See Brian G. M. Main et al., The CEO, the Board of Directors, and Executive Compensation: Economic and Psychological Perspectives, 11 INDUS. \& CORP. CHANGE 293 (1995). Cyert, Kang, Kumar, and Shah report that CEO pay is negatively related to the share ownership of the board of directors and positively related to the CEO's share ownership and tenure and is higher if the CEO is the chairman of the board. They also find that CEO pay is positively related to the percentage of outsiders on the board. They surmise that many of the outside directors are hand-picked friends of the CEO. See Richard Cyert et al., Corporate Governance, Ownership Structure, and CEO Compensation (working paper, 1997).

237 See Jay C. Hartzell and Laura T. Starks, Institutional Investors and Executive Compensation (working paper, 2000).

238 See Richard Cyert et al., Corporate Governance, Ownership Structure, and CEO Compensation (working paper, 1997).

239 See Henry L. Tosi Jr. and Luis R. Gomez-Mejia, The Decoupling of CEO Pay and Performance: An Agency Theory Perspective, 34 ADMINISTRATIVE SCI. Q. 169 (1989). See also Henry L. Tosi and Luis R. Gomez-Mejia, CEO Compensation Monitoring and Firm Performance, 37 ACADEMY MANAGEMENT J. 1002 (1994) (finding the relationship between monitoring and performance to be stronger in firms that lack a $5 \%$ shareholder than in firms that have a 5\% shareholder). Similarly, Benz, Kucher, and 
In three recent creative empirical studies, Bertrand and Mullainathan than have presented findings that indicate that the absence of any shareholders with more than five percent of the shares leads to increased extraction of rent. One study examined differences between companies with and without such shareholders in terms of how executive compensation programs were affected by the passage of anti-takeover legislation. ${ }^{240}$ The authors found that CEO pay increased in firms that lacked a large external shareholder following the reduction in the takeover threat, and that only firms with a large shareholder responded to the reduced takeover threat by increasing pay-for-performance sensitivity. ${ }^{241}$

In another paper, Bertrand and Mullainathan examined differences between companies with and without a large shareholder in terms of the extent to which CEO's were rewarded for changes in company performance that were outside of their control, i.e., for luck.242 The study found that CEO's in firms that lacked large external shareholders tended to receive more "luck-based" pay. Furthermore, this study also found that CEO's in firms that lacked large shareholders had their cash compensation reduced less when their options-based compensation increased. ${ }^{243}$

A third study by Bertrand and Mullainathan tested differences between companies with and without a five-percent shareholder in terms of how the performance sensitivity of compensation relates to the volatility of the company's stock price. ${ }^{244}$ Under an optimal contracting view, payperformance sensitivity should decrease with increasing variance. However, the study found the presence of such a relationship only for companies that had a five-percent external shareholder.

Interestingly, the financial economists that conducted the above studies, unlike most academics working in this area, came to the view that some appropriation of wealth might be taking place in those situations in which managers are especially powerful. Bertrand and Mullainathan, for example, concluded that some "skimming" takes place in companies without a five-percent shareholder. ${ }^{245}$ The above researchers, however, have

Stutzer find that a higher concentration of shareholders results in a significantly reduced amount of options granted to top S\&P 500 executives. See Matthias Benz et al., Stock Options: The Managers' Blessing; Institutional Restrictions and Executive Compensation (working paper, 2000).

240 See Marianne Bertrand and Sendhil Mullainathan, Executive Compensation and Incentives: The Impact of Takeover Legislation (working paper, 1998).

241 See id.

242 See Marianne Bertrand and Sendhil Mullainathan, Do CEO's Set Their Own

Pay? The Ones Without Principals Do (working paper, 2000).

243 See id.

244 See Marianne Bertrand and Sendhil Mullainathan, Agents With and Without Principals, 90 AMER. ECON. ASSOC. 203 (2000).

245 See id. 
accepted the presence of rent extraction as a phenomenon applying only to situations in which managers are relatively more powerful rather than applying more generally.

In our view, once the connection between power and rent is recognized, there is reason to believe that rent extraction might take place to some extent in all companies without a controlling or dominant shareholder. To be sure, managers can be expected to have relatively less power, and thus to be able to extract less rent, in circumstances in which a large external shareholder is present or more shares are in the hands of institutions. Even in such circumstances, however, managers still have considerable power, as we have explained, and can thus be expected to extract rent. ${ }^{246}$ Indeed, the evidence that we have described in the preceding sections of Part IV, which applies also to institution- or large shareholder-influenced companies, indicates that rent extraction might well take place, even if to a reduced extent, in such companies.

\section{G. Differences between U.S. and Non-U.S. Companies}

U.S. CEO's are paid considerably more than their non-U.S. counterparts, ${ }^{247}$ but lower-level U.S. executives do not receive premium pay. ${ }^{248}$ U.S. CEO's receive both more total compensation and more option or equity-based pay. ${ }^{249}$ Even ignoring incentive pay, however, U.S. CEO's receive greater compensation than their non-U.S. counterparts. ${ }^{250}$ U.S. human resources directors, by comparison, receive no more compensation and no more long-term incentive compensation than their international

246 Consider cases in which a five- or ten-percent external shareholder is present. Given the power that managers have to issue poison pills and to control the proxy machinery, such a shareholder might have influence but usually not anything that is close to controlling power. Thus, executives in such cases are likely to have still a great deal of power.

247 See John M. Abowd and Michael L. Bognanno, International Differences in Executive and Managerial Compensation, in DIFFERENCES AND CHANGES IN WAGE STRUCTURES 70-72 (R. Freeman and L. Katz, eds., 1995); Murphy, supra note 3.

248 See John M. Abowd and Michael L. Bognanno, International Differences in Executive and Managerial Compensation, in DIFFERENCES AND CHANGES IN WAGE STRUCTURES 72-73 (R. Freeman and L. Katz, eds., 1995).

249 See John M. Abowd and Michael L. Bognanno, International Differences in Executive and Managerial Compensation, in DIFFERENCES AND CHANGES IN WAGE STRUCTURES 70-72 (R. Freeman and L. Katz, eds., 1995); Murphy, supra note 3.

250 See Mark J. Lowenstein, The Conundrum of Executive Compensation, 35 WAKE FOREST L. REV. 1 (2000). 
counterparts. ${ }^{251}$ The U.S./international CEO pay gap provides yet another puzzle for students of executive compensation to explain. ${ }^{252}$

Can the optimal contracting view provide a persuasive explanation for this pattern? First, it might be argued that U.S. CEO's are simply more important or more scarce. The skills of the CEO would be more important in the U.S. if our corporate culture is more focused on the top than others. Undoubtedly the CEO is the major factor in the success of many U.S. companies, but surely CEO's are very important in many foreign countries. Moreover, although U.S. firms employ a particularly large number of CEO's, they employ an even larger number of junior executives. It is unclear why qualified CEO's would be relatively more scarce. ${ }^{253}$

CEO's also could be argued to be more important in the U.S. because the competitive markets in the U.S. are more "demanding," and this makes a CEO's skills more important for the company's performance. In economies with much government regulation and intervention, however, a company's performance might also depend critically on the skills of the CEO (but in this case on different skills) in dealing with political and regulatory constraints.

Second, it might be that the tournament model of executive compensation is more applicable in the U.S. than it is in other countries. According to this theory of compensation, junior executives accept lower pay in their present jobs in exchange for the chance of winning the tournament, becoming CEO, and capturing the big prize. ${ }^{254}$ It is possible that this extremely competitive, survival-of-the-fittest model simply works better in

251 See John M. Abowd and Michael L. Bognanno, International Differences in Executive and Managerial Compensation, in DIFFERENCES AND CHANGES IN WAGE STRUCTURES 72-73 (R. Freeman and L. Katz, eds., 1995).

252 See Murphy, supra note 3 for a thorough review of the puzzle posed by cross-country differences in CEO compensation.

253 Rosen argues that in market equilibrium the most talented executives will hold the top positions in the largest companies where their marginal productivity will be most greatly magnified, and that scarcity rents will pertain. See Sherwin Rosen, Authority, Control, and the Distribution of Earnings, 13 BELL. J. ECON. 311 (1982); Sherwin Rosen, Contracts and the Market for Executives in 1 THE ECONOMICS OF EXECUTIVE COMPENSATION 182 (Kevin J. Hallock and Kevin J. Murphy, eds.) (1992). This ability-matching theory of compensation finds further support in evidence that CEO's of firms operating multiple lines of business are paid more than CEO's of similarly sized nondiversified firms. See Nancy Rose and Andrea Shepard, Firm Diversification and CEO Compensation: Managerial Ability or Executive Entrenchment? 28 RAND J. ECON. 489 (1994) (arguing that the weight of the evidence is more consistent with an ability matching theory than with entrenchment). It is not clear, however, why U.S. businesses would be more susceptible to scarcity rents than nonU.S. firms.

254 See Edward P. Lazear and Sherwin Rosen, Rank-Order Tournaments as Optimum Labor Contracts, 89 J. POL. ECON. 841 (1981). 
our highly laissez faire corporate culture than it does abroad. There are theoretical problems with the tournament theory, ${ }^{255}$ however, and no real evidence that it applies to executive pay.

Third, it might be argued that U.S. firms are at the front of the learning curve when it comes to CEO pay. It has been suggested that other countries have not caught up to the U.S. with regard to stock-based compensation. ${ }^{256}$ However, the typical CEO in over half of the foreign countries surveyed by Towers Perrin in 1997 received options or other longterm performance units; they simply received less. ${ }^{257}$ Moreover, the learning curve hypothesis fails to explain why junior executives in the U.S are paid comparably with their non-U.S. peers, but U.S. CEO's are not.

While the pattern of cross-country differences is difficult to explain from the optimal contracting view, the rent extraction view can provide a persuasive account of it. As we have discussed, rent extraction depends on the power held by the managers. In the U.S., managers have considerable power, especially, as we have seen, when there is no large shareholder to provide discipline. The managers use this power to extract rent through enhanced executive compensation. For most U.S. CEO's, compensation is the only mechanism for extracting rent. Insider trading opportunities are limited, and professional U.S. CEO's rarely have other business interests that can be used to extract rent through favorable contractual arrangements. Executive compensation generally will be the only significant means of extracting monetary rent.

In other countries, the incidence of companies with dispersed ownership is much smaller, and companies with controlling shareholders are much more prevalent. ${ }^{258}$ In companies with controlling shareholders, there are two possibilities. If the $\mathrm{CEO}$ is not part of the controlling group or family, the controlling shareholder has an incentive to prevent excessive compensation. Alternatively, the $\mathrm{CEO}$ is a member of the controlling group or family. Typically, the controlling group or family will control other significant assets. In such a case, there often will be more important avenues

255 Unlike contracts, tournaments may provide poor incentives when it is apparent that one player is likely to win and others likely to lose the competition (due to differences in skills or other qualities). Tournament compensation structures may be unstable if some firms pay by contract. Tournaments may encourage collusion or sabotage. Finally, when outputs are multidimensional, determining the winner of the tournament may be difficult. See Ronald A. Dye, The Trouble with Tournaments, 22 ECON. INQUIRY 147 (1984).

256 See John M. Abowd and Michael L. Bognanno, International Differences in Executive and Managerial Compensation, in DIFFERENCES AND CHANGES IN WAGE STRUCTURES 67 (R. Freeman and L. Katz, eds., 1995).

257 See Murphy, supra note 3.

258 See Rafael LaPorta, Florencio Lopez-de-Silanes, and Andrei Shleifer, Corporate Ownership Around the World, 54 JOURNAL OF FINANCE 417 (1999). 
of extracting rent - through self-dealing and the taking of business opportunities. ${ }^{259}$ In this case, limiting executive compensation might be an effective means of camouflaging the overall rent that is being extracted. Limiting compensation would create the impression that the controlling shareholder is being loyal to minority shareholders, and compensation is not the big source of rent in this situation anyway.

In sum, in other countries the CEO either has less power to extract rent (if the CEO is not part of the controlling family/entity) or the CEO generally has other avenues to extract rent (if the CEO is affiliated with the controller). In contrast, in U.S. companies with dispersed shareholders, executives have significant power, which they use to extract rent through the only means available to them - maximizing their own compensation.

The rent extraction explanation is consistent with the observation that the cross-country difference in pay is concentrated at the top, while lower level U.S. executives do not receive excessive pay. We have argued that at times power will be concentrated in the hands of the CEO, and at times in the hands of the top management team. This would suggest that at times the pay differential will be observed only at the level of the CEO, and at times the differential would be enjoyed by other top executives. Thus, it is not surprising that human resource directors and other lower-level executives who do not have a significant share of corporate power would not enjoy greater compensation in comparison with their non-U.S. peers. ${ }^{260}$

The rent extraction analysis that we have put forward here also is consistent with our explanation of the differences in compensation practices observed between U.S. companies that do and do not have large shareholders. Whether or not they control the firm, large shareholders have an incentive and some ability to constrain managerial rent extraction through excessive executive compensation.

\section{CONCLUSION}

This paper has examined two alternative views of executive compensation: an optimal contracting view, which thus far has dominated

259 See Lucian A. Bebchuk et al., Stock Pyramids, Cross-Ownership, and Dual Class Equity: The Creation and Agency Costs of Separating Control From Cash Flow Rights, in CONCENTRATED CORPORATE OWNERSHIP (R. Morck, ed.) (2000). It would be an interesting study to compare the compensation of executives who are and who are not members of controlling stockholder families and test the prediction that the latter would receive less compensation.

260 Another interesting study would compare international pay difference between CEO's, COO's, CFO's, and other very senior executives who might realistically share power with a CEO. 
academic research on the subject, and an alternative rent extraction view. Whereas the former view regards executive compensation as an instrument for combating the agency problem between managers and dispersed shareholders, the latter view regards such compensation as a product of the agency problem.

Analyzing the processes that set executive compensation, we have identified reasons to believe that their outcomes might deviate significantly from the optimal contracting model. Whatever the appearances, executive compensation generally is not the product of arms' length bargaining, but is the result of a process that executives can substantially influence. Moreover, although executive compensation is set against a background of market forces, these forces are hardly strong and precise enough to compel optimal contracting outcomes for compensation arrangements. As a result, executives can use their power to extract rents. The extraction of rent occurs against a background of certain constraints, and this provides incentives for structuring compensation arrangements in a way that camouflages the presence and extent of rent extraction.

Analyzing the large body of empirical evidence on executive compensation, we have concluded that the evidence supports the view that rent extraction plays a significant role in the process. Some broad features of the executive compensation landscape are consistent with both views. A number of significant features and patterns of executive compensation, however, can be better explained by rent extraction. Indeed, various puzzles that have long occupied researchers operating under the optimal contracting view can be well explained by the rent extraction model.

The role that rent extraction plays in executive compensation has implications for the study, practice, and regulation of corporate governance. For these implications to receive the attention they deserve, the role of rent extraction needs to be recognized and appreciated. We hope that this paper will contribute to such recognition and that it will provide a useful framework for subsequent study of the problem of rent extraction in executive compensation. 


\section{REFERENCES}

Abowd, John M. and David S. Kaplan, Executive Compensation: Six Questions that Need Answering, 13 Journal OF ECONOMIC PERSPECTIVES 145-168 (1999).

Abowd, John M. and Michael L. Bognanno, International Differences in Executive and Managerial Compensation, in DifFERENCES AND CHANGES IN WAGE STRUCTURES 67-103 (NBER Press: Chicago) (R. Freeman and L. Katz, eds.) (1995).

Acharya, Viral V., Kose John, and Rangarajan K. Sundaram, On the Optimality of Resetting Executive Stock Options, 57 JOURNAL OF FinANCIAL ECONOMICS 65-101 (2000).

Aggarwal, Rajesh K. and Andrew A. Samwick, Executive Compensation, Relative Performance Evaluation, and Strategic Competition: Theory and Evidence, 54 JOURNAL OF FINANCE 1999-2043 (1999).

Aggarwal, Rajesh K. and Andrew A. Samwick, The Other Side of The Tradeoff: The Impact of Risk on Executive Compensation, 107 JOURNAL OF POLITICAL ECONOMY 65-105 (1999).

Aggarwal, Rajesh K. and Andrew A. Samwick, Performance Incentives Within Firms: The Effect of Managerial Responsibility, NBER Working Paper 7334 (1999).

Agrawal, Anup and Gershon N. Mandelker, Managerial Incentives and Corporate Investment and Financing Decisions, 42 JOURNAL OF FINANCE 823-837 (1987).

Agrawal, Anup and Ralph A. Walkling, Executive Careers and Compensation Surrounding Takeover Bids, 49 JOURNAL OF FINANCE 985-1014 (1994).

Ali, Paul U. and Geof Stapledon, Having Your Options and Eating Them Too: Fences, Zero-Cost Collars and Executive Share Options, 18 COMPANY AND SECURITIES LAW JOURNAL 277-282 (2000).

Anderson, Ronald C. and John M. Bizjak, An Empirical Examination of the Role of the CEO and the Compensation Committee in Structuring Executive Pay, Working Paper, American University, Washington and Lee University, and Portland State University (2000).

Antle, Rick and Abbie Smith, An Empirical Investigation of the Relative Performance Evaluation of Corporate Executives, 24 JOURNAL OF ACCOUNTING RESEARCH 1-39 (1986). 
Baker, George P., Incentive Contracts and Performance Measurement, 100 JouRnAL OF POLITICAL ECONOMY 598-614 (1992).

Baker, George P. and Brian J. Hall, CEO Incentives and Firm Size, NBER Working Paper 6868 (1998).

Baker, George P., Michael C. Jensen, and Kevin J. Murphy, Compensation and Incentives: Practice vs. Theory, 43 Journal OF FINANCE 593-616 (1988).

Baker, Malcolm and Paul A. Gompers, An Analysis of Executive Compensation, Ownership, and Control in Closely Held Firms, Working Paper, Harvard Business School (1999).

Bebchuk, Lucian A., Federalism and the Corporation: The Desirable Limits on State Competition in Corporate Law, 105 HARVARD LAW REVIEW 1435-1510 (1992).

Bebchuk, Lucian A., Limiting Contractual Freedom in Corporate Law: The Desirable Constraints on Charter Amendments, 102 HARVARD LAW REVIEW 1820-1860 (1989).

Bebchuk, Lucian and Christine Jolls, Managerial Value Diversion and Shareholder Wealth, 15 JOURNAL OF LAW, ECONOMICS, AND ORGANIZATION 487-502 (1999).

Bebchuk, Lucian A., and Marcel Kahan, A Framework for Analyzing Legal Policy Towards Proxy Contests, 78 CALIFORNIA LAW REviEW 1071-1135 (1990).

Bebchuk, Lucian A., Reinier Kraakman and George Triantis, Stock Pyamids, Crossownership, and Dual Class Equity, in CONCENTRATED CORPORATE OWNERSHIP 295-315 (R. Morck, ed.) (2000).

Bebchuk, Lucian A., and Mark J. Roe, A Theory of Path Dependence in Corporate Ownership and Governance 52 STANFORD LAW REVIEW 127-170 (1999).

Belliveau, Maura A., Charles A. O'Reilly III, and James B. Wade, Social Capital at the Top: The Effects of Social Similarity and Status on CEO Compensation, 39 ACADEMY OF MANAGEMENT JOURNAL 1568-1593 (1996).

Bertrand, Marianne and Sendhil Mullainathan, Agents With and Without Principals, 90 AMERICAN ECONOMICS REVIEW 203-208 (2000).

Bertrand, Marianne and Sendhil Mullainathan, Do CEOs Set Their Own Pay? The Ones Without Principals Do, NBER Working Paper 7604 (2000). 
Bertrand, Marianne and Sendhil Mullainathan, Executive Compensation and Incentives: The Impact of Takeover Legislation, NBER Working Paper 6830 (1998).

Bertsch, Kenneth A., Rachel Leahey, and Harvie Haun, The Structure and Compensation of Boards of Directors at SandP Super 1500 Companies, in BOARD PRACTICES, Investor Responsibility Research Center (1998).

Bizjak, John M., James A. Brickley, and Jeffrey L. Coles, Stock-Based Incentive Compensation and Investment Behavior, 16 JOURNAL OF ACCOUNTING AND ECONOMICS 349-372 (1993).

Bizjak, John M., Michael L. Lemmon and Lalitha Naveen, Has the Use of Peer Groups Contributed to Higher Levels of Executive Compensation? Working Paper, Portland State University, University of Utah and Arizona State University (2000).

Blair, Margaret M. and Lynn A. Stout, Trust Trustworthines, ad the Behavioural Foundations of Corporate Law 149 UNIVERSITY OF PENNSYLVANIA LAW REVIEW 1735-1810 (2001).

Boeker, Warren, Power and Managerial Dismissal: Scapegoating at the Top, 37 ADMINISTRATIVE SCIENCE QUARTERLY 400-418 (1992).

Bogus, Carl T., Excessive Executive Compensation and the Failure of Corporate Democracy, 41 Buffalo LaW RevieW 1-79 (1993).

Boschen, John F. and Kimberly J. Smith, You Can Pay Me Now and You Can Pay Me Later: The Dynamic Response of Executive Compensation to Firm Performance, 68 JOURNAL OF BUSINESS 577-608 (1995).

Brenner, Menachem, Rangarajan K. Sundaram, and David Yermack, Altering the Terms of Executive Stock Options, 57 Journal OF FinANCIAL ECONOMICs 103128 (2000).

Brookfield, David and Phillip Ormrod, Executive Stock Options: Volatility, Managerial Decisions, and Agency Costs, 10 JOURNAL OF MulTINATIONAL FINANCIAL MANAGEMENT 275-95 (2000).

Brudney, Victor, The Independent Director - Heavenly City or Potemkin Village? 95 HARVARD LAW REVIEW 597-659 (1982). 
Campbell, Tim S., Yuk-Shee Chan, and Anthony M. Marino, Incentive Contracts for Managers Who Discover and Manage Investment Projects, 12 JOURNAL OF ECONOMIC BEHAVIOR AND ORGANIZATION 353-364 (1989).

Carpenter, Jennifer N., The Exercise and Valuation of Executive Stock Options, 48 JOURNAL OF FINANCIAL ECONOMICS 127-158 (1998).

Carpenter, Jennifer N. and David L. Yermack, Dilution from Stock-Based Compensation, Working Paper, New York University (2000).

Carpenter, Jennifer N. and David L. Yermack, EXeCuTIVE CoMPENSATION AND Shareholder VAlue: TheORY AND Evidence (Kluwer Academic Publishers: Boston, MA) (1999).

Carroll, Thomas M. and David H. Ciscel, The Effects of Regulation on Executive Compensation, 64 REVIEW OF ECONOMICS AND STATISTICS 505-509 (1982).

Chauvin, Keith W. and Cathy Shenoy, Stock Price Decreases Prior to Executive Stock Option Grants, 7 JOURNAL OF CORPORATE FINANCE: CONTRACTING, GOVERNANCE AND ORGANIZATION 53-76 (2001).

Chidambaran, Nemmara K. and N. Prabhala, Executive Stock Option Repricing, Internal Governance Mechanisms, and Management Turnover, JOURNAL OF FINANCIAL ECONOMICS, forthcoming.

Chance, Don M., Raman Kumar, and Rebecca B. Todd, The 'Repricing' of Executive Stock Options, 57 JOURNAL OF FINANCIAL ECONOMICs 129-154 (2000).

Choe, Chongwoo, Executive Stock Options and Investment Choice, Working Paper, La Trobe University (1999).

Clark, Robert C., Corporate Law (Little, Brown and Company: Boston) (1986).

Coffee, Jr. John C., Do Norms Matter? A Cross-Country Evaluation 149 UNIVERSITY OF PenNSYlvania LaW ReVIEW 2151-2178 (2001).

Conyon, Martin J., Corporate Governance and Executive Compensation, 15 INTERNATIONAL JOURNAL OF INDUSTRIAL ORGANIZATION 493-509 (1997).

Cooter, Robert, and Melvin A. Eisenberg, Fairness, Character, and Efficiency in Firms, 149 UNIVERSITY OF PENNSYLVANIA LAW REVIEW 1717-1734 (2001). 
Core, John E. and Wayne Guay, When Contracts Require Risk-Averse Executives to Hold Equity: Implications for Option Valuation and Relative Performance Evaluation, Working Paper, University of Pennsylvania, The Wharton School (2001).

Core, John E., Wayne Guay, and Robert E. Verrecchia, Are Performance Measures Other Than Price Important to CEO Incentives? Working Paper, University of Pennsylvania (2000).

Core, John E., Robert W. Holthausen, and David F. Larcker, Corporate Governance, Chief Executive Officer Compensation, and Firm Performance, 51 JOURNAL OF FINANCIAL ECONOMICS 371-406 (1999).

Coughlan, Anne T. and Ronald M. Schmidt, Executive Compensation, Management Turnover, and Firm Performance: An Empirical Investigation, 7 JOURNAL OF ACCOUNTING AND ECONOMICS 43-66 (1985).

Cowherd, Douglas M. and David I. Levine, Product Quality and Pay Equity Between Lower-Level Employees and Top Management: An Investigation of Distributive Justice Theory, 37 AdMINISTRATIVE SCIENCE QuARTERLY 302-320 (1992).

Crawford, Anthony J., John R. Ezzell, and James A. Miles, Bank CEO PayPerformance Relations and the Effects of Deregulation, 68 JOURNAL OF BUSINESS 231-256 (1995).

Crystal, Graef S., In Search of Excess: The Overcompensation of American Executives (Norton: New York) (1991).

Cyert, Richard, Sok-Hyon Kang, Praveen Kumar, and Anish Shah, Corporate Governance, Ownership Structure, and CEO Compensation, Working Paper, Carnegie Mellon University and University of Houston (1997).

DeFusco, Richard A., Robert R. Johnson, and Thomas S. Zorn, The Effect of Executive Stock Option Plans on Stockholders and Bondholders, 45 JOURNAL OF FINANCE 617-627 (1990).

DeFusco, Richard A., Thomas S. Zorn, and Robert R. Johnson, The Association Between Executive Stock Option Plan Changes and Managerial Decision Making, 20 FinANCIAL MANAGEMENT 36-43 (1991).

Denis, David J. and Diane K. Denis, Performance Changes Following Top Management Dismissals, 50 THE JOURNAL OF FinANCE 1029-1057 (1995).

Dye, Ronald A., The Trouble with Tournaments, 22 ECONOMIC INQUIRY 147-149 (1984). 
Dye, Ronald A., Relative Performance Evaluation and Project Selection, 30 JOURNAL OF ACCOUNTING RESEARCH 27-52 (1984).

Easterbrook, Frank H., Managers' Discretion and Investors' Welfare: Theories and Evidence, 9 DELAWARE JoURNAL OF CORPORATE LAW 540-571 (1984).

Eaton, Jonathan and Harvey S. Rosen, Agency Delayed Compensation and the Structure of Executive Remuneration, 39 JOURNAL OF FINANCE 1489-1505 (1984).

Eisenberg, Melvin A., The Compensation of Chief Executive Officers and Directors of Publicly Held Corporations, $7^{\text {th }}$ Annual Corporate Governance Institute, (ALIABA) (1999).

Eisenberg, Melvin A., Corporate Law and Social Norms, 99 Columbia LaW ReVIEW 1253-1292 (1999).

Eriksson, Tor and Mette Lausten, Managerial Pay and Firm Performance - Danish Evidence, 16 SCANDINAVIAN JOURNAL OF MANAGEMENT 269-286 (2000).

Evans, Robert and John Evans, The Influence of Non-Executive Director Control and Rewards on CEO Remuneration: Australian Evidence, Working Paper, Curtin University of Technology (2001).

Fama, Eugene F., Agency Problems and the Theory of the Firm, 88 Journal OF POLITICAL ECONOMY 288-307 (1980).

Fama, Eugene F. and Michael C. Jensen, Separation of Ownership and Control, 26 JOURNAL OF LAW AND ECONOMICS 301-325 (1983).

Fee, C. Edward and Charles J. Hadlock, Raids, Rewards, and Reputations in the Market for CEO Talent, Working Paper, Michigan State University (2001).

Fischel, Daniel R., The Race to the Bottom Revisited: Reflection on Recent Development in Delaware's Corporation Law, 76 NORTHWESTERN UNIVERSITY LAW REVIEW 913945 (1982).

Fich, Eliezer M. and Lawrence J. White, Why Do CEO's Reciprocally Sit on Each Other's Boards? New York University Center for Law and Business Working Paper \#CLB-01-002 (2001).

Fried, Jesse M., Insider Signaling and Insider Trading with Repurchase Tender Offers, 67 UNIVERSITY OF CHICAGO LAW REVIEW 421-477 (2000). 
Fried, Jesse M., Reducing the Profitability of Corporate Insider Trading through Pretrading Disclosure, 71 SOUTHERn CALIFORNIA LAW REVIEW 303-392 (1998).

Garen, John E., Executive Compensation and Principal-Agent Theory, 102 JOURNAL OF POLITICAL ECONOMY 1175-1199 (1994).

Garvey, Gerald T. and Gordon Hanka, Capital Structure and Corporate Control: The Effect of Antitakeover Statutes on Firm Leverage, 54 JOURNAL OF FINANCE 519-546 (1999).

Garvey, Gerald T. and Amin Mawani, Executive Stock Options and the Mediation of Stockholder-Bondholder Conflicts, Working Paper, University of British Columbia (1999).

Gay, Christopher, Hard to Lose: Options Promote Stock Ownership Among Executives: But Critics Say They're A Lot More Costly Than Shareholders Realize, WALL STREET JOURNAL, Apr.8, 1999 at R6.

Gibbons, Robert, Incentives and Careers in Organizations, in ADVANCES IN ECONOMIC THEORY AND ECONOMETRICS 1-37 (D. Kreps and and K. Wallis, eds.) Cambridge University Press (1997).

Gibbons, Robert and Kevin J. Murphy, Does Executive Compensation Affect Investment? 5 JOURNAL OF APPLIED CORPORATE FINANCE 99-109 (1992).

Gibbons, Robert and Kevin J. Murphy, Relative Performance Evaluation for Chief Executive Officers, 43 INDUSTRIAL AND LABOR RELATIONS REVIEW 30-51 (1990).

Gibbons, Robert and Michael Waldman, Careers in Organizations: Theory and Evidence, in 3 HANDBOOK OF LABOR ECONOMICS 2374-2437 (O. Ashenfelter and D. Card, eds.) North Holland: Amsterdam (1998).

Gilson, Stuart C., Management Turnover and Financial Distress, 25 JouRNAL OF FINANCIAL ECONOMICS 241-262 (1989).

Gilson, Stuart C. and Michael R. Vetsuypens, CEO Compensation in Financially Distressed Firms: An Empirical Analysis, 48 JouRnAl OF FINANCE 425-458 (1993).

Goolsbee, Austan, It's Not About the Money: Why Natural Experiments Don't Work on the Rich, in Does Atlas SHRUG? THE ECONOMIC CONSEQUENCES OF TAXING THE RICH (J. Slemrod, ed.) (Russell Sage Foundation and Harvard University Press: Cambridge, MA) (2000). 
Goolsbee, Austan, What Happens When You Tax the Rich? Evidence from Executive Compensation, 108 JOURNAL OF POLITICAL ECONOMY, 352-378 (2000).

Grossman, Sanford J. and Oliver D. Hart, An Analysis of the Principal-Agent Problem, 51 ECONOMETRICA 7-45 (1983).

Groves, Ronald L., EXECUTIVE COMPENSATION (Commerce Clearing House: Chicago) (1992).

Habib, Michel A. and Alexander P. Ljungqvist, Firm Value and Managerial Incentives, Working Paper, London Business School and New York University (2000).

Hadlock, Charles J. and Gerald B. Lumar, Compensation, Turnover, and Top Management Incentives: Historical Evidence, 70 JOURNAL OF BUSINESS 153-187 (1997).

Hall, Brian J., The Pay to Performance Incentives of Executive Stock Options, NBER Working Paper 6674 (1998).

Hall, Brian J. and Jeffrey B. Leibman, Are CEO's Really Paid Like Bureaucrats? 113 THE QUARTERLY JOURNAL OF ECONOMICS 653-691 (1998).

Hall, Brian J., A Better Way to Pay CEO's? in 35 EXeCUTIVE COMPENSATION AND SHAREHOLDER VAlUE (J. Carpenter and D. Yermack, eds.) (1999).

Hall, Brian J. and Jeffrey B. Liebman, The Taxation of Executive Compensation, NBER Working Paper 7596 (2000).

Hall, Brian J. and Kevin J. Murphy, Stock Options for Undiversified Executives, Working paper, Harvard Business School (2000).

Hallock, Kevin, Reciprocally Interlocking Boards of Directors and Executive Compensation, 32 JOURNAL OF FINANCIAL AND QUANTITATIVE ANALYSIS 331-334 (1997).

Hallock, Kevin, Dual Agency: Corporate Boards with Reciprocally Interlocking Relationships, in EXECUTIVE COMPENSATION AND SHAREHOLDER VAlUE 55-75 (J. Carpenter and D. Yermack, eds.) (Kluwer Academic Publishers) (1999).

Hallock, Kevin and Kevin J. Murphy, THE ECONOMiCs of EXeCUTIVE COMPENSATION (Edward Elgar Publishing Limited: Northampton, MA) (1998). 
Hambrick, Donald C. and Albert A. Cannella Jr., Relative Standing: A Framework for Understanding Departures of Acquired Executives, 36 ACADEMIC MANAGEMENT JOURNAL 733-762 (1993).

Hartzell, Jay C. and Laura T. Starks, Institutional Investors and Executive Compensation, Working Paper, New York University and University of Texas (2000).

Haubrich, Joseph G., Risk Aversion, Performance Pay, and the Principal-Agent Problem, 102 JOURNAL OF POlitical ECONOMICs 258-276 (1994).

Hemmer, Thomas, Steve Matsunaga, and Terry Shevlin, Optimal Exercise and the Cost of Granting Employee Stock Options with a Reload Provision, JOURNAL OF ACCOUNTING RESEARCH 231-255 (1998).

Hemmer, Thomas, Steve Matsunaga, and Terry Shevlin, Reload Employee Stock Option Plans: Incentive Alignment or Rent Extraction, 15 JOURNAL OF ACCOUNTING, AUdiTING, AND FINANCE 393-423 (2000).

Hermalin, Benjamin E. and Michael S. Weisbach, Boards of Directors as an Endogenously Determined Institution: A Survey of the Economic Literature, NBER Working Paper 8161 (2001).

Hermalin, Benjamin E. and Michael S. Weisbach, The Determinants of Board Composition, 19 RAND JOURNAL OF ECONOMICS 589-606 (1988).

Hermalin, Benjamin E. and Michael S. Weisbach, Endogenously Chosen Boards of Directors and Their Monitoring of the CEO, 88 AMERICAN ECONOMIC REVIEW 96118 (1998).

Himmelberg, Charles P. and R. Glenn Hubbard, Incentive Pay and the Market for CEOs: An Analysis of Pay for Performance Sensitivity, Working Paper, Columbia University and the National Bureau of Economic Research (1999).

Himmelberg, Charles P., R. Glenn Hubbard, and Darius Palia, Understanding the Determinants of Managerial Ownership and the Link Between Ownership and Performance, 53 Journal OF FinANCIAL ECONOMICs 353-384 (1998).

Holmstrom, Bengt, Contracts and the Market for Executives: Comment, in CONTRACT ECONOMICS (Lars Wein and Hans Wijknader, eds.) (Blackwell: Cambridge, MA) (1992).

Holmstrom, Bengt, Moral Hazard and Observability, 10 BeLL JOURNAL ECONOMICS 7491 (1979). 
Holmstrom, Bengt, Moral Hazard in Teams, 13 Bell Journal OF ECONOMICs 324-340 (1982).

Holmstrom, Bengt and Paul Milgrom, Multitask Principal-Agent Analyses, Incentive Contracts, Asset Ownership, and Job Design, 7 JOURNAL OF LAW, ECONOMICS AND ORGANIZATION 24-52 (1991).

Hubbard, R. Glen and Darius Palia, Executive Pay and Performance: Evidence from the US Banking Industry, 39 JOURNAL OF FINANCIAL ECONOMICS 105-130 (1995).

Huddart, Steven and Mark Lang, Employee Stock Options Exercises: An Empirical Analysis, 21 JOURNAL OF ACCOUNTING AND ECONOMICs 5-43 (1996).

Huson, M., Robert Parrino, and Laura Starks, THE EFFECTIVENESS OF INTERNAL MONITORING MECHANISMS: EVIDENCE FROM CEO TURNOVER BETWEEN 1971 AND 1994, Working Paper No. 6-97, Institute For Financial Research (1998).

Janakiraman, Surya N., Richard A. Lambert, and David F. Larcker, An Empirical Investigation of the Relative Performance Evaluation Hypothesis, 30 JOURNAL OF ACCOUNTING RESEARCH 53-69 (1992).

Jensen, Michael C., The Modern Industrial Revolution, Exit and the Failure of Internal Control Systems, 48 JournAL OF FINANCE 831-880 (1993).

Jensen, Michael and Kevin J. Murphy, CEO Incentives: It's Not How Much, But How, HARVARD BUSINESS REVIEW 138-153 (1990).

Jensen, Michael and Kevin J. Murphy, Performance Pay and Top-Management Incentives, 98 JourNAL OF POLITICAL ECONOMY 225-264 (1990).

Jensen, Michael and J. Zimmerman, Management Compensation and the Managerial Labor Market, 7 JOURNAL OF ACCOUNTING AND ECONOMICS 3-9 (1985).

Jenter, Dirk C., Understanding High-Powered Incentives, (working paper, 2001).

Jereski, L., Share the Wealth: As Options Proliferate, Investors Question Effect on Bottom Line, WALL STREET JOURNAL, Jan.14, 1997, at A1.

Jin, Li, CEO Compensation, Diversification and Incentives, Working Paper, Massachusetts Institute of Technology (2000).

Jin, Li, CEO Compensation, Risk Sharing and Incentives: Theory and Empirical Results, Working Paper, Massachusetts Institute of Technology (2000). 
Johnson, Marilyn F., Susan Porter, and Margaret B. Shackell, Stakeholder Pressure and the Structure of Executive Compensation, Working Paper, University of Michigan and University of Texas-Austin (1997).

Johnson, Shane and Yisong S. Tian, Indexed Executive Stock Options, 57 JouRNAL OF FINANCIAL ECONOMICS 35-64 (2000).

Johnson, Shane and Yisong S. Tian, The Value and Incentive Effects of Non-Traditional Executive Stock Option Plans, 57 Journal OF FinANCIAL ECONOMICs 3-34 (2000).

Jones, Derek and Takao Kato, The Determinants of Chief Executive Compensation in Transitional Economies: Evidence from Bulgaria, 3 JOURNAL OF LABOR ECONOMICS 319-336 (1996).

Joskow, Paul L. and Nancy L. Rose, CEO Pay and Firm Performance: Dynamics, Asymmetries, and Alternative Performance Measures, NBER Working Paper 4976 (1994).

Joskow, Paul, Nancy L. Rose, and Catherine D. Wolfram, Political Constraints on Executive Compensation: Evidence from the Electric Utility Industry, 27 RAND JOURNAL OF ECONOMICS 165-182 (1996).

Joskow, Paul, Nancy L. Rose, and Andrea Shepard, Regulatory Constraints on CEO Compensation, Brookings Papers: Microeconomics (1993).

Kahan, Marcel, The Limited Significance of Norms for Corporate Governance, 149 UNIVERSITY OF PENNSYLVANIA LAW REVIEW 1869-1900 (2001).

Kang, Jun-Koo and Anil Shivdasani, Firm Performance, Corporate Governance, and Top Executive Turnover in Japan, 38 JOURNAL OF FINANCIAL ECONOMICs 29-58 (1995)

Kaplan, Steven N., Top Executive Rewards and Firm Performance: A Comparison of Japan and the United States, 102 JourNal OF POLITICAL ECONOMY 510-546 (1994).

Kaplan, Steven N., Top Executives, Turnover, and Firm Performance in Germany, 10 JOURNAL OF LABOR ECONOMICS AND ORGANIZATION 142-159 (1994).

Kato, Takao and Mark Rockel, Experiences, Credentials, and Compensation in the Japanese and US Managerial Labor Markets: Evidence from New Micro Data, 6 JOURNAL OF THE JAPANESE AND INTERNATIONAL ECONOMIES 30-51 (1992). 
Kole, Stacey R., The Complexity of Compensation Contracts, 43 JOURNAL OF FINANCIAL ECONOMICS 79-104 (1997).

Lambert, Richard A., David F. Larcker, and Robert E. Verrecchia, Portfolio Considerations in Valuing Executive Compensation, 29 JOURNAL OF ACCOUNTING RESEARCH 129-149 (1991).

Lazear, Edward P., Output-based Pay: Incentives or Sorting, NBER Working Paper 7419 (1999).

Lazear, Edward P. and Sherwin Rosen, Rank-Order Tournaments as Optimum Labor Contracts, 89 JOURNAL OF POLITICAL ECONOMY 841-864 (1981).

Leonard, Jonathan S., Executive Pay and Firm Performance, 43 INDUSTRIAL AND LABOR RELATIONS REVIEW 13-29 (1990).

Levmore, Saul, Puzzling Stock Options and Compensation Norms, 149 UNIVERSITY OF PENNSYlVANIA LAW REVIEW 1901-1940 (2001).

Loderer, Claudio and Kenneth Martin, Executive Stock Ownership and Performance: Tracking Faint Traces, 45 JOURNAL OF FINANCIAL ECONOMICS 223-255 (1997).

Lorsch, Jay W. and Elizabeth M. MacIver, PAWNS OR POTENTATES? THE REALITY OF AMERICA's CORPORATE BOARDS (Harvard Business School Press: Boston) (1989).

Loewenstein, Mark J., Reflections of Executive Compensation and a Modest Proposal for (Further) Reform, 50 SOUTHERn METHODIST UNIVERSITY LAW REVIEW 201-223 (1996).

Lublin, Joanne S., Pay for Outperforming: James Crowe, Chief of Level 3 Communications, Makes the Case for Linking Stock Options to Market-Beating Gains, WALL STREET JOURNAL, April 6, 2000, at R8.

Main, Brian G. M., Charles A. O'Reilly III, and James Wade, The CEO, the Board of Directors, and Executive Compensation: Economic and Psychological Perspectives, 11 INDUSTRIAL AND CORPORATE CHANGE 293-332 (1995).

Mahoney, Paul G., and Chris W. Sanchirico, Competing Norms and Social Evolution: Is the Fittest Norm Efficient? 149 UNIVERSITY OF PENNSYLVANIA LAW REVIEW 20272062 (2001).

Manne, Henry G., Mergers and the Market for Corporate Control, 73 JouRnAL OF POLITICAL ECONOMY 110 (1965). 
Matsunaga, Steven R., The Effects of Financial Reporting Costs on the Use of Employee Stock Options, 70 THe AcCounting Review 1-26 (1995).

Matsunaga, Steve, Terry Shevlin, and D. Shores, Disqualifying Dispositions of Incentive Stock Options: Tax Benefits Versus Financial Reporting Costs, 30 JOURNAL OF ACCOUNTING RESEARCH SUPPLEMENT 37-68 (1992).

McConnell, John J. and Henri Servaes, Additional Evidence on Equity Ownership and Corporate Value, 27 JOURNAL OF FINANCIAL ECONOMICS 596-612 (1990).

Mehran, Hamid, George E. Nogler, and Kenneth B. Schwartz, CEO Incentive Plans and Corporate Liquidation Policy, 50 JOURNAL OF FinANCIAL ECONOMICs 319-349 (1998).

Meulbroek, Lisa K., The Efficiency of Equity-Linked Compensation: Understanding the Full Cost of Awarding Executive Stock Options, Working Paper, Harvard Business School (2000).

Meulbroek, Lisa K., Executive Compensation Using Relative-Performance-Based Options: Evaluating the Structure and Costs of Indexed Options, Working Paper, Harvard Business School ( 2001).

Mikkelson, Wayne H. and M. Megan Partch, The Decline of Takeovers and Disciplinary Turnover, 44 JOURNAL OF FINANCIAL ECONOMICS 205-228 (1997).

Milhaupt, Curtis J., Creative Norm Destruction: The Evolution of Nonlegal Rules in Japanese Corporate Governance 149 UnIVERSITY OF PENNSYLVANIA LAW REVIEW 2083-2130 (2001).

Miller, Merton and Myron Scholes, Executive Compensation, Taxes, and Incentives, in FINANCIAL ECONOMICS: THEORY AND APPLICATION 179-200 (1981).

Mirrlees, James A., The Optimal Structure of Incentives and Authority within an Organization, 7 BELL JOURNAL OF ECONOMICS 105-131 (1976).

Mishra, Chandrasekhar and James F. Nielsen, Board Independence and Compensation Policies in Large Bank Holding Companies, 29 FinANCIAL MANAGEMENT 51-70 (2000).

Mookherjee, Dilip, Optimal Incentives Schemes with Many Agents, 51 THE ReVIEW OF ECONOMIC STUDIES 433-446 (1984). 
Morck, Randall, Andrei Shleifer, and Robert W. Vishny, Management Ownership and Market Valuation: An Empirical Analysis, 20 JOURNAL OF FinANCIAL ECONOMICS 293-316 (1988).

Murphy, Kevin J., Corporate Performance and Managerial Remuneration: An Empirical Analysis, 7 JOURNAL OF ACCOUNTING AND ECONOMICs 11-42 (1985).

Murphy, Kevin J., Executive Compensation, in HANDBOOK OF LABOR ECONOMICS (Orley Ashenfelter and David Card eds.) (North Holland: Amsterdam) (1999).

Murphy, Kevin J., Performance Standard in Incentive Contracts, 30 Journal OF ACCOUNTING AND ECONOMICS 245-278 (2000).

Nohel, Tom and Steven Todd, Executive Compensation, Managerial Risk Aversion, and the Choice of Risky Projects, Working Paper, Loyola University-Chicago (2000).

Nohel, Tom and Steven Todd, Executive Compensation, Reputation, and Risk-Taking Incentives, Working Paper, Loyola University-Chicago (2001).

Nohel, Tom and Steven Todd, Optimal Compensation for Risk-Averse Executives with Career Concerns, Working Paper, Loyola University-Chicago (2001).

Ofek, Eli and David Yermack, Taking Stock: Does Equity-Based Compensation Increase Managers' Ownership? 55 JOURNAL OF FINANCE 1367-1384 (1997).

O'Reilly, Charles A., James Wade, and Tim Pollock, Overpaid CEO's and Underpaid Managers: Equity and Executive Compensation, Working Paper, Stanford University and University of Illinois at Urbana-Champaign (1998).

Perry, Tod and Marc Zenner, Pay for Performance? Government Regulation and the Structure of Compensation Contracts, Working Paper, Arizona State University and The University of North Carolina at Chapel Hill (1997).

Perry, Tod and Marc Zenner, CEO Compensation in the 1990's: Shareholder Alignment or Shareholder Expropriation? 35 THE WAKE FOREST LAW REVIEW 142-144 (2000).

Rajgopal, Shivaram and Terry Shevlin, Early Evidence on the Informativeness of the SEC's Market Risk Disclosures: The Case of Commodity Price Risk Exposure of Oil and Gas Producers, 74 AcCOUNTING RevieW 251-80 (1999).

Rappaport, Alfred, New Thinking on How to Link Executive Pay with Performance, HARVARD BusINESS REVIEW, Mar-Apr.1999, 91-101. 
Rock, Edward B. and Michael L. Wachter, Islands of Conscious Power: Laws, Norms, and the Self-Governing Corporation 149 UNIVERSITY OF PENNSYLVANIA LAW REVIEW 1619-1700 (2001).

Roe, Mark J. The Shareholder Wealth Maximization Norm and Industrial Organization 149 UnIVERSITY OF PENNSYLVANIA LAW REVIEW 2063-2082 (2001).

Reingold, Jennifer L., Nice Option If You Can Get It, Business WeEK, May 4, 1998, at 111.

Rose, Nancy and Andrea Shepard, Firm Diversification and CEO Compensation: Managerial Ability or Executive Entrenchment? 28 RAND JOURNAL OF ECONOMICS 489-514 (1994).

Rosen, Sherwin, Authority, Control, and the Distribution of Earnings, 13 BELL JOURNAL OF ECONOMICS 311-323 (1982).

Rosen, Sherwin, Contracts and the Market for Executives, in 1 THE ECONOMICs OF EXECUTIVE COMPENSATION 182-211 (Kevin J. Hallock and Kevin J. Murphy, eds.) (Edward Elgar Publishing: Northampton, MA) (1992).

Rosenstein, Stuart and Jeffrey G. Wyatt, Outside Directors, Board Independence, and Shareholder Wealth, 26 JOURNAL OF FINANCIAL ECONOMICS 175-191 (1990).

Ross, Stephen A., The Determination of Financial Structure: The Incentive-Signaling Approach, 8 BELL JOURNAL OF ECONOMICS 23-40 (1977).

Roulstone, Darren T., The Relation Between Insider-Trading Restrictions and Executive Compensation, Working Paper, University of Chicago (2001).

Ruxton, Kathy B., EXeCutive PAY, 1997 : ChIEF EXECUTIVE OfFICER COMPENSATION AT SANDP SUPER 1,500 COMPANIES As REPORTED IN 1997 Investor Responsibility Research Center, Incorporated (1998).

Ryan Jr., Harley, E. and Roy A. Wiggens III., The Influence of Firm- and ManagerSpecific Characteristics on the Structure of Executive Compensation, 7 JOURNAL OF CORPORATE FINANCE 101-123 (2001).

Saly, P. Jane, Repricing Executive Stock Options in a Down Market, 16 JouRnAL OF ACCOUNTING AND ECONOMICS 325-356 (1994).

Saly, P. Jane, Ravi Jagannathan, and Steven J. Huddart, Valuing the Reload Feature of Executive Stock Options, 12 AccounTING HORIzONS 219-240 (1999). 
Schizer, David, Executives and Hedging: The Fragile Legal Foundation of Incentive Compatibility, 100 Columbia Law Review 440-504 (2000).

Schizer David, M., Tax Constraints on Indexed Options 149 UNIVERSITY OF PenNSYlVANia LaW RevieW 1941-1954 (2001).

Schrand, Catherine and Haluk Unal, Hedging and Coordinated Risk Management: Evidence from Thrift Conversions, 53 JOURNAL OF FINANCE 979-1014 (1998).

Shivdasani, Anil and David Yermack, CEO Involvement in the Selection of New Board Members: An Empirical Analyis, 54 JoURNAL OF FINANCE 1829-1853 (1999).

Skeel, Jr., David A., Shaming in Corporate Law 149 University OF PENNSYLVANIA LAW REVIEW 1811-1868 (2001).

Smith Jr., Clifford W., and Ross L. Watts, Incentive and Tax Effects of Executive Compensation Plans, 7 Australian Journal OF MANAGEMENT 139-157 (1982).

Statement of Financial Accounting Standards No. 123: Accounting for Stock-Based Compensation, Financial Accounting Standards Board (1995).

Strickland, Deon, Kenneth W. Wiles, and Marc Zenner, A Requiem for the USA: Is Small Shareholder Monitoring Effective? 40 JOURNAL OF FINANCIAL ECONOMICS 319-338 (1996).

Thomas, Randall, S. and Kenneth J. Martin, Litigating Challenges to Executive Pay: An Exercise in Futility? forthcoming WASHINGTON UNIVERSITY LAW QUARTERLY (2001).

Tian, Yisong S., Optimal Contracting, Incentive Effects and the Valuation of Executive Stock Options, Working Paper, York University (2001).

Tosi Jr., Henry L. and Luis R. Gomez-Mejia, The Decoupling of CEO Pay and Performance: An Agency Theory Perspective, 34 ADMINISTRATIVE SCIENCE QUARTERLY 169-189 (1989).

Tosi Jr., Henry L. and Luis R. Gomez-Mejia, CEO Compensation Monitoring and Firm Performance, 37 ACADEMY OF MANAGEMENT JouRnAl 1002-1016 (1994).

Tufano, Peter A., Who Manages Risk? An Empirical Examination of Risk Management Practices in the Gold Mining Industry, 51 JOURNAL OF FINANCE 1097-1137 (1996).

Vagts, Detlev., Challenges to Executive Compensation: For the Markets or the Courts?, 8 JOURNAL OF CORPORATION LAW 231-275 (1983). 
Veasey, E. Norman, Should Corporation Law Inform Aspirations for Good Corporate Governance Practices - or Vice Versa? 149 UnIVERSITY OF PENNSYLVANIA LAW REVIEW 2279-2191 (2001).

Wade, James B., Joseph F. Porac, and Timothy G. Pollock, Worth, Words, and the Justification of Executive Pay, 18 Journal OF ORGANIZATIONAL BEHAVIOR 641664 (1997).

Warner, Jerold B., Ross L. Watts, and Karen H. Wruck, Stock Prices and Top Management Changes, 20 JouRnAL OF FinANCIAL ECONOMICs 461-492 (1988)

Weisbach, Michael S., Outside Directors and CEO Turnover, 20 JouRnAL OF FINANCIAL ECONOMICS 431-460 (1988).

Yablon, Charles M., Bonus Questions--Executive Compensation in the Era of Pay for Performance, 75 Notre Dame LAW Review 271-307 (1999).

Yermack, David, Do Corporations Award CEO Stock Options Effectively? 39 JOURNAL OF FINANCIAL ECONOMICS 237-269 (1995).

Yermack, David, Good Timing: CEO Stock Option Awards and Company News Announcements, 52 JoURNAL OF FINANCE 449-477 (1997).

Yermack, David, Higher Market Valuation of Companies With a Small Board of Directors, 40 JOURNAL OF FinANCIAL ECONOMICS 185-211 (1996).

Zhou, Xianming, CEO Pay, Firm Size, and Corporate Performance: Evidence from Canada 33 CANADIAN JOURNAL OF ECONOMICS 213-251 (1997). 